Prepared in cooperation with the South Carolina Department of Health and Environmental Control

\title{
Low-Flow Frequency and Flow Duration of Selected South Carolina Streams in the Savannah and Salkehatchie River Basins Through March 2014
}

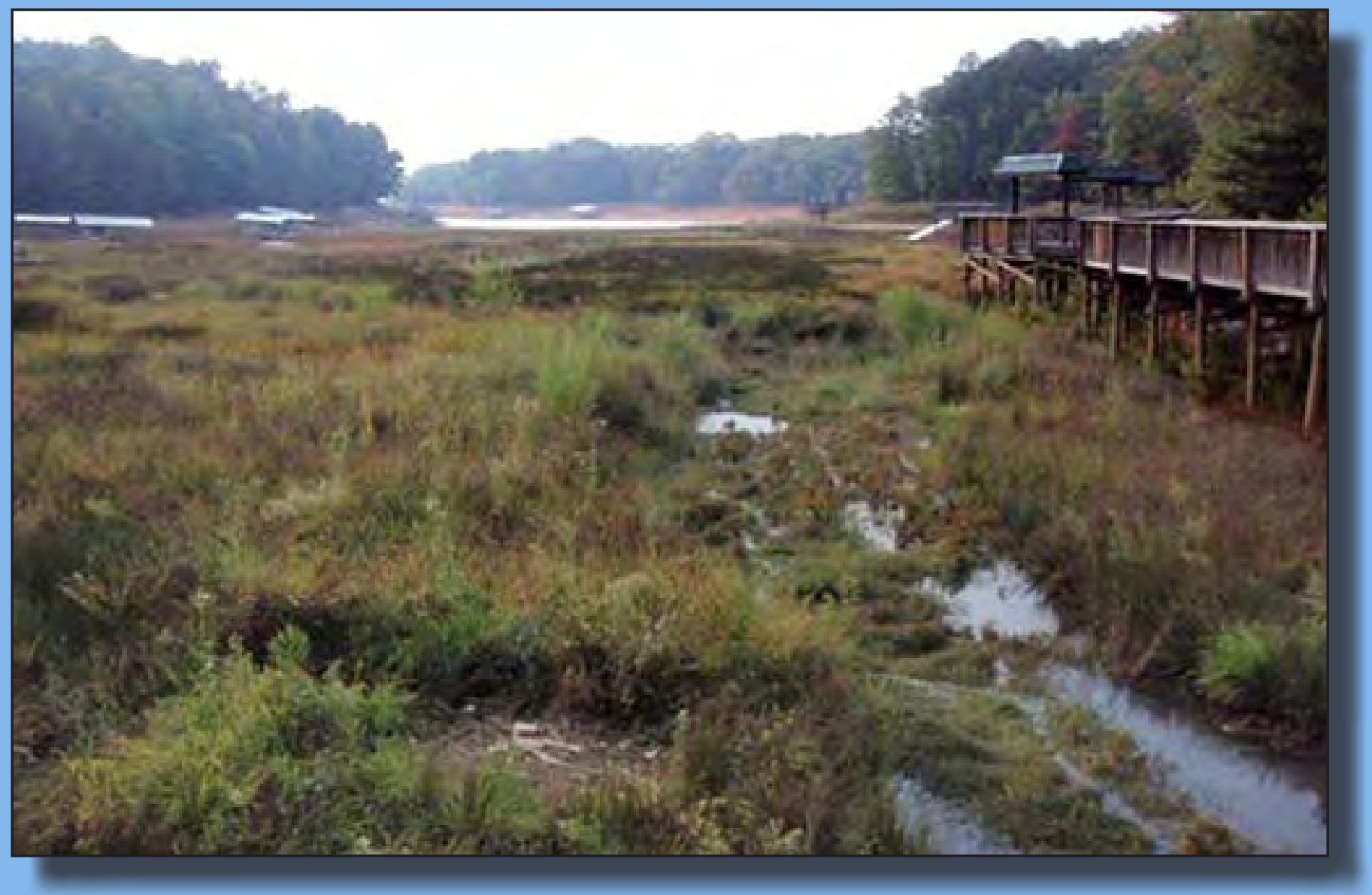

Open-File Report 2016-1101

U.S. Department of the Interior U.S. Geological Survey 
Front and back covers: Lake Hartwell from the Larry Abernathy Waterfront Park boardwalk in Clemson, S.C., during a period of drought on October 7, 2008 (front) and near full-pool elevation on May 23, 2016 (back). Photographs by Toby Feaster, U.S. Geological Survey 


\section{Low-Flow Frequency and Flow Duration of Selected South Carolina Streams in the Savannah and Salkehatchie River Basins Through March 2014}

By Toby D. Feaster and Wladmir B. Guimaraes

Prepared in cooperation with the South Carolina Department of Health and Environmental Control

Open-File Report 2016-1101 


\title{
U.S. Department of the Interior SALLY JEWELL, Secretary
}

\section{U.S. Geological Survey Suzette M. Kimball, Director}

\author{
U.S. Geological Survey, Reston, Virginia: 2016
}

For more information on the USGS - the Federal source for science about the Earth, its natural and living resources, natural hazards, and the environment—visit http://www.usgs.gov or call 1-888-ASK-USGS.

For an overview of USGS information products, including maps, imagery, and publications, visit http://www.usgs.gov/pubprod/.

Any use of trade, firm, or product names is for descriptive purposes only and does not imply endorsement by the U.S. Government.

Although this information product, for the most part, is in the public domain, it also may contain copyrighted materials as noted in the text. Permission to reproduce copyrighted items must be secured from the copyright owner.

Suggested citation:

Feaster, T.D., and Guimaraes, W.B., 2016, Low-flow frequency and flow duration of selected South Carolina streams in the Savannah and Salkehatchie River Basins through March 2014: U.S. Geological Survey Open-File Report 2016-1101, 62 p., http://dx.doi.org/10.3133/ofr20161101.

ISSN 2331-1258 (online) 


\section{Contents}

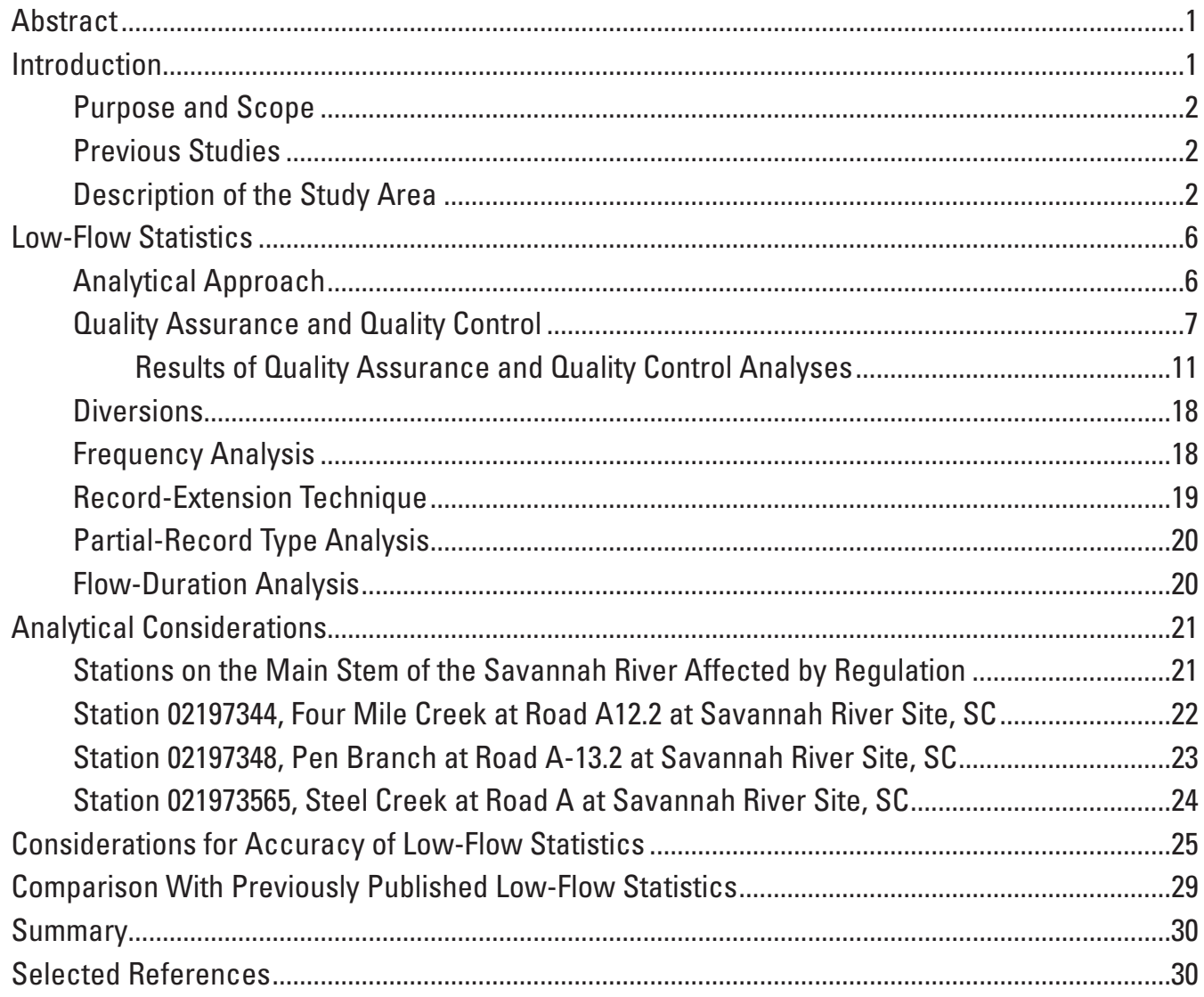

\section{Figures}

1. Map showing the eight major river basins in South Carolina as defined by the South Carolina Department of Health and Environmental Control ................................................

2. Map showing eight-digit hydrologic unit code subbasins, subbasin name, and number of U.S. Geological Survey continuous-record streamgaging stations analyzed for the Savannah and Salkehatchie River Basins of South Carolina............................................4

3-13. Graphs showing-

3. Annual minimum 7-day average streamflow at unregulated U.S. Geological Survey streamgaging stations included in this investigation that indicated a trend for the period analyzed.

4. Total annual statewide precipitation for South Carolina indicating no trend in the period from 1895 to 2014 and, indicating a downward trend in the period from 1960 to 2014.

5. Annual minimum 7-day average streamflow at unregulated U.S. Geological Survey streamgaging stations included in this investigation that indicated no trend for the period analyzed. 
6. Annual minimum 7-day average streamflow at regulated U.S. Geological Survey streamgaging stations included in this investigation that indicated no trends in the data and trends in the data

7. Low-flow frequency curve for the annual minimum 7-day average streamflow for the U.S. Geological Survey streamgaging station 02177000,

Chattooga River near Clayton, GA

8. Daily mean flow at station 02197344, Four Mile Creek at Road A12.2 at Savannah River Site, SC, for the period November 1976 to September 2002............22

9. Daily mean flow at station 02197348, Pen Branch at Road A-13.2 at Savannah River Site, SC, for the period November 1976 to September 2002.

10. Daily mean flow and cumulative daily mean flow for station 021973565 , Steel Creek at Road A at Savannah River Site, SC, for the period March 1985 to September 2002

11. Annual minimum 7-day average streamflow and 7010 estimates at U.S. Geological Survey streamgaging station 02177000, Chattooga River near Clayton, GA.

12. Annual minimum 7-day average streamflow and 7010 estimates from a synthesized dataset where the annual minimum 7-day average streamflows from U.S. Geological Survey streamgaging station 02177000, Chattooga River near Clayton, GA, were reversed for the period of record.

13. Annual minimum 7-day average streamflow and 7010 estimates at U.S. Geological Survey streamgaging station 02177000, Chattooga River near Clayton, GA, for seven 10-year periods: climatic years 1940 to 1949, 1950 to 1959,1960 to 1969,1970 to 1979,1980 to 1989,1990 to 1999 , and 2000 to 2009

\section{Tables}

1. South Carolina Department of Health and Environmental Control (SCDHEC) schedule for basin data analysis and statistics availability.

2. Low-flow statistics for continuous-record streamgaging stations in the Savannah and Salkehatchie River Basins of South Carolina

3. Eight-digit hydrologic unit code subbasins, subbasin name, and number of U.S. Geological Survey continuous-record streamgaging stations analyzed for the Savannah and Salkehatchie River Basins of South Carolina.............................................

4. Major reservoirs in the Savannah River Basin 6

5. Streamgaging stations in the Savannah and Salkehatchie River Basins of South Carolina that were considered for computations of low-flow statistics. . .8

6. Differences between the annual minimum 7-day average streamflow with a 10-year recurrence interval in the current report and previously published values for continuous-record streamgaging stations in the Savannah and Salkehatchie River Basins of South Carolina. 


\section{Conversion Factors}

Inch/Pound to SI

\begin{tabular}{lcl}
\hline \multicolumn{1}{c}{ Multiply } & \multicolumn{1}{c}{ By } & \multicolumn{1}{c}{ To obtain } \\
\hline \multicolumn{2}{c}{ Length } \\
\hline foot $(\mathrm{ft})$ & 0.3048 & meter $(\mathrm{m})$ \\
mile $(\mathrm{mi})$ & 1.609 & kilometer $(\mathrm{km})$ \\
\hline \multicolumn{2}{c}{ Area } & \\
\hline square mile $\left(\mathrm{mi}^{2}\right)$ & 2.590 & square kilometer $\left(\mathrm{km}^{2}\right)$ \\
\hline \multicolumn{3}{c}{ Volume } \\
\hline cubic foot $\left(\mathrm{ft}^{3}\right)$ & 0.02832 & cubic meter $\left(\mathrm{m}^{3}\right)$ \\
acre-foot $($ acre-ft) & 1,233 & cubic meter $\left(\mathrm{m}^{3}\right)$ \\
\hline & \multicolumn{1}{c}{ Flow rate } & \\
\hline cubic foot per second $\left(\mathrm{ft}^{3} / \mathrm{s}\right)$ & 0.02832 & cubic meter per second $\left(\mathrm{m}^{3} / \mathrm{s}\right)$ \\
million gallons per day $(\mathrm{Mgal} / \mathrm{d})$ & 0.04381 & cubic meter per second $\left(\mathrm{m}^{3} / \mathrm{s}\right)$ \\
\hline
\end{tabular}

\section{Datum}

Vertical coordinate information is referenced to the National Geodetic Vertical Datum of 1929 (NGVD 29).

Horizontal coordinate information is referenced to the North American Datum of 1927 (NAD 27) or 1983 (NAD 83). 


\section{Abbreviations}

$\begin{array}{ll}\text { CR } & \text { Continuous record } \\ \text { HUC } & \text { Hydrologic unit code } \\ \text { loratio } & \text { Ratio of the 10th percentile to the 50th percentile of the average 7-day flows } \\ \text { MOVE.1 } & \text { Maintenance of Variance Extension, Type 1 } \\ \text { NPDES } & \text { National Pollutant Discharge Elimination System } \\ \text { NWIS } & \text { National Water Information System } \\ \text { PR } & \text { Partial record } \\ \text { 07 } & \text { Annual minimum 7-day average streamflow } \\ \text { OA0C } & \text { Quality assurance and quality control } \\ \text { SCDNR } & \text { South Carolina Department of Natural Resources } \\ \text { SCDHEC } & \text { South Carolina Department of Health and Environmental Control } \\ \text { SRS } & \text { Savannah River Site } \\ \text { TMDL } & \text { Total maximum daily load } \\ \text { USACE } & \text { U.S. Army Corps of Engineers } \\ \text { USGS } & \text { U.S. Geological Survey } \\ \text { WW0MS } & \text { Watershed Water Quality Management Strategy } \\ \text { 702 } & \text { Annual minimum 7-day average streamflow with a 2-year recurrence interval } \\ \text { 7010 } & \text { Annual minimum 7-day average streamflow with a 10-year recurrence interval }\end{array}$




\title{
Low-Flow Frequency and Flow Duration of Selected South Carolina Streams in the Savannah and Salkehatchie River Basins Through March 2014
}

\author{
By Toby D. Feaster and Wladmir B. Guimaraes
}

\section{Abstract}

An ongoing understanding of streamflow characteristics of the rivers and streams in South Carolina is important for the protection and preservation of the State's water resources. Information concerning the low-flow characteristics of streams is especially important during critical flow periods, such as during the historic droughts that South Carolina has experienced in the past few decades.

In 2008, the U.S. Geological Survey, in cooperation with the South Carolina Department of Health and Environmental Control, initiated a study to update low-flow statistics at continuous-record streamgaging stations operated by the U.S. Geological Survey in South Carolina. This report presents the low-flow statistics for 28 selected streamgaging stations in the Savannah and Salkehatchie River Basins in South Carolina. The low-flow statistics include daily mean flow durations for the 5-, 10-, 25-, 50-, 75-, 90-, and 95-percent probability of exceedance and the annual minimum 1-, 3-, 7-, 14-, 30-, 60-, and 90-day mean flows with recurrence intervals of $2,5,10$, 20,30 , and 50 years, depending on the length of record available at the streamgaging station. The low-flow statistics were computed from records available through March 31, 2014.

Low-flow statistics are influenced by length of record, hydrologic regime under which the data were collected, analytical techniques used, and other factors, such as urbanization, diversions, and droughts that may have occurred in the basin. To assess changes in the low-flow statistics from the previously published values, a comparison of the low-flow statistics for the annual minimum 7-day average streamflow with a 10 -year recurrence interval (7Q10) from this study was made with the most recently published values. Of the 28 streamgaging stations for which recurrence interval computations were made, 14 streamgaging stations were suitable for comparing to low-flow statistics that were previously published in U.S. Geological Survey reports. These comparisons indicated that seven of the streamgaging stations had values lower than the previous values, two streamgaging stations had values higher than the previous values, and two streamgaging stations had values that were unchanged from previous values. The remaining three stations for which previous 7Q10 values were computed, which are located on the main stem of the Savannah River, were not compared with current estimates because of differences in the way the pre-regulation and regulated flow data were analyzed.

\section{Introduction}

Low-flow stream statistics are used by South Carolina State agencies, such as the South Carolina Department of Health and Environmental Control (SCDHEC) and the South Carolina Department of Natural Resources (SCDNR), for many applications, including determining waste-load allocations for point sources, development of total maximum daily loads (TMDLs) for streams, determining the quantity of water that can be withdrawn safely from a particular stream, and preparing the State Water Plan. In addition, low-flow statistics are useful for improving the general level of understanding of natural and regulated stream systems. The droughts of the past few decades in South Carolina (South Carolina Department of Natural Resources, 2013) have heightened awareness of the importance of having up-to-date statistics for use in making critical water-resources decisions.

Because of the importance of these applications, it is critical to effectively measure and document stream base-flow data for use in updating low-flow statistics on a regular basis, preferably about every 10 years. Low-flow statistics, as defined in this report, are annual minimum daily mean streamflow averaged over designated periods (Riggs, 1972). The use of "average" with respect to the low-flow statistics in this report refers to the arithmetic mean. Low-flow statistics for streams in South Carolina have not been updated in a systematic way since 1987. In 2008, the U.S. Geological Survey (USGS), in cooperation with the SCDHEC, initiated a study to update low-flow statistics at continuous-record streamgaging stations (hereafter referred to as stations in this report) operated by the USGS in South Carolina. The investigation was originally planned for a period of 5 years to coincide with the SCDHEC Watershed Water Quality Management Strategy 
(WWQMS) for monitoring and assessment of eight major river basins in South Carolina (fig. 1), which is completed every 5 years (South Carolina Department of Health and Environmental Control, 2009; table 1). However, in 2010, the schedule for updating the low-flow statistics was modified at the request of the SCDHEC. The remaining basins were assessed by the USGS on a 2-year schedule with the results being published during the second year (table 1). This report documents the results from the last basin to be analyzed.

From the 1970s to the early 2000s, the USGS operated a network of streamgages on the Savannah River Site (SRS) (Cooney and others, 2003). The SRS, which is located in Aiken, Barnwell, and Allendale Counties, South Carolina, was created in 1951 to produce nuclear materials for national defense (Conrads and others, 2007). At the majority of the USGS streamgages in the SRS network, the streamflows were regulated by SRS operations. Consequently, low-flow statistics computed from those records may be of limited benefit for future water-resources planning because of uncertainty in the consistency of regulation patterns in the decade or so since streamflow monitoring ceased. Nonetheless, the SCDHEC requested that the USGS assess the records at seven of the SRS streamgages for suitability for low-flow computations (H. Rizzuti, South Carolina Department of Health and Environmental Control, written commun., 2014), which would provide a historical perspective of low-flow conditions at those streams.

\section{Purpose and Scope}

The purpose of this report is to present updated low-flow statistics at 28 continuous-record (CR) stations in the Savannah and Salkehatchie River Basins of South Carolina. The scope of the report includes both unregulated and regulated streams in the basins. Depending on the length of record available at the $\mathrm{CR}$ stations, the report presents estimates of annual minimum 1-, 3-, 7-, 14-, 30-, 60-, and 90-day average streamflows with recurrence intervals of 2, 5 , $10,20,30$, and 50 years (table 2, p. 33). In addition, daily flow durations for the 5-, 10-, 25-, 50-, 75-, 90-, and 95-percent probabilities of exceedance are presented for these stations.

\section{Previous Studies}

Previous reports by Stallings (1967), Johnson and others (1968), Bloxham and others (1970), Bloxham (1976, 1979, 1981), Barker (1986), Zalants (1991a, b), Feaster and Guimaraes $(2009,2012,2014)$, and Guimaraes and Feaster (2010) described the low-flow frequency and flow-duration streamflows for selected CR stations in South Carolina.

Stallings (1967) presented low-flow statistics for 61 CR stations and 83 other sites where flow was measured during the 1954 drought. Johnson and others (1968) focused on the low-flow statistics of streams in Pickens County. Low-flow streamflow measurements from 1945 through 1967 were presented for 32 partial-record (PR) stations. The PR stations were correlated with one of four potential index stations to estimate annual minimum 7-day average streamflow with 2- and 10-year recurrence intervals (7Q2 and 7Q10, respectively).

Bloxham and others (1970) presented magnitude and frequency of low-flow streamflows for nine CR stations in Spartanburg County, and streamflow measurements were presented for 63 sites. At 35 of the 63 sites, correlation methods were used with index stations to estimate the $7 \mathrm{Q} 2$ and 7Q10. Bloxham (1976) used six index stations from the upper Coastal Plain Physiographic Province to estimate the 7Q2 and $7 \mathrm{Q} 10$ at 54 PR stations and miscellaneous-measurement sites. Bloxham (1979) used data through the 1976 climatic year ${ }^{1}$ to compute low-flow frequency and flow-duration estimates at 71 CR stations in South Carolina.

Bloxham (1981) estimated the 7Q2 and 7Q10 at 113 PR stations in the Piedmont and lower Coastal Plain Provinces of South Carolina. Barker (1986) detailed the establishment of 361 PR stations with measurements made from August 1980 through July 1986. Zalants (1991a) provided estimates of the 7Q2 and 7Q10 at 564 PR stations and 27 CR stations on streams in the Blue Ridge, Piedmont, and upper Coastal Plain Provinces in South Carolina and parts of North Carolina and Georgia. Zalants (1991b) provided estimates of annual minimum 1-, 3-, 7-, 14-, 30-, 60-, and 90-day average streamflows with recurrence intervals of 2 to 50 years, depending on the length of record, for $55 \mathrm{CR}$ stations in South Carolina for which at least 5 years of unregulated daily mean streamflow data were available through the 1986 climatic year.

Feaster and Guimaraes $(2009,2012,2014)$ and Guimaraes and Feaster (2010) presented low-flow statistics for 17, 23, 25, and 11 CR stations in the Pee Dee River, Broad River, Saluda-Congaree-Edisto, and Catawba-Wateree and Santee River Basins in South Carolina, respectively. Low-flow estimates for the Pee Dee River, Broad River, SaludaCongaree-Edisto, and Catawba-Wateree and Santee River Basins were generated by using daily mean flow data through the 2006, 2007, 2008, and 2011 climatic years, respectively. In addition, daily flow durations of the 5- to 95-percent probabilities of exceedance were presented for most of these stations. Much of the general information for this report was taken directly from Feaster and Guimaraes $(2009,2012,2014)$ and Guimaraes and Feaster (2010).

\section{Description of the Study Area}

The study area for this report includes the Savannah and Salkehatchie River Basins of South Carolina. The Savannah River Basin forms the State boundary between Georgia and South Carolina with a small part of the basin being located in North Carolina (fig. 2). The Savannah River Basin has an area of 10,577 square miles $\left(\mathrm{mi}^{2}\right)$, which encompasses $4,581 \mathrm{mi}^{2}$

${ }^{1}$ The climatic (or climate) year is the 12-month period from April 1 through March 31 and is designated by the year in which the period begins. 


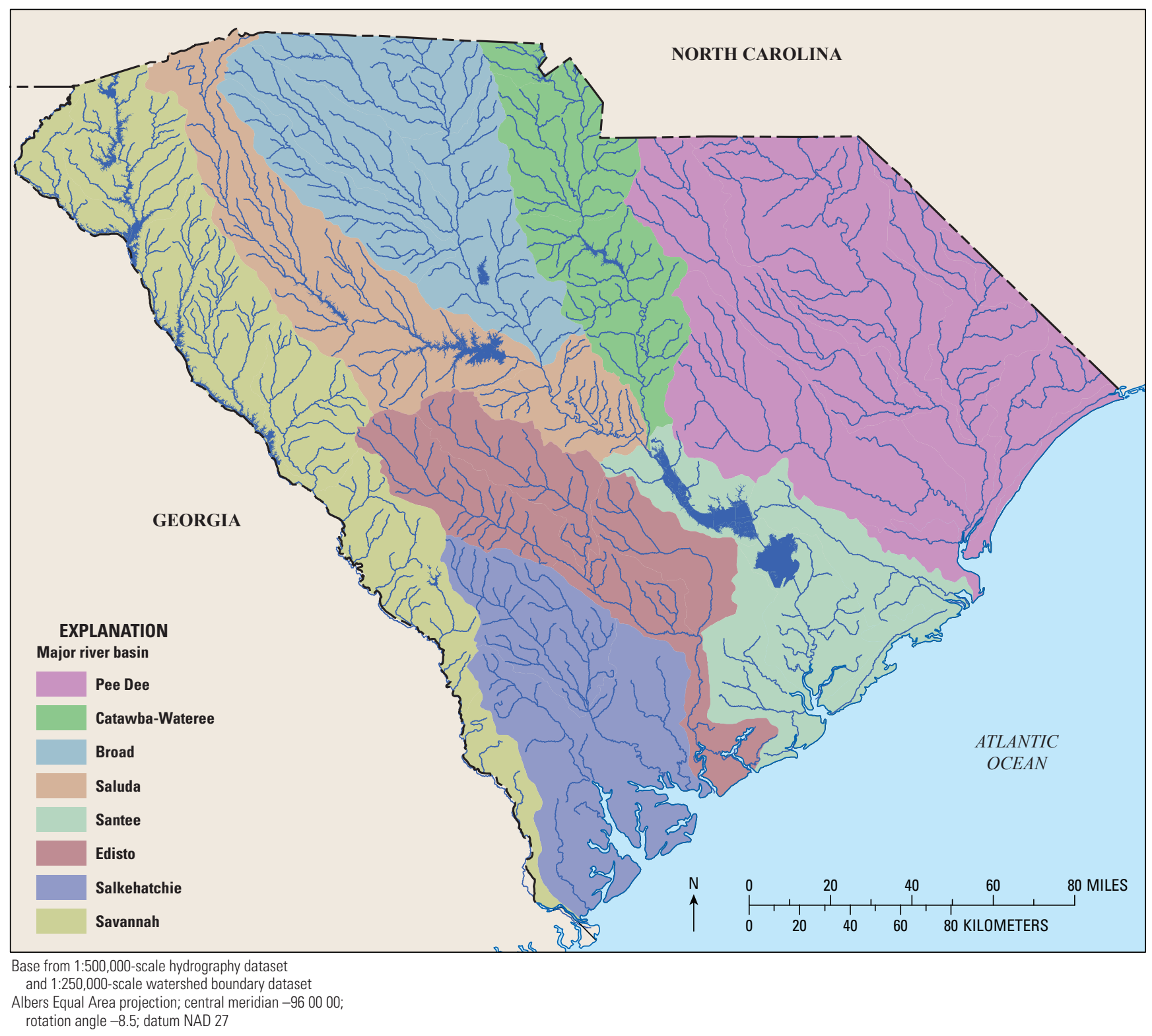

Figure 1. The eight major river basins in South Carolina as defined by the South Carolina Department of Health and Environmental Control. From Feaster and Guimaraes (2014).

Table 1. South Carolina Department of Health and Environmental Control (SCDHEC) schedule for basin data analysis and statistics availability.

[Modified from Feaster and Guimaraes (2014)]

\begin{tabular}{lcc}
\hline \multicolumn{1}{c}{ SCDHEC basin name (fig. 1) } & Data analysis, year ${ }^{1}$ & Low-flow information available, year $^{{ }^{1}}$ \\
\hline Pee Dee & 2008 & 2009 \\
Broad & 2009 & 2010 \\
Saluda and Edisto & 2010 and 2011 & 2012 \\
Catawba-Wateree and Santee & 2012 and 2013 & 2014 \\
Savannah and Salkehatchie & 2014 and 2015 & 2016 \\
\hline
\end{tabular}

\footnotetext{
${ }^{1}$ The year is the Federal fiscal year, which begins on October 1 and ends on September 30, and is designated by the calendar year in which the period ends.
} For example, fiscal year 2016 is the 12-month period from October 1, 2015, through September 30, 2016. 


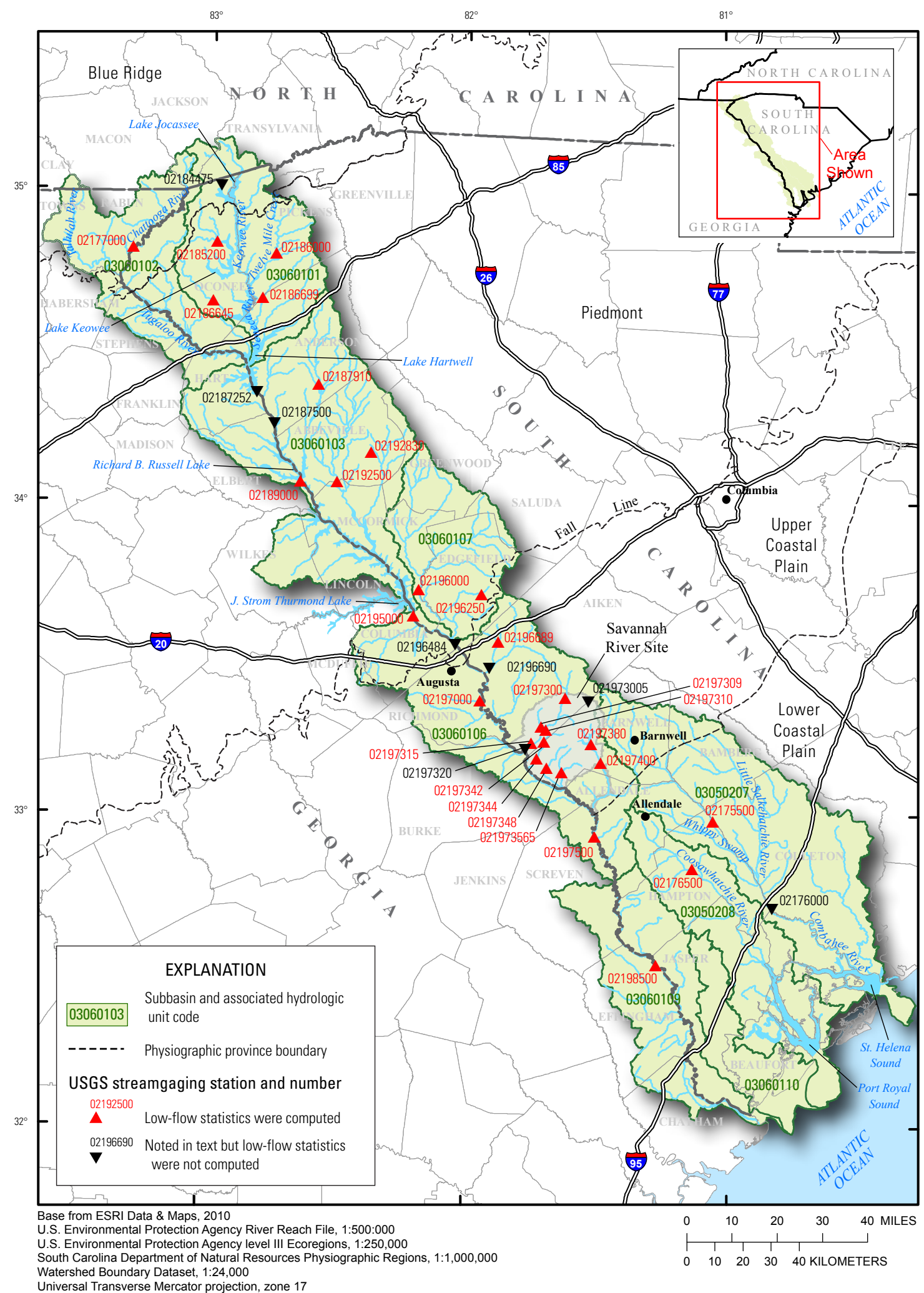

Figure 2. Eight-digit hydrologic unit code subbasins, subbasin name, and number of U.S. Geological Survey continuous-record streamgaging stations analyzed for the Savannah and Salkehatchie River Basins of South Carolina. 
in western South Carolina, 5,821 $\mathrm{mi}^{2}$ in eastern Georgia, and $175 \mathrm{mi}^{2}$ in southwestern North Carolina (Georgia Department of Natural Resources, 2001). In South Carolina, the Savannah River Basin is divided into six hydrologic unit subbasins designated by 8-digit Hydrologic Unit Codes (HUCs) (Eidson and others, 2005; table 3). The Salkehatchie River Basin in completely contained in South Carolina and is divided into three HUC subbasins encompassing 3,317 $\mathrm{mi}^{2}$.

The headwaters of the Savannah River Basin begin in the Blue Ridge Province of North Carolina, and the basin includes portions of the Blue Ridge Province in South Carolina and Georgia. The river flows through the Piedmont Province to the Coastal Plain Province where it empties into the Atlantic Ocean (fig. 2). The Savannah River is formed at the confluence of the Seneca River, which begins at the confluence of the Keowee River and Twelve Mile Creek, and the Tugaloo River, which begins at the confluence of the Tallulah and Chattooga Rivers. Both the Seneca and Tugaloo Rivers were inundated by construction of Lake Hartwell, which was completed in 1963 (South Carolina Department of Natural Resources, 2009). Lake Hartwell Dam is the first of three U.S. Army Corps of Engineer (USACE) projects conducted on the Savannah River and is located 89 miles above Augusta, Ga., and 7 miles below the confluence of the Tugaloo and Seneca Rivers (Georgia Department of Natural Resources, 2001). The city of Augusta, Ga., is on the Fall Line, which is the name given to the boundary between the Piedmont and Coastal Plain Provinces. Below Augusta, the lower Savannah River flows about 190 miles before discharging into the Atlantic Ocean. In the Coastal Plain Province, the Savannah River becomes much more sinuous and becomes a deltaic system branching into a series of interconnected distributary channels (Conrads and others, 2013).

Data pertaining to Lake Hartwell and other reservoirs in the Savannah River Basin are listed in table 4 (Feaster and others, 2009; South Carolina Department of Natural Resources, 2009).

The Salkehatchie River Basin is located in the Coastal Plain Province of South Carolina and encompasses approximately 2,860 $\mathrm{mi}^{2}$ (South Carolina Department of Health and Environmental Control, 2010). Defined by SCDHEC as one of the eight major river basins in South Carolina (fig. 1), the Salkehatchie River Basin also includes the Combahee and Coosawhatchie River subbasins. The Salkehatchie River originates near the City of Barnwell and includes drainage from Whippy Swamp before merging with the Little Salkehatchie River to form the Combahee River, which drains into St. Helena Sound. The Coosawhatchie River originates near the Town of Allendale and drains into Port Royal Sound.

Table 3. Eight-digit hydrologic unit code subbasins, subbasin name, and number of U.S. Geological Survey continuous-record streamgaging stations analyzed for the Savannah and Salkehatchie River Basins of South Carolina.

[HUC, hydrologic unit code; USGS, U.S. Geological Survey; Subbasins in bold text are wholly contained in South Carolina]

\begin{tabular}{|c|c|c|c|}
\hline $\begin{array}{c}\text { Eight-digit (subbasin) HUC } \\
\text { number (fig. 2) }\end{array}$ & Subbasin name & $\begin{array}{l}\text { Drainage area in South Carolina } \\
\text { (square miles) }\end{array}$ & $\begin{array}{l}\text { USGS continuous-record } \\
\text { streamgaging stations analyzed }\end{array}$ \\
\hline \multicolumn{4}{|c|}{ Salkehatchie River } \\
\hline 03050208 & Broad-St. Helena & 999 & 1 \\
\hline 03060110 & Calibogue Sound/Wright River & 430 & $\mathbf{0}$ \\
\hline 03060102 & Tugaloo & 340 & 1 \\
\hline 03060103 & Upper Savannah & 1,164 & 4 \\
\hline 03060106 & Middle Savannah & 1,020 & 14 \\
\hline 03060107 & Stevens & 740 & 2 \\
\hline
\end{tabular}


Low-Flow Frequency and Flow Duration of Selected South Carolina Streams in the Savannah and Salkehatchie River Basins

Table 4. Major reservoirs in the Savannah River Basin.

\begin{tabular}{lccc}
\hline \multicolumn{1}{c}{ Name of reservoir } & Date of completion & Drainage area (square miles) & $\begin{array}{c}\text { Flood-storage capacity } \\
\text { (acre-feet) }\end{array}$ \\
\hline${ }^{\text {a }}$ Lake Jocassee & 1975 & 147 & 136,000 \\
aa Lake Keowee & 1971 & 439 & 125,000 \\
Lake Hartwell & 1963 & 2,088 & 293,000 \\
Richard B. Russell Lake & 1985 & 2,900 & 140,000 \\
J. Strom Thurmond Lake & 1954 & 6,144 & 390,000 \\
\hline
\end{tabular}

${ }^{a}$ These reservoirs impound tributaries to the Savannah River.

\section{Low-Flow Statistics}

Low-flow statistics that define the magnitude and frequency of low-flow events typically are provided as a minimum average streamflow over some designated time period at a streamgaging location. For example, one of the most common low-flow statistics is the annual minimum 7-day average streamflow with a 10 -year recurrence interval (7Q10). In terms of probability of occurrence, there is a one-tenth or 10-percent probability that the annual minimum 7-day average streamflow in any single year will be equal to or less than the estimated 7Q10 value for a specific location (Riggs, 1985).

Daily mean streamflow data for this study were collected through March 31, 2014, which is the end of the 2013 climatic year, and are available through Web-based retrievals from the National Water Information System (NWIS) at http://waterdata.usgs.gov/sc/nwis/sw/. The climatic (or climate) year is a continuous 12-month period during which a complete annual cycle occurs and is arbitrarily selected for the presentation or analysis of data relative to hydrologic or meteorological phenomena (Langbein and Iseri, 1983). The climatic year typically is designated by the calendar year during which most of the 12 months occur. For this investigation, the climatic year is the 12-month period from April 1 through March 31 and is designated by the year in which the period begins. For example, the 2013 climatic year is the period from April 1, 2013, through March 31, 2014. In South Carolina, minimum streamflows typically occur in the autumn months of September, October, and November and, therefore, use of the climatic year, as defined, prevents the annual low-flow cycle from being artificially placed in separate years.

In order for the low-flow statistics to be updated for CR stations included in the previous study (Zalants, 1991b), at least three 3 years of additional streamflow data needed to be collected after 1987. Of the new CR stations for which data were collected after 1987, only the stations that had at least 5 years of data were included.

\section{Analytical Approach}

Four categories of CR stations were considered for analysis: (1) stations with 30 or more years of record, which the USGS designates as long-term streamgages (U.S. Geological Survey, 2013); (2) short-term record stations with between 10 and 30 years of record; (3) stations that have between 5 and 10 years of record, and which were analyzed for a limited set of low-flow statistics by using techniques typically used in analyzing PR stations; and (4) regulated stations.

Although low-flow statistics are computed at short-term record CR stations, computing low-flow statistics from stations with long-term records is preferred because the longterm records are typically more representative of a broad range of hydrologic conditions. Thus, long-term streamgaging data are better suited for trend assessments and statistical estimates.

The low-flow analyses detailed in this report are based on data collected only from CR stations. As with standard PR stations, however, similar techniques can be used to correlate daily mean flows at CR stations that have more than 5 years but less than 10 years of CR streamgaging data. In Feaster and Guimaraes (2009, 2012, 2014), and Guimaraes and Feaster (2010), such CR stations were referred to as PR-type stations and represented a third category of stations that were analyzed. Similar to the analyses at standard PR stations, only the 7Q2 and 7Q10 low-flow statistics were estimated at such CR stations. No PR-type stations, however, were analyzed in the Savannah and Salkehatchie River Basins because no suitable index stations were identified. Index station criteria will be discussed later in the report.

A fourth category of stations included in this study are $\mathrm{CR}$ stations on regulated streams. If an assessment of the daily mean flow at a regulated station indicates that the pattern of regulation has been relatively consistent, and if the logarithms of the $N$-day flows (where $N$ is the number of days used to compute the annual minimum average flow) are consistent with a Pearson Type III distribution, low-flow statistics can be computed for that period, using similar techniques as are used for the unregulated stations (Riggs, 1972). The techniques used for estimating low-flow statistics at PR sites generally are applicable only to unregulated streams and, therefore, should not be applied to streams that are highly regulated, such as for 
power generation. In addition, the low-flow statistics for regulated streams are relevant to similar future regulation patterns and would not be applicable if the future regulation patterns were altered substantially. Information regarding regulation at applicable CR stations is provided in the "Remarks" sections for stations listed in table 2. All stations considered for computations for low-flow statistics in the Savannah and Salkehatchie River Basins are listed in table 5 along with the period of record and drainage area for each station. A total of 36 stations were assessed, but three PR-type stations were removed because no suitable index station were identified and five regulated stations were removed because of insufficient record length or regulated conditions being such that a low-flow analysis was not warranted.

\section{Quality Assurance and Quality Control}

For this study, a quality assurance and quality control (QAQC) analysis was done on the annual minimum 7-day average streamflow data for the short- and long-term $\mathrm{CR}$ stations. The data at each station were reviewed for homogeneity, which implies relatively stable basin conditions during the period of record. The Kendall's tau test was used to assess the homogeneity of the record at each station (Helsel and Hirsch, 1992). The Kendall's tau test provides an independent measure of the monotonic relation between the " $\mathrm{X}$ " value (date) and the "Y" value (annual minimum 7-day average streamflow). A null hypothesis is made that the two variables are independent of each other and if the hypothesis is rejected, the independence of the variables is substantiated. A calculated probability value (p-value) estimates the probability of rejecting the null hypothesis. In this study, the independence of the two variables is considered statistically significant when the "p-value" is less than or equal to 0.05 . If a trend (nonhomogeneity) was indicated, additional assessments were used to determine if the trend may have been caused by a short-term condition. For example, if the station record happened to begin or end under extreme conditions (excessively wet or dry), the test may indicate a trend, but additional analysis that excludes the extreme events may indicate no trend. Trends at unregulated stations may result from changes in climatic cycles, land use, groundwater pumping, or other practices that may affect groundwater levels. For stations downstream from a major source of regulation, such as a dam, the data were assessed for gross trends, which may indicate a long-term change in the pattern of regulation (William Kirby, U.S. Geological Survey, written commun., June 6, 2005). Additionally, some investigations have shown that substantial urbanization can lead to a reduction in low flows (U.S. Environmental Protection Agency, 2009). Final decisions to include or exclude data from a specific station analysis were made by using hydrologic judgment based on the results of the QAQC analyses and other available information, such as comparisons with other long-term stations.

The QAQC analyses included the use of several computer programs that were developed by using commercial statistical software (SAS Institute, Inc., 1989). The components of the QAQC reviews that were conducted for the CR stations are as follows:

- Plot of the ratios of median daily mean flows during the weekend (Saturday and Sunday) and entire week (Sunday through Saturday), and work week (Monday through Friday) and entire week against climatic year. These plots are useful for regulated streams and can show if the discharge patterns differ from week days to weekends.

- The Kendall's tau test to check for trends in the annual minimum 7-day average streamflow data over time.

- Plot of the annual minimum 7-day average streamflow against climatic year, which is used along with the Kendall's tau results to assess potential trends.

- Plot of the relation of the ratio of the 10th percentile to the 50th percentile of the average 7-day flows (loratio) against climatic year, which is useful for graphically assessing potential trends.

- Plot of the relation of the 50th percentile of the average 7-day flow against climatic year. This plot is useful for assessing potential changes in the median average 7-day flow over time.

- Plot of the cumulative annual minimum 7-day average streamflow against climatic year. This type of plot is known as a single-mass curve. A substantial change in the slope of this relation indicates a change in flow patterns.

- Plot of the relation of the cumulative loratio against climatic year. A substantial change in the slope of this relation indicates a change in flow patterns.

- Plot of the relation of the cumulative 50th percentile of the average 7-day flow against climatic year. A substantial change in the slope of this relation indicates changes in the median average 7-day flow patterns.

A trend analysis, as described previously, was made for all stations in the investigation by using a p-value of 0.05 , which is the probability of obtaining the computed test statistic, or one even less likely, when the null hypothesis is true (Kendall, 1938; Helsel and Hirsch, 1992). For the Kendall's Tau trend analysis used in this study, the null hypothesis is that there is no trend in the annual minimum 7-day average flow data. The Kendall's Tau test is based on the assessment of concordant (when both the $\mathrm{x}$ and $\mathrm{y}$ variables increase or decrease) and discordant (when $\mathrm{x}$ increases and $\mathrm{y}$ decreases or $\mathrm{x}$ decreases and $\mathrm{y}$ increases) pairs of $x$ and $y$ data (Kendall, 1938). Consequently, when stations have a substantial number of zero flows, such as station 02176500, Coosawhatchie River near Hampton, SC, interpretation of the Kendall's Tau trend test can become tenuous at best because of ties in the data. 


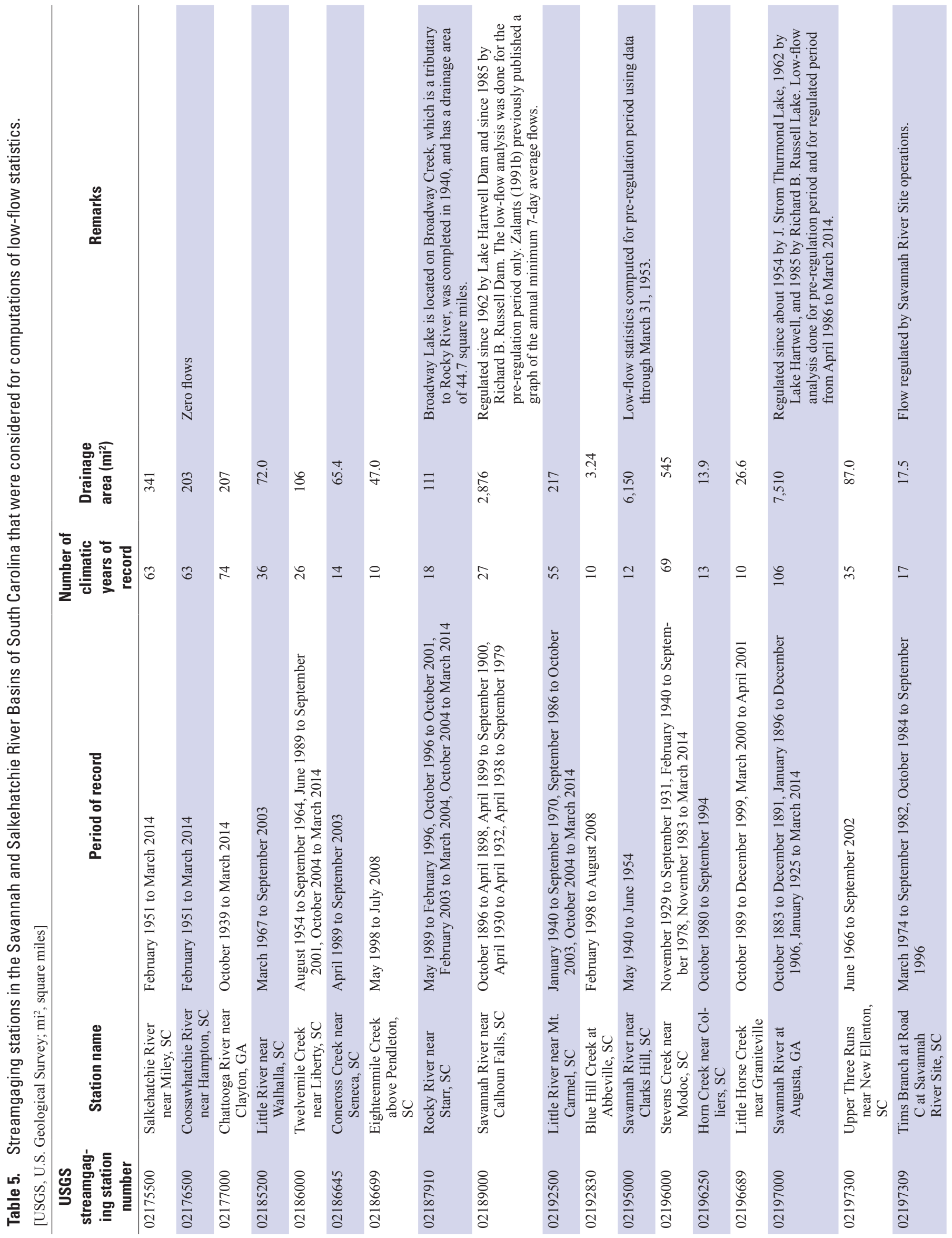




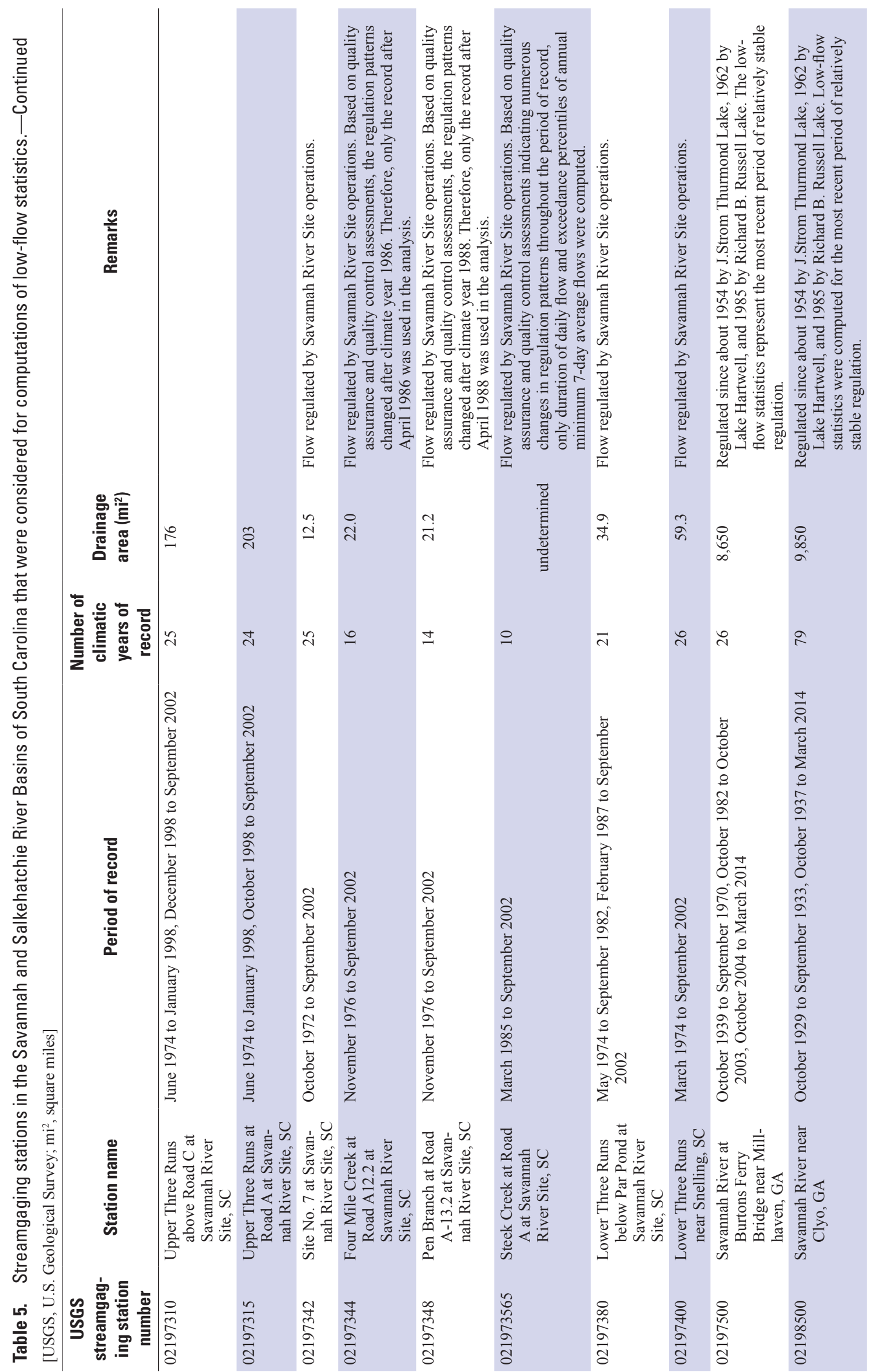




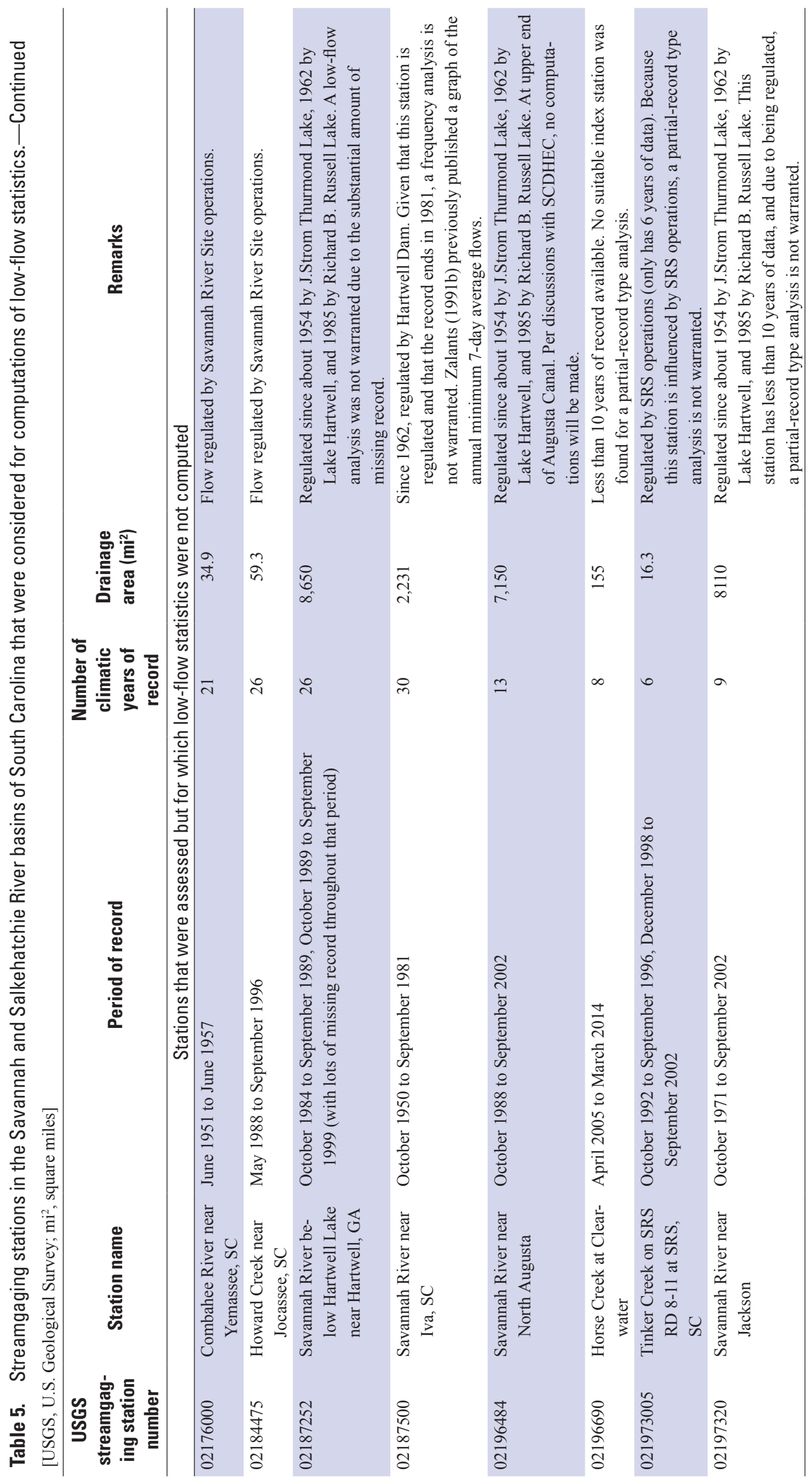




\section{Results of Quality Assurance and Quality Control Analyses}

For the following unregulated stations, the analyses indicated a trend in the annual minimum 7-day average streamflow for the period of record analyzed: 02175500 , Salkehatchie River near Miley, SC; 02176500, Coosawhatchie River near Hampton, SC; 02185200, Little River near Walhalla, SC; 02186000, Twelvemile Creek near Liberty, SC; 02186645, Coneross Creek near Seneca, SC; 02187910 , Rocky River near Starr, SC; and 02192500, Little River near Mt. Carmel, SC. As can be seen in figure 3, the annual minimum 7-day average flows for the unregulated streamgages have been historically low in recent years likely because of lower precipitation that has occurred in the Southeast during the last several decades. Consequently, it is likely that these trends are a reflection of the streamgage records ending during these historically drier periods. If these periods are actually part of a short-term hydrologic regime and not reflective of a shift in long-term climatic conditions, when viewed in terms of longer timeframes, the periods may just be part of a much longer term oscillation (Feaster and Guimaraes, 2009, 2012; Guimaraes and Feaster, 2010; Lins and others, 2010). As can be seen in the plot of the statewide total annual precipitation in South Carolina from 1895 to 2014, a trend line fit through all of the precipitation data tracks closely with the mean for that period, indicating no trend over the longer period of record (fig. 4A; National Oceanic and Atmospheric Administration, 2016). A historic drought in the 1950 s transitioned into a relatively wet period in the 1960 s and 70 s. Since that wet period, however, the total annual precipitation has tended to trend downward (fig. 4B). Fitting a linear trend line through the data from 1960 to 2014 shows a downward trend in the total annual precipitation, which is similarly reflected in the streamflow data (fig. 3). For comparison purposes, plots of the annual minimum 7-day average flows for the unregulated stations analyzed in this report for which no trends were indicated are shown in figure 5.

Interpretations of trend analyses are more complicated for the regulated streamgages. Streamflows at regulated stations also are influenced by changes in climatic patterns, but those changes can be mitigated, enhanced, or even offset by changes in regulation patterns. Nonetheless, assessments in the flow patterns are useful to help determine the appropriateness of a frequency analysis at a regulated streamgage. Thus, the trend test also was done for the regulated streamgages. For the following regulated streamgages, no trend was indicated in the annual minimum 7-day average flows: 02197309, Tims Branch at Road C at Savannah River Site, SC; 02197380, Lower Three Runs below Par Pond at Savannah River Site, SC; 02197400, Lower Three Runs near Snelling, SC; 02197500, Savannah River at Burtons Ferry Bridge near Millhaven, GA (regulated period from climatic year [CY] 1986 to 2013); and 02198500, Savannah River near Clyo, GA (regulated period from CY 1986 to 2013) (fig. 6A). Trends were indicated for 02197000, Savannah River at Augusta, GA (regulated period from CY 1986 to 2013); 02197342, Site No. 7 at Savannah River Site, SC; 02197344, Four Mile Creek at Road A12.2 at Savannah River Site, SC; and 02197348, Pen Branch at Road A-13.2 at Savannah River Site, SC (fig. 6B). 


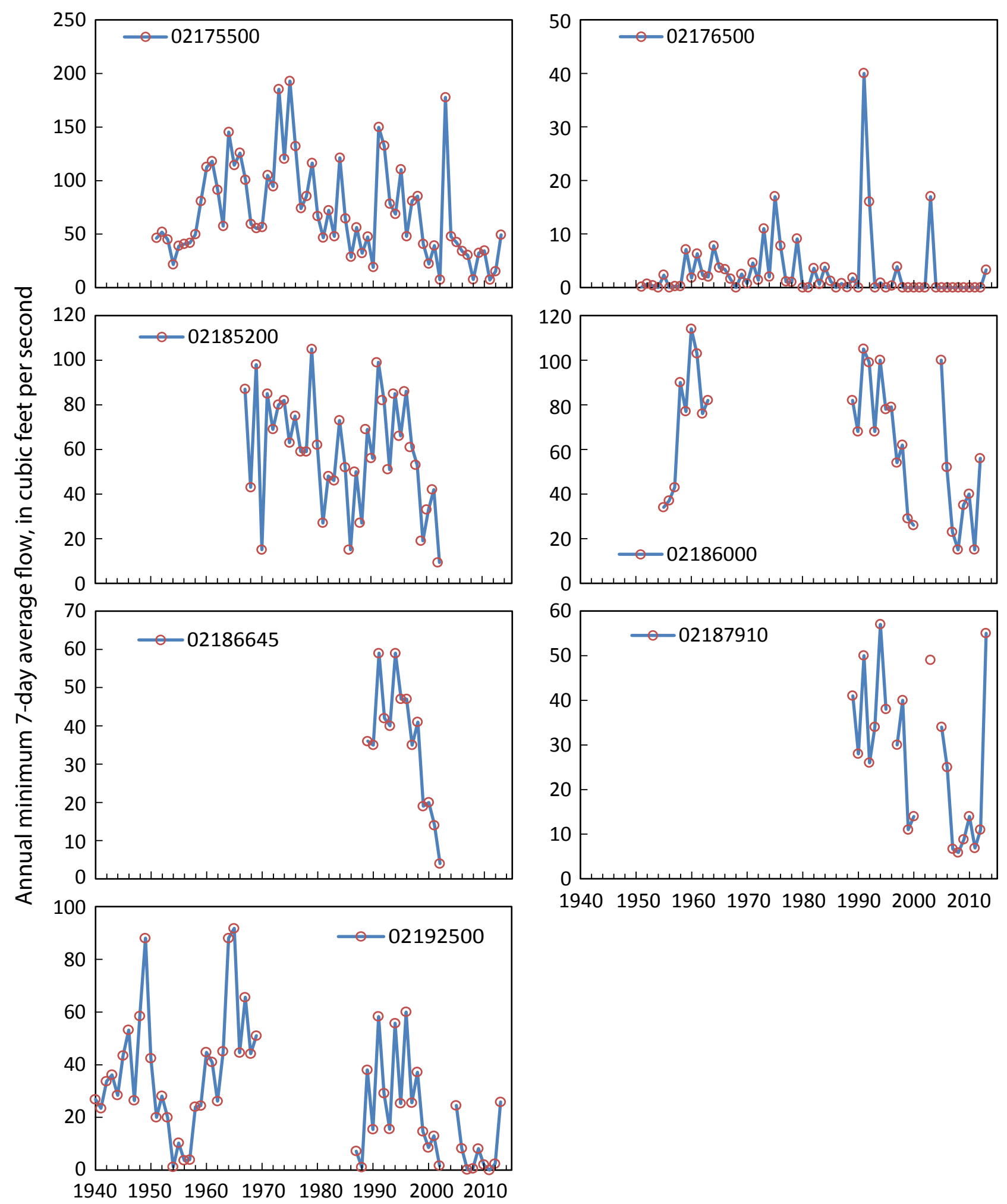

Climatic Year

Figure 3. Annual minimum 7-day average streamflow at unregulated U.S. Geological Survey streamgaging stations included in this investigation that indicated a trend for the period analyzed: 02175500, Salkehatchie River near Miley, SC; 02176500, Coosawhatchie River near Hampton, SC; 02185200, Little River near Walhalla, SC; 02186000, Twelvemile Creek near Liberty, SC; 02186645, Coneross Creek near Seneca, SC; 02187910, Rocky River near Starr, SC; and 02192500, Little River near Mt. Carmel, SC. 


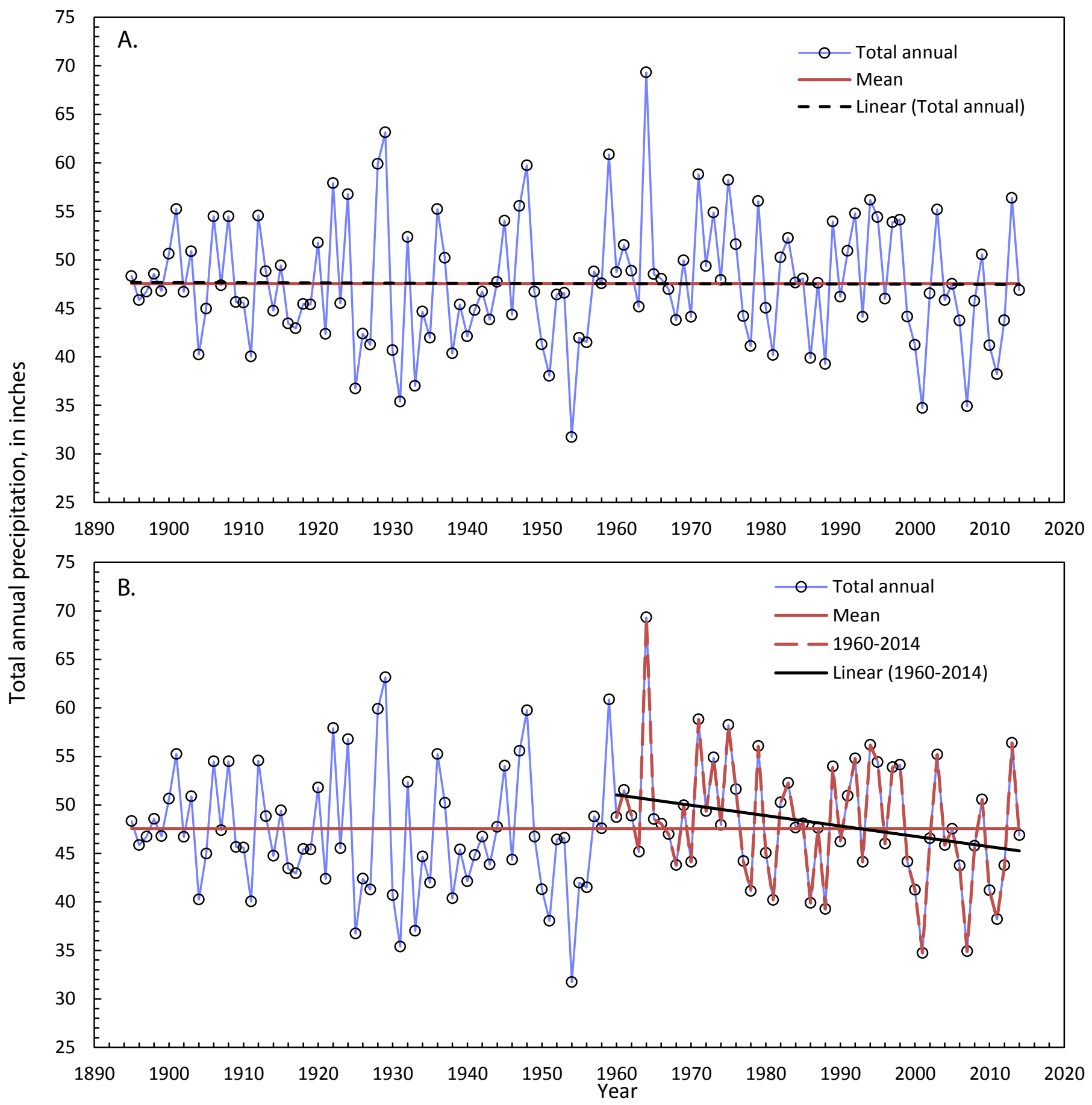

Figure 4. Total annual statewide precipitation for South Carolina (A) indicating no trend in the period from 1895 to 2014 and, (B) indicating a downward trend in the period from 1960 to 2014. 

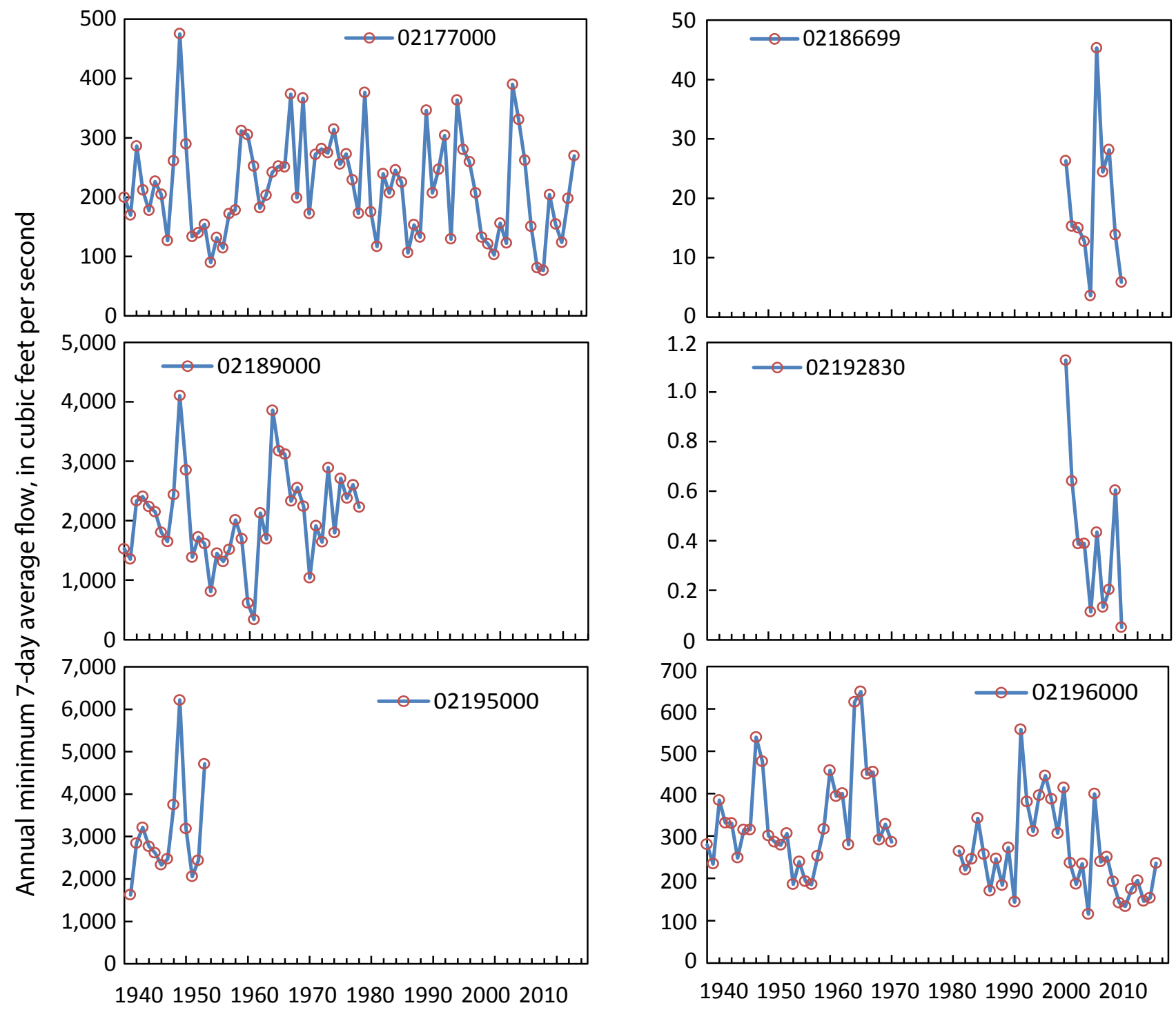

Climatic year

Figure 5. Annual minimum 7-day average streamflow at unregulated U.S. Geological Survey streamgaging stations included in this investigation that indicated no trend for the period analyzed: 02177000, Chattooga River near Clayton, GA; 02186699, Eighteenmile Creek above Pendleton, SC; 02189000, Savannah River near Calhoun Falls, SC; 02192830, Blue Hill Creek at Abbeville, SC; 02195000, Savannah River near Clarks Hill, SC; 02196000, Stevens Creek near Modoc, SC; 02196250, Horn Creek near Colliers, SC; 02196689, Little Horse Creek near Graniteville; 02197300, Upper Three Runs near New Ellenton, SC; 02197310, Upper Three Runs above Road C at Savannah River Site, SC; and 02197315, Upper Three Runs at Road A at Savannah River Site, SC. 

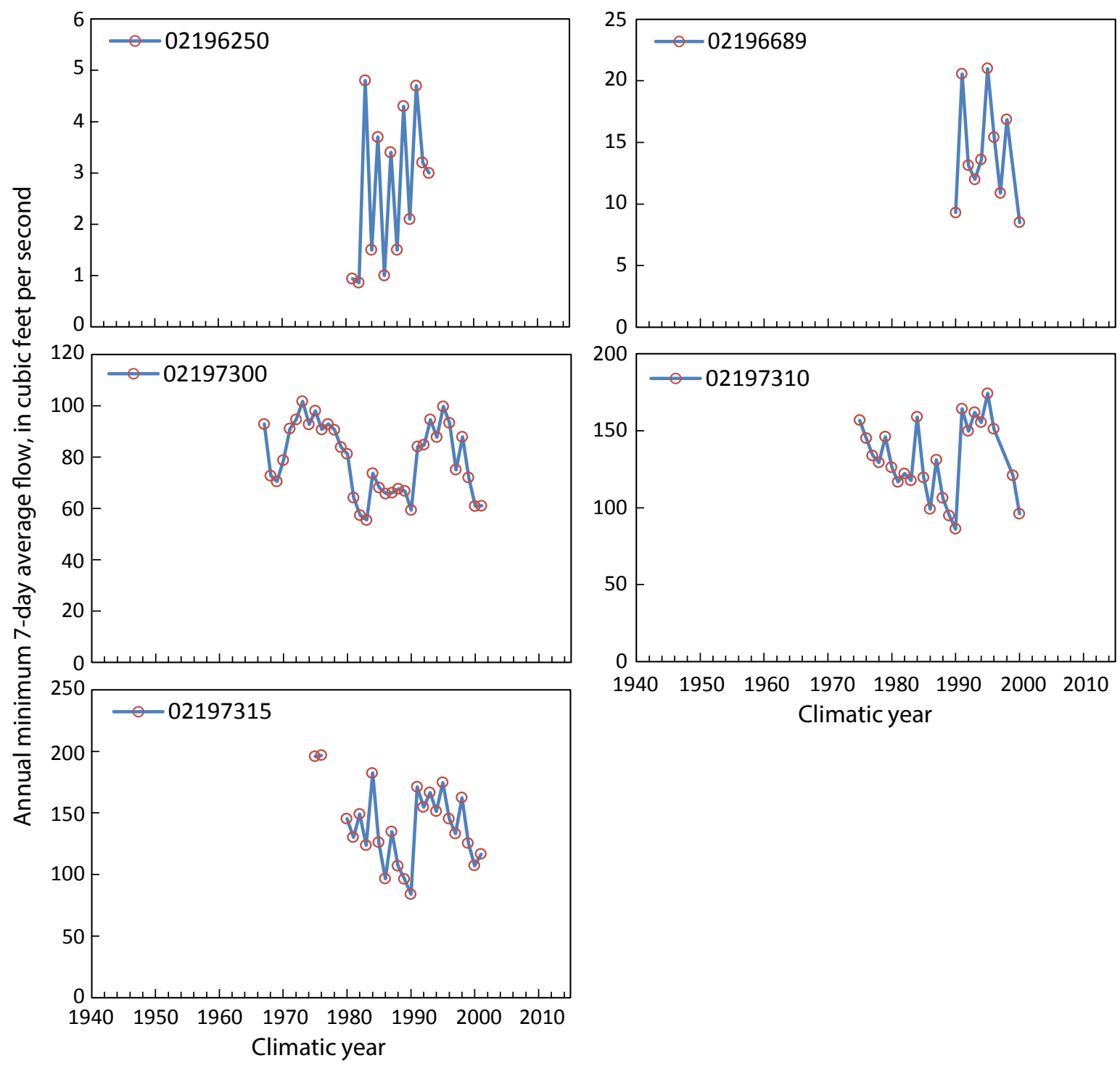

Figure 5. Annual minimum 7-day average streamflow at unregulated U.S. Geological Survey streamgaging stations included in this investigation that indicated no trend for the period analyzed: 02177000, Chattooga River near Clayton, GA; 02186699, Eighteenmile Creek above Pendleton, SC; 02189000, Savannah River near Calhoun Falls, SC; 02192830, Blue Hill Creek at Abbeville, SC; 02195000, Savannah River near Clarks Hill, SC; 02196000, Stevens Creek near Modoc, SC; 02196250, Horn Creek near Colliers, SC; 02196689, Little Horse Creek near Graniteville; 02197300, Upper Three Runs near New Ellenton, SC; 02197310, Upper Three Runs above Road C at Savannah River Site, SC; and 02197315, Upper Three Runs at Road A at Savannah River Site, SC.-Continued 
A.

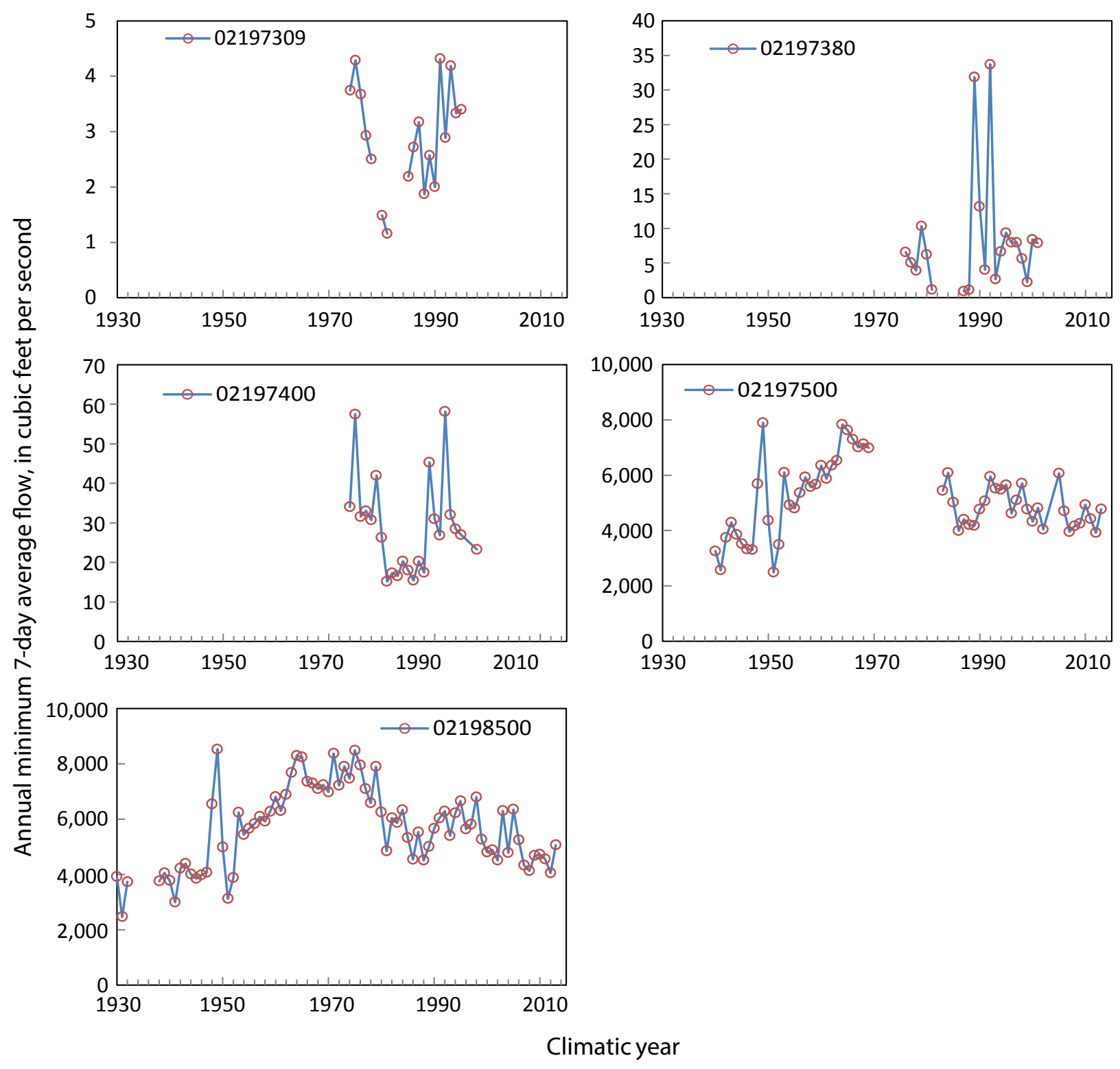

Figure 6. Annual minimum 7-day average streamflow at regulated U.S. Geological Survey streamgaging stations included in this investigation that indicated (A) no trends in the data: 02197309, Tims Branch at Road C at Savannah River Site, SC; 02197380, Lower Three Runs below Par Pond at Savannah River Site, SC; 02197400, Lower Three Runs near Snelling, SC; 02197500, Savannah River at Burtons Ferry Bridge near Millhaven, GA; and 02198500, Savannah River near Clyo, GA; and (B) trends in the data: 02197000, Savannah River at Augusta, GA; 02197342, Site No. 7 at Savannah River Site, SC; 02197344, Four Mile Creek at Road A12.2 at Savannah River Site, SC; and 02197348, Pen Branch at Road A-13.2 at Savannah River Site, SC. 
B.
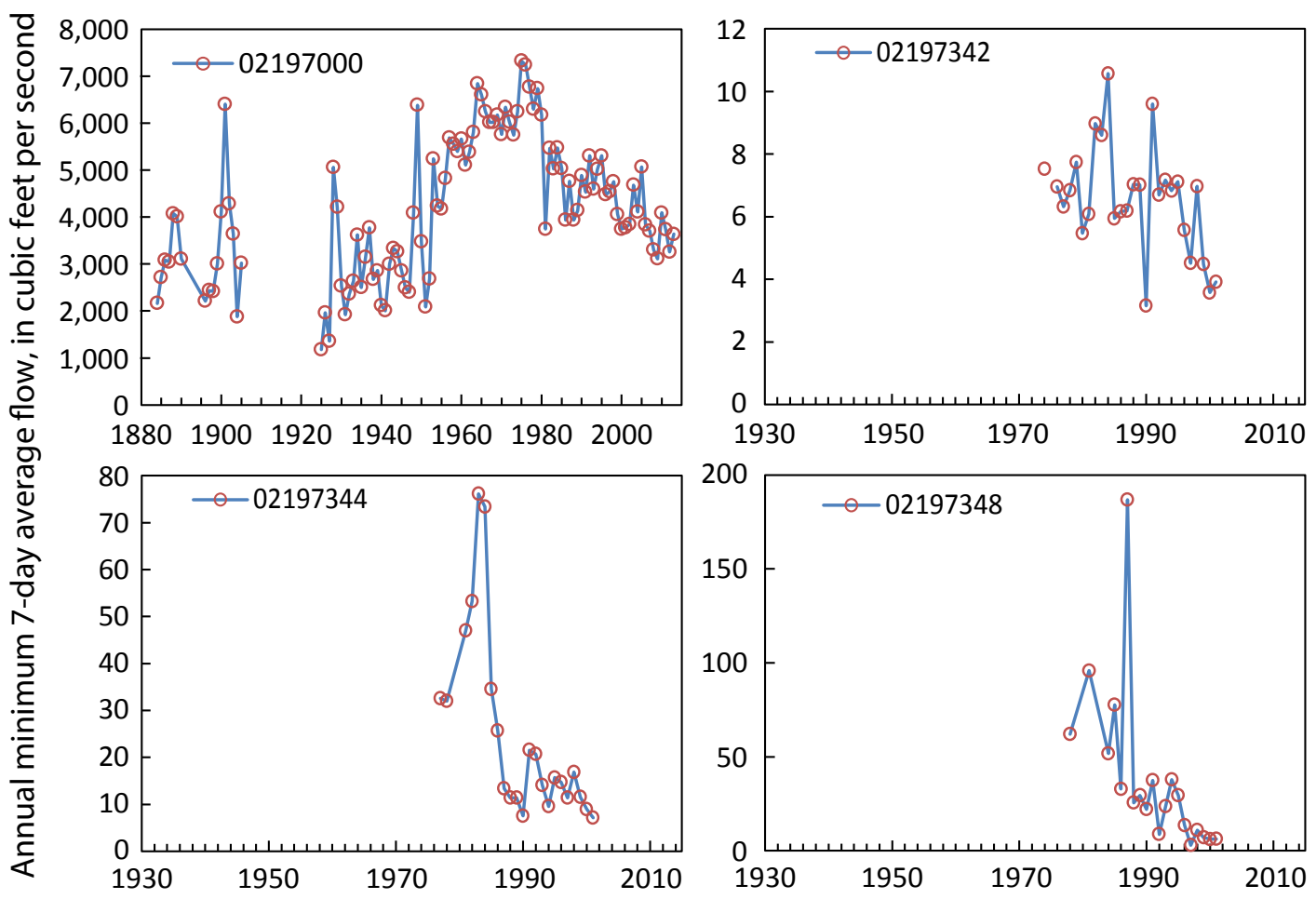

Climatic year

Figure 6. Annual minimum 7-day average streamflow at regulated U.S. Geological Survey streamgaging stations included in this investigation that indicated (A) no trends in the data: 02197309, Tims Branch at Road C at Savannah River Site, SC; 02197380, Lower Three Runs below Par Pond at Savannah River Site, SC; 02197400, Lower Three Runs near Snelling, SC; 02197500, Savannah River at Burtons Ferry Bridge near Millhaven, GA; and 02198500, Savannah River near Clyo, GA; and (B) trends in the data: 02197000, Savannah River at Augusta, GA; 02197342, Site No. 7 at Savannah River Site, SC; 02197344, Four Mile Creek at Road A12.2 at Savannah River Site, SC; and 02197348, Pen Branch at Road A-13.2 at Savannah River Site, SC.-Continued 


\section{Diversions}

Diversions from natural streamflows occur for a variety of reasons. Some diversions are the result of water-supply withdrawals, manufacturing, point-source discharges, and agricultural needs, such as irrigation. Diversions by manufacturers are sometimes confined to short distances along rivers. Water may be taken from the river channel, passed through the manufacturing plant for use in processing, cooling, or dilution of wastes, and then returned to the river. Therefore, in many cases, consumptive losses from diversions by manufacturers may be negligible (Ries, 1994). Thus, the effects of diversions to the streamflow regime of a river are variable and depend not only on where the diversions occur but also on the final outcome of the diverted water.

Ries (1994) noted that water diverted from a stream or adjacent aquifer for municipal supplies is returned to the basin as effluent from individual septic systems or from wastewatertreatment plants within the basin and generally causes little loss of water to the basin; however, such diversions may affect the temporal pattern of streamflows. Diversions from one basin to another reduce streamflow in the donor basin and increase streamflow in the receiving basin. Diversions between subbasins of a larger basin can substantially affect streamflows in the subbasins, but if consumptive losses are negligible, streamflows in the larger basin may be nearly unaffected. The various diversion scenarios described above indicate that a proper accounting of all diversions in a basin may be difficult; therefore, most USGS low-flow analyses are made on the flow data as measured at the station without adjustments for diversions.

\section{Frequency Analysis}

Low-flow frequency statistics at CR stations are computed by fitting a series of annual minimum $N$-day average streamflows to some known statistical distribution, where $N$ can equal any number from 1 to 365 . Low-flow frequency statistics for this study were computed by fitting logarithms (base 10) of the annual minimum 1-, 3-, 7-, 14-, 30-, 60-, and 90-day average streamflows to a Pearson Type III distribution, which also is referred to as a log-Pearson Type III distribution. Fitting the distribution requires calculating the mean, standard deviation, and skew coefficient of the logarithms of the $N$-day streamflows. Estimates of the $N$-day non-exceedance flows for a specified recurrence interval $T$ are computed by using the following equation:

$$
\log Q_{T}=\bar{X}+K S
$$

where

$$
\begin{gathered}
Q_{T} \quad \begin{array}{l}
\text { is the } N \text {-day low flow, in cubic feet per } \\
\text { second, and } T \text { is the recurrence interval, in } \\
\text { years; }
\end{array} \\
\bar{X} \quad \begin{array}{l}
\text { is the mean of the logarithms of the annual } \\
\text { minimum } N \text {-day average streamflows; }
\end{array}
\end{gathered}
$$

$K \quad$ is a frequency factor that is a function of the recurrence interval and the coefficient of skew; and

$S \quad$ is the standard deviation of the logarithms of the annual minimum $N$-day average streamflows.

Low-flow statistics typically are presented as a set of non-exceedance probabilities or, alternatively, recurrence intervals along with the associated low-flow values. The non-exceedance probability is defined as the probability that a flow at a given station will be equal to or less than the associated low-flow value once in a 1-year period and is expressed as a decimal fraction less than 1.0 or as a percentage less than 100. Recurrence interval is defined as the average interval of years (often referred to as the return period) during which flows at a given station will be equal to or less than the associated low-flow value once. For example, a low-flow value at a given station with a non-exceedance probability of 0.10 indicates that flows at that station have a 10-percent chance of being equal to or less than the low-flow value once in any given year. Recurrence interval and non-exceedance probability are the mathematical inverses of one another; therefore, a flow with a non-exceedance probability of 0.10 has a recurrence interval of 1 divided by 0.10 or 10 years. Recurrence intervals, regardless of length, always refer to an average period of time (or years) in which flows at a given station will be equal to or less than the associated low-flow value once. A 10-year recurrence interval does not imply that the low-flow value will have a non-exceedance every 10 years; it does indicate, however, that the average time between recurrences is equal to 10 years. Consequently, an observed interval between a non-exceedance of the 7Q10 may be as short as 1 year or may be considerably longer than 10 years.

The low-flow frequency curve is generated by application of equation 1 to a set of annual minimum $N$-day average flows for a range of specified return periods. To estimate low-flow statistics for recurrence intervals greater than the period of record, these frequency curves must be extended. For this study, the following criteria were used to limit the extension of the curves based on the period of record at the station, and the following criteria were established for extending frequency curves:

1. Curves for stations with 10 or more years of annual lowflow streamflow record but less than 20 years of record were extended to a recurrence interval of 20 years;

2. Curves for stations with 20 or more years of record but less than 30 years of record were extended to a recurrence interval of 30 years; and

3. Curves for stations with 30 or more years of record were extended to a recurrence interval of 50 years. No data were compiled for recurrence intervals greater than 50 years.

An example of the frequency curve using the log-Pearson Type III curve-fitting procedure is illustrated in figure 7. 
Station 02177000, Chattooga River near Clayton, GA

7-day low flow, in cubic feet per second

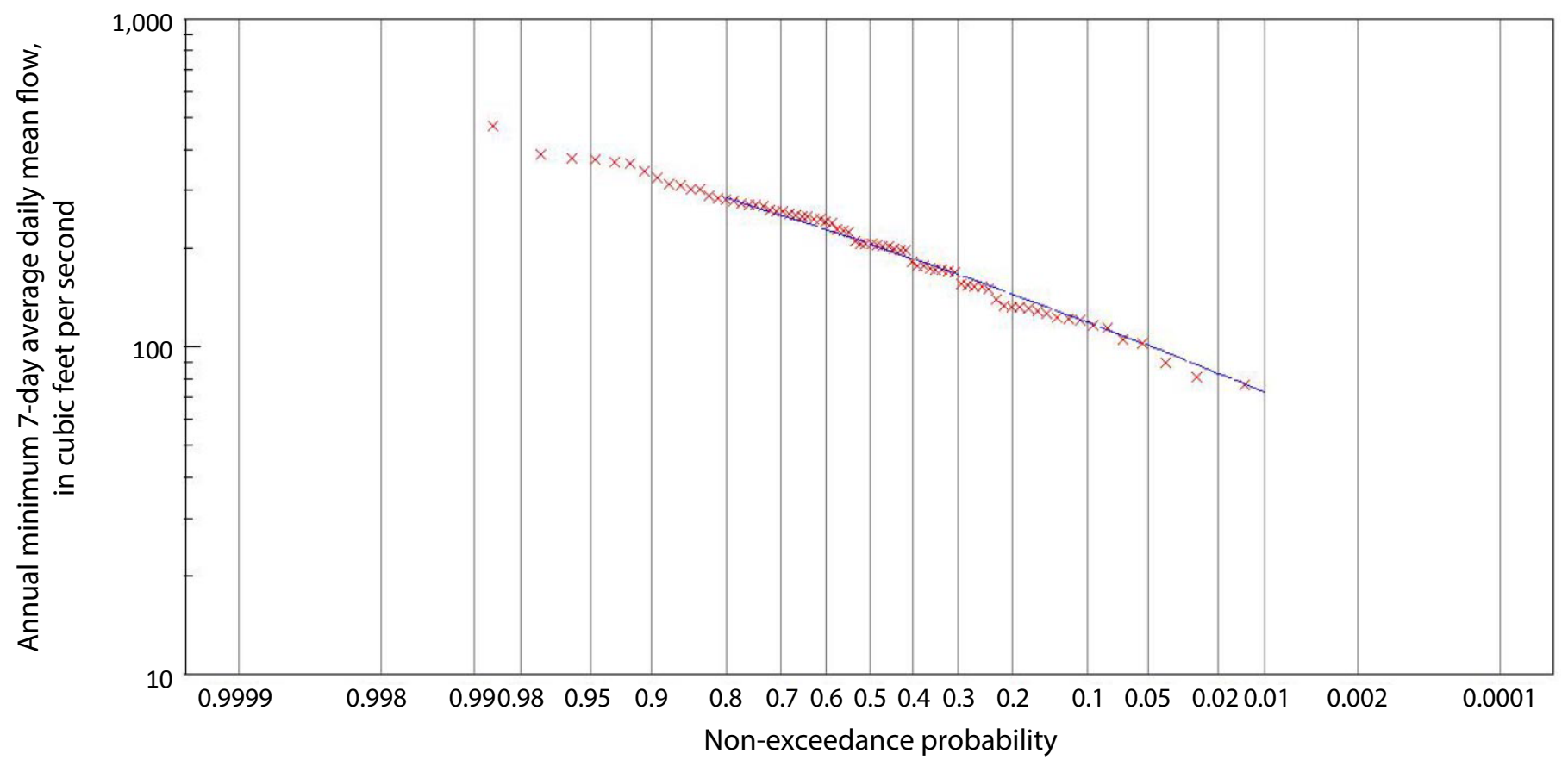

Figure 7. Low-flow frequency curve for the annual minimum 7-day average streamflow for the U.S. Geological Survey streamgaging station 02177000, Chattooga River near Clayton, GA.

\section{Record-Extension Technique}

Streamflow statistics often are needed to estimate probabilities of occurrences for periods much longer than the actual measured period of record. Consequently, short records that may have been collected during an unusually dry, wet, or otherwise unrepresentative period may not represent the more desirable fuller range of potential hydrologic regimes. Under certain conditions, it is possible to extend or augment a short record by using a correlated station having a longer record. The extended record at the short-term record station will better reflect low-flow conditions over a longer period and provide better estimates of low-flow statistics at that station. The record extension can be accomplished in the following manner.

If a linear relation between the logarithms of the $N$-day flows at a short-term record station is determined to be significantly correlated to a concurrent set of the $N$-day flows at a long-term record station, or index station, a mathematical record-extension method known as the Maintenance of Variance Extension, Type 1 (MOVE.1) method (Hirsch, 1982) can be used to extend the record at the short-term record station. The MOVE.1 relation maintains the mean and the variance of the data at the short-term record station and, therefore, allows for the generation of a longer-term set of data that will possess the statistical characteristics of the actual measured data from the short-term record.
The MOVE.1 equation is

$$
Y_{i}=\bar{Y}+\frac{S_{y}}{S_{x}}\left(X_{i}-\bar{X}\right)
$$

where

$Y_{i} \quad$ is the logarithm of the estimated $N$-day flow for the short-term record station;

$\bar{Y} \quad$ is the mean of the logarithms of $N$-day flows for the concurrent period at the short-term record station;

$S_{y} \quad$ is the standard deviation of the logarithms of $N$-day flows for the concurrent period at the short-term record station;

$S_{x} \quad$ is the standard deviation of the logarithms of $N$-day flows for the concurrent period at the long-term record station or index station;

$X_{i} \quad$ is the logarithm of the flow statistic or observed $N$-day flow at the index station; and

$\bar{X} \quad$ is the mean of the logarithms of the $N$-day flows for the concurrent period at the index station. 
In order for an index station to be considered for this study, it had to have (1) a minimum of 10 years of concurrent record relative to the short-term record station, (2) similar basin geology as the short-term record station, and (3) a basin less than 10 times larger than the size of the smaller basin (Telis, 1991). A minimum correlation coefficient between concurrent flows has not been developed for the MOVE.1 technique; however, similar correlation studies have used values ranging from 0.70 to 0.80 (Hydrology Subcommittee of the Interagency Advisory Committee on Water Data, 1982; Stedinger and Thomas, 1985; Ries, 1994; Nielsen, 1999). In addition, if the record at the short-term record station or available index station included zero flows, record extensions were not applied because including such values in record-extension techniques has not be adequately tested (Julie Kiang, U.S. Geological Survey Office of Surface Water, written commun., January 26, 2010). Several of the short-term stations were tested for the possibility of record augmentation but on the basis of these criterion, it was determined that no record augmentations were warranted for the Savannah and Salkehatchie River Basin stations.

For gaging stations that have relatively long records, such as 30 years or more, record extension may still be beneficial if an index station is available that has additional record collected under hydrologic conditions that are not included in the record being analyzed. Currently, there are no standard criteria for assessing when the use of MOVE. 1 is warranted with respect to improvement in the low-flow statistics at such stations. Therefore, for this investigation, an arbitrary criterion was set. The 7-day low-flow statistics at the index station were computed using the complete period of record and the period of record that was concurrent with the station of interest. If the average difference in the 7-day low-flow statistics for the two periods at the index station was greater than 10 percent, MOVE. 1 was used to augment the record at the station of interest. Otherwise, no augmentation was done. On the basis of this criterion, no station records were augmented for the Savannah and Salkehatchie River Basins.

\section{Partial-Record Type Analysis}

As previously discussed, when limited streamflow data are collected on a systematic basis over a period of years for use in hydrologic analyses, the data-collection site is called a partial-record (PR) station (Zalants, 1991a). With respect to low-flow statistics, once a sufficient number of base-flow measurements have been made over a reasonable period of time, techniques can be used to transfer low-flow statistics from an index station to the PR station (Riggs, 1972). If the relation between the flows at the PR station and the index station is linear, mathematical correlation methods, such as MOVE.1, can be used (Hirsch, 1982). If the relation is nonlinear, then a graphical correlation described by Riggs (1972) can be used.

The MOVE. 1 technique can be used to establish a relation between the concurrent daily mean flows. In order to use daily mean flows that are representative of low-flow conditions, only concurrent flows that are less than or equal to the 90-percent flow duration at the index station were used in the MOVE. 1 analysis. That relation is then used to transfer a limited set of low-flow statistics from an appropriate index station to the PR station. Similar criteria as were described for extending the record at a short-term record station can be used with the exception of the concurrent-record length. U. S. Geological Survey Office of Surface Water Technical Memorandum No. 86.02 (U.S. Geological Survey, 1985) recommended that only the 7Q2 and 7Q10 statistics be estimated for the PR stations. Because of the limited records available at the PR stations, providing a broader set of statistics would imply an accuracy that is not warranted.

The same MOVE.1 equation (eq. 2) as described previously is used to transfer the low-flow characteristic from the index station to the PR station. The difference is that now $X_{i}$ is the low-flow characteristic computed from the index or long-term record station, and $Y_{i}$ is the low-flow characteristic estimated at the PR station. Three CR stations in the Savannah and Salkehatchie River Basins had at least 5 years but less than 10 years of record (table 4): 02176000, Combahee River near Yemassee, SC; 02184475, Howard Creek near Jocassee, SC; and 02196690, Horse Creek at Clearwater, SC. No suitable index station was found for these three stations and therefore, no record augmentation was done.

\section{Flow-Duration Analysis}

Flow durations represent the percentage of time that a specified streamflow is equaled or exceeded during a given period (Searcy, 1959). Flow durations are computed by sorting the daily mean flows for the period of record from the largest value to the smallest value and assigning each streamflow value a rank, starting from 1 to the largest value. The frequencies of exceedance are then computed using the Weibull formula for computing plotting position (Helsel and Hirsch, 1992):

$$
P=100 *[M /(n+1)]
$$

where

$$
\begin{gathered}
P \quad \text { is the probability that a given flow will be } \\
\text { equaled or exceeded (percentage of time), } \\
M \quad \begin{array}{c}
\text { is the ranked position (dimensionless), and } \\
n \quad \text { is the number of events for the period of }
\end{array} \\
\text { record (dimensionless). }
\end{gathered}
$$

Flow durations are a summary of the past hydrologic events. Yet, if the streamflow during the period for which the duration curve is based is a sufficiently long period of record, the statistics can be used as an indicator of probable future conditions (Searcy, 1959). In order to compare flow durations at different stations or in different basins, flow-duration estimates can be normalized by drainage area to represent a streamflow per unit area. Again, it should be noted that 
the most useful comparisons will be those based on similar lengths of record from similar hydrologic periods.

Flow durations for this report are presented in tabular form for the 5-, 10-, 25-, 50-, 75-, 90-, and 95-percent exceedances (table 2). To be consistent with the low-flow statistics, flow durations were computed based on the climatic year using daily mean flows through March 2014.

\section{Analytical Considerations}

Streamflow statistics computed at CR stations are based on historical streamflow records but can be useful for making decisions about the future if it can be reasonably assumed that the future streamflow patterns are likely to be relatively similar to historical streamflow patterns. Thus, streamflow statistics computed from records that capture a wide range of hydrologic conditions are more desirable. When a stream is influenced by regulation, techniques for estimating lowflow statistics that are similar to those used for analysis of natural streams can be applied; however, consistency in the regulation patterns also must be considered. If assessments of the historical streamflow records indicate that the regulation patterns have been relatively consistent and if the logarithm of the annual minimum flows for a given averaging period are consistent with a Pearson Type III distribution, low-flow statistics can be computed for the regulated station with the understanding that using those statistics for future planning assumes relatively similar regulation patterns will occur in the future (Riggs, 1972). Special considerations for the low-flow analyses included in this report are discussed in the following sections.

\section{Stations on the Main Stem of the Savannah River Affected by Regulation}

Three major reservoirs were constructed by the USACE on the main stem of the Savannah River: Lake Hartwell, Richard B. Russell Lake, and J. Strom Thurmond Lake (fig. 2). J. Strom Thurmond Lake began to be filled in December 1951 (Sanders and others, 1990) with construction of the dam being completed in 1954 (Georgia Department of Natural Resources, 2001). Drainage area above the dam is $6,144 \mathrm{mi}^{2}$. Richard B. Russell Lake has a drainage area of 2,900 $\mathrm{mi}^{2}$. Permanent filling of Richard B. Russell Lake began in October 1983 with construction being completed in 1985. Lake Hartwell has a drainage area of 2,088 $\mathrm{mi}^{2}$. Filling of Lake Hartwell began in 1961 and construction was completed in 1963.

Station 02189000, Savannah River near Calhoun Falls, SC, has daily mean flow data from October 1896 to April 1898, April 1899 to September 1900, April 1930 to April 1932, and April 1938 to September 1979. Low-flow analyses were done for the pre-regulated part of the record (table 2).
No analysis was made for the regulated period because of changes in regulation patterns that have occurred since 1979 and, therefore, would not likely be predictive of current or future conditions. Although the pre-regulation low-flow statistics for the USGS stations located downstream from the three USACE projects also will not be useful for estimating low-flow conditions under current or future regulated conditions, these statistics can be useful for water-resource assessments in which an understanding of pre-regulated conditions may be beneficial and, therefore, have been included in this report (table 2).

Station 02195000, Savannah River near Clarks Hill, SC, has daily mean flow data from May 1940 to June 1954, and is located downstream from J. Strom Thurmond Lake. The QAQC assessments indicated that the flow records after CY 1952, which ended on March 31, 1953, began to be influenced by construction of the dam. Consequently, low-flow analyses were made by using data through March 31, 1953, and therefore, represent pre-regulation conditions (table 2).

Station 02197000, Savannah River at Augusta, GA, has daily mean flow data from October 1883 to December 1891, January 1896 to December 1906, and January 1925 to March 2014. The station is located downstream from all three USACE projects and, therefore, the flow record represents varying degrees of regulation. A low-flow analysis representing pre-regulation conditions was made by using data through March 1951 (table 2). For the regulated period, the low-flow analysis was done using data from April 1986 to March 2014. The QAQC assessments indicated that regulation patterns were relatively stable for this period, which includes data from the period when all three upstream reservoirs were in operation.

Station 02197500, Savannah River at Burtons Ferry Bridge near Millhaven, GA, has daily mean flow data from October 1939 to September 1970, October 1982 to October 2003, and October 2004 to March 2014. Because of the relatively short period of record available for preregulation conditions, no low-flow analysis was made for that period. For the regulated period, the low-flow analysis was done by using data from April 1986 to March 2003 and April 2005 to March 2014 (table 2). The QAQC assessments indicated that regulation patterns were relatively stable for this period, which includes data from the period when all three upstream reservoirs were in operation.

Station 02198500, Savannah River near Clyo, GA, has daily mean flow data from October 1929 to September 1933 and October 1937 to March 2014. Because of the relatively short period of record available for pre-regulation conditions, no low-flow analysis was made for that period. For the regulated period, the low-flow analysis was done using data from April 1986 to March 2014 (table 2). The QAQC assessments indicated that regulation patterns were relatively stable for this period, which includes data from the period when all three upstream reservoirs were in operation. 
Station 02197344, Four Mile Creek at Road A12.2 at Savannah River Site, SC

Station 02197344 has daily mean flow record available from November 1976 to September 2002. During this period, the flows at the station were noted as being regulated by operations at the Savannah River Site (Cooney and others, 2003). On the basis of the QAQC assessments for this record, it was determined that the period after April 1986 was the most recent period for which regulation patterns were relatively stable (fig. 8). Consequently, a low-flow analysis was made for the period April 1986 to September 2002 (table 2).

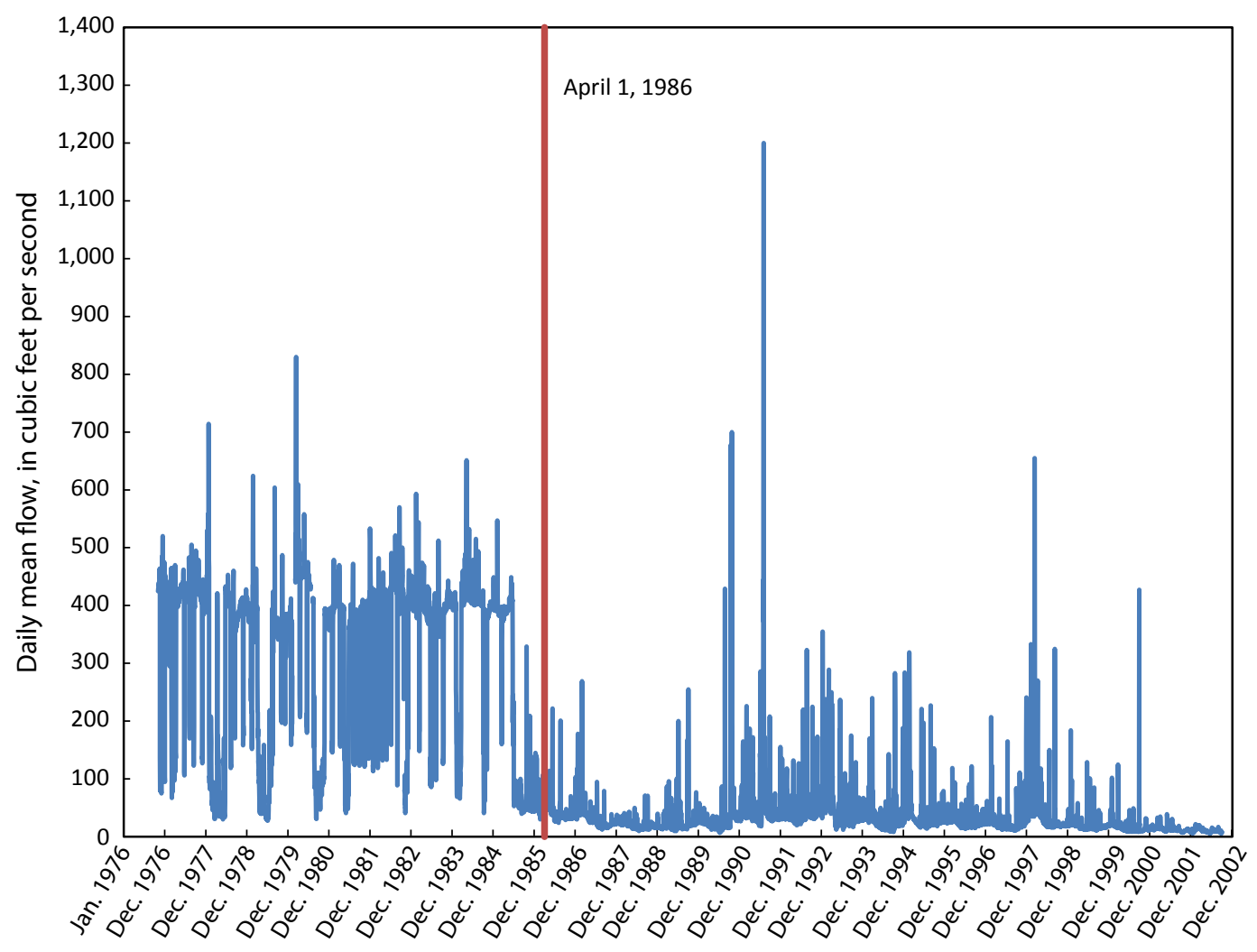

Figure 8. Daily mean flow at station 02197344, Four Mile Creek at Road A12.2 at Savannah River Site, SC, for the period November 1976 to September 2002. 
Station 02197348, Pen Branch at Road A-13.2 at Savannah River Site, SC

Station 02197348 has daily mean flow record available from November 1976 to September 2002. During this period, the flows at the station were noted as being regulated by operations at the Savannah River Site (Cooney and others, 2003). On the basis of the QAQC assessments for this record, it was determined that the period after April 1988 was the most recent period for which regulation patterns were relatively stable (fig. 9). Consequently, a low-flow analysis was made for the period April 1988 to September 2002 (table 2).

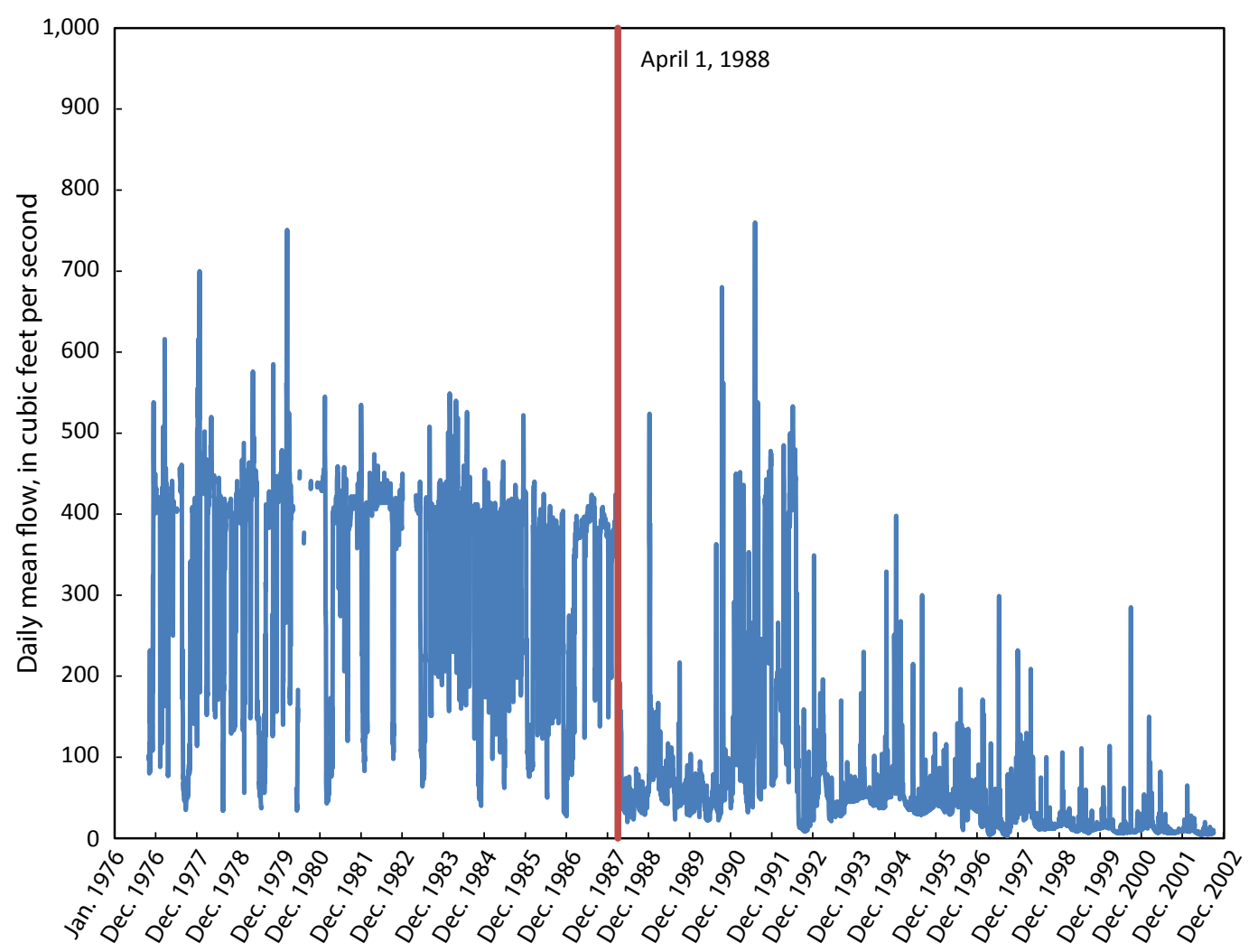

Figure 9. Daily mean flow at station 02197348, Pen Branch at Road A-13.2 at Savannah River Site, SC, for the period November 1976 to September 2002. 
Station 021973565, Steel Creek at Road A at Savannah River Site, SC

Station 021973565 has daily mean flow record available from March 1985 to September 2002. During this period, the flows at the station were noted as being regulated by operations at the Savannah River Site (Cooney and others, 2003). On the basis of a review of the temporal daily mean flow patterns along with single-mass curve analysis, it appears that flow patterns changed substantially through the period of record (fig. 10). The single-mass curve is a cumulative plot of the data over time. A substantial change in the slope of the single-mass curve indicates a change in flow patterns. With regulated flows, this often is an indication of changes in regulation patterns. On the basis of this assessment, only durations of daily flows and exceedance percentiles of annual minimum 7-day average flows were provided.

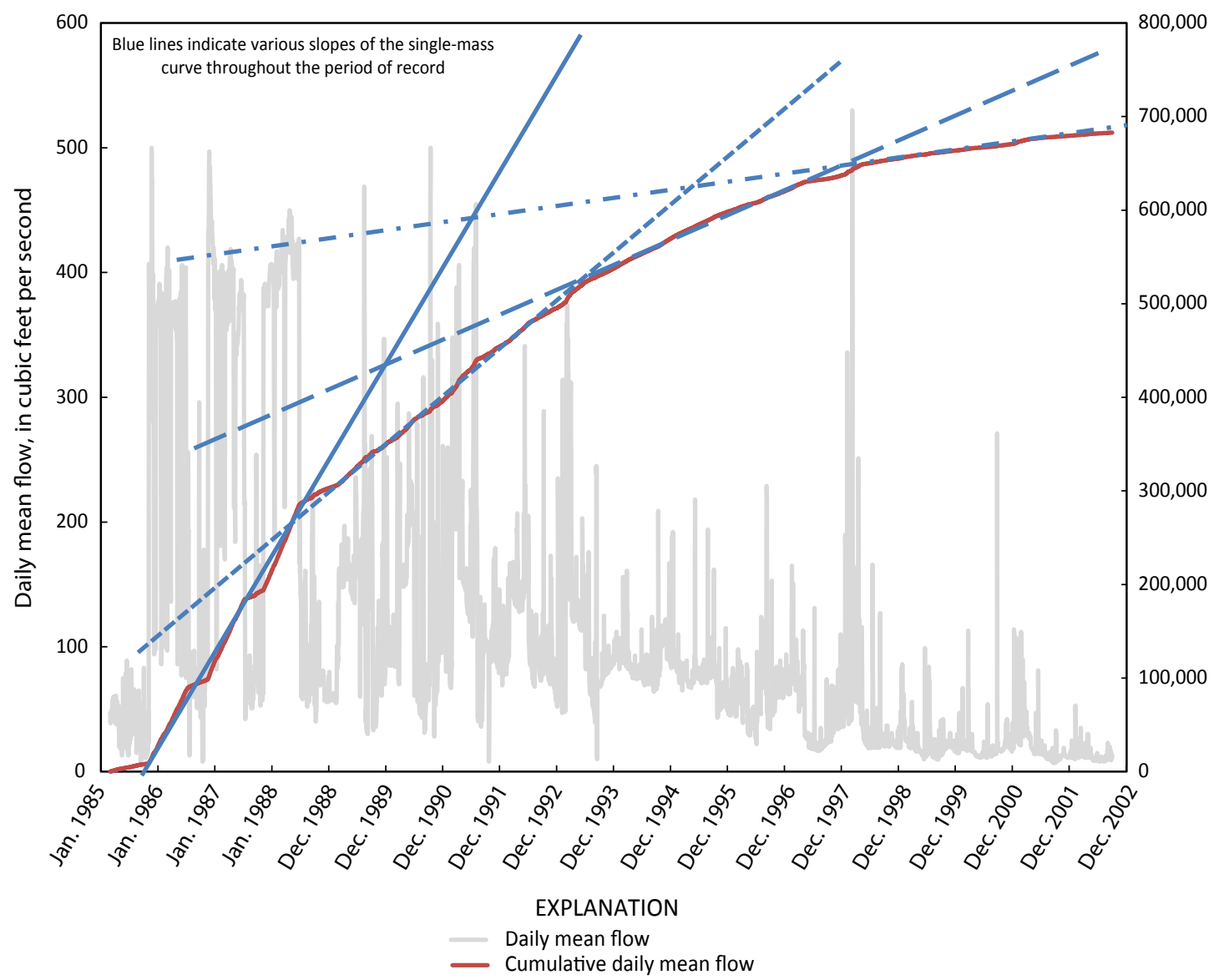

Figure 10. Daily mean flow and cumulative daily mean flow for station 021973565, Steel Creek at Road A at Savannah River Site, SC, for the period March 1985 to September 2002. 


\section{Considerations for Accuracy of Low- Flow Statistics}

With respect to streamflow statistics, the period of collected record can be thought of as a sample, or small portion of the population, which represents all possible measurements. Statistics allow for making inferences about the characteristics of the population on the basis of the samples from the population. For example, statistical measures, such as mean, standard deviation, or skew coefficient, can be described in terms of the sample and then used to make inferences about the population from which the sample was obtained. Statistical measures computed from the sample record are estimates of what the measure would be if the entire population were known and used to compute the given measure. Consequently, the accuracy of low-flow statistics at streamgaging stations is related to the lengths of records (samples from the population) upon which the statistics are based. The longer the period of record at a streamgaging station that covers a broad range of hydrologic conditions, the more accurate or reflective of long-term conditions the low-flow statistics will be.

The streamflow statistics for short-term records are much more sensitive to extreme hydrologic events than those for long-term records. As a result, streamflow statistics, whether high or low, from one 10-year period may differ significantly from another 10-year period (Dalrymple, 1960). Thus, a long-term record is always more desirable when computing streamflow statistics. To test the effect of record length and hydrologic conditions on low-flow statistics, the 7Q10 for station 02177000, Chattooga River near Clayton, GA, was computed beginning with the first 10 years of record (April 1940-March 1950) and then updated on a 5-year basis through CY 2013. Figure 11 shows the annual minimum 7-day average streamflow by climatic year for the period of record along with the computed $7 \mathrm{Q} 10$ estimates. The figure shows that the 7Q10 for the first 10 years of record, which includes the largest annual minimum 7-day average flow for the period from CY 1940 to 2013, was 146 cubic feet per second $\left(\mathrm{ft}^{3} / \mathrm{s}\right)$. By CY 1959, the 7Q10 decreased to $115 \mathrm{ft}^{3} / \mathrm{s}$ because of the addition of records collected during the historic drought period in the 1950s. The 1960s and 1970s tended to be a relatively wet period, and the $7 \mathrm{Q} 10$ increased during that time, reaching $137 \mathrm{ft}^{3} / \mathrm{s}$ in CY 1979. In CY 2007 and 2008, the two lowest annual minimum 7-day average flows of record occurred, and thus, the 7Q10 value decreased to $119 \mathrm{ft}^{3} / \mathrm{s}$ in CY 2009 . In this analysis, the percent difference between the highest $\left(146 \mathrm{ft}^{3} / \mathrm{s}\right.$ in CY 1949) and lowest (116 ft $3 / \mathrm{s}$ in CY 1954) 7Q10 is 24 percent, with percent difference computed as

$$
\text { PercentDifference }=\frac{\left|x_{1}-x_{2}\right|}{\left(\frac{x_{1}+x_{2}}{2}\right)} \times 100
$$

where

$x_{1} \quad$ is the highest 7Q10 estimate from the periods analyzed, and

$x_{2}$ is the lowest 7Q10 estimate from the periods analyzed.

To show the effect of how the 7Q10 can be influenced under a different set of hydrologic conditions and the significant influence that period of record can have on streamflow statistics, a similar analysis was done using a synthesized record of annual minimum 7-day average flows. The synthesized flows were generated by reversing the annual minimum 7-day average flows from station 02177000. Under these conditions, the first 10 years of record included the two lowest annual minimum 7-day flows for the 74 years of record used in the analysis. As shown in figure 12, the 7Q10 computed from the first 10 years of record is $87 \mathrm{ft}^{3} / \mathrm{s}$, which is a 51-percent difference from the $7 \mathrm{Q} 10$ computed on the basis of the first 10 years of record from the measured data at station 02177000 (fig. 11). Because the synthesized record began in a period that included the lowest annual minimum 7-day average flows in the 74 years of record included in the analysis, the $7 \mathrm{Q} 10$ shows a pattern of continuing to increase to the value of $122 \mathrm{ft}^{3} / \mathrm{s}$ in CY 1994. The percent difference between the highest and lowest 7Q10 computed in this analysis is 33 percent. These percent differences emphasize that, although the $7 \mathrm{Q} 10$ value at the end of the record was the same for both the measured data and the synthesized data, the intermittent values were sometimes substantially different based on a rearrangement of the hydrologic conditions (starting in an historic dry period as opposed to starting in a period that included the highest annual minimum 7-day average flow in the 74 years of record for this station). Thus, as the length of record at a streamgaging station increases, the low-flow statistics are moving toward the values that would be expected to be obtained from the population. As the period of record increases, the streamflow statistics tend to be less influenced by extreme conditions, whether wet or dry.

One additional analysis was done using seven different 10 -year periods of record at station 02177000 to show the effect that varying hydrologic conditions captured in such short records can have on the 7Q10 value at a site. The comparison was made by computing the 7Q10 at station 02177000 for the following periods (fig. 13): CY 1940 to 1949, 1950 to 1959,1960 to 1969,1970 to 1979,1980 to 1989,1990 to 1999 , and 2000 to 2009. For those seven periods, the lowest $7 \mathrm{Q} 10$ of $79 \mathrm{ft}^{3} / \mathrm{s}$ was computed for the period from CY 2000 to 2009 . The highest $7 \mathrm{Q} 10$ of $189 \mathrm{ft}^{3} / \mathrm{s}$ was computed for the period from CY 1960 to 1969 . The percent difference between those two periods is 82 percent. The percent difference between the 7Q10 computed from the complete period of record $\left(119 \mathrm{ft}^{3} / \mathrm{s}\right)$ and the $7 \mathrm{Q} 10$ computed from the period from CY 2000 to $2009\left(79 \mathrm{ft}^{3} / \mathrm{s}\right)$ is 40 percent. The percent difference between the $7 \mathrm{Q} 10$ computed from the complete period of record $\left(119 \mathrm{ft}^{3} / \mathrm{s}\right)$ and the $7 \mathrm{Q} 10$ computed from the period from CY 1960 to $1969\left(189 \mathrm{ft}^{3} / \mathrm{s}\right)$ is 45 percent. 


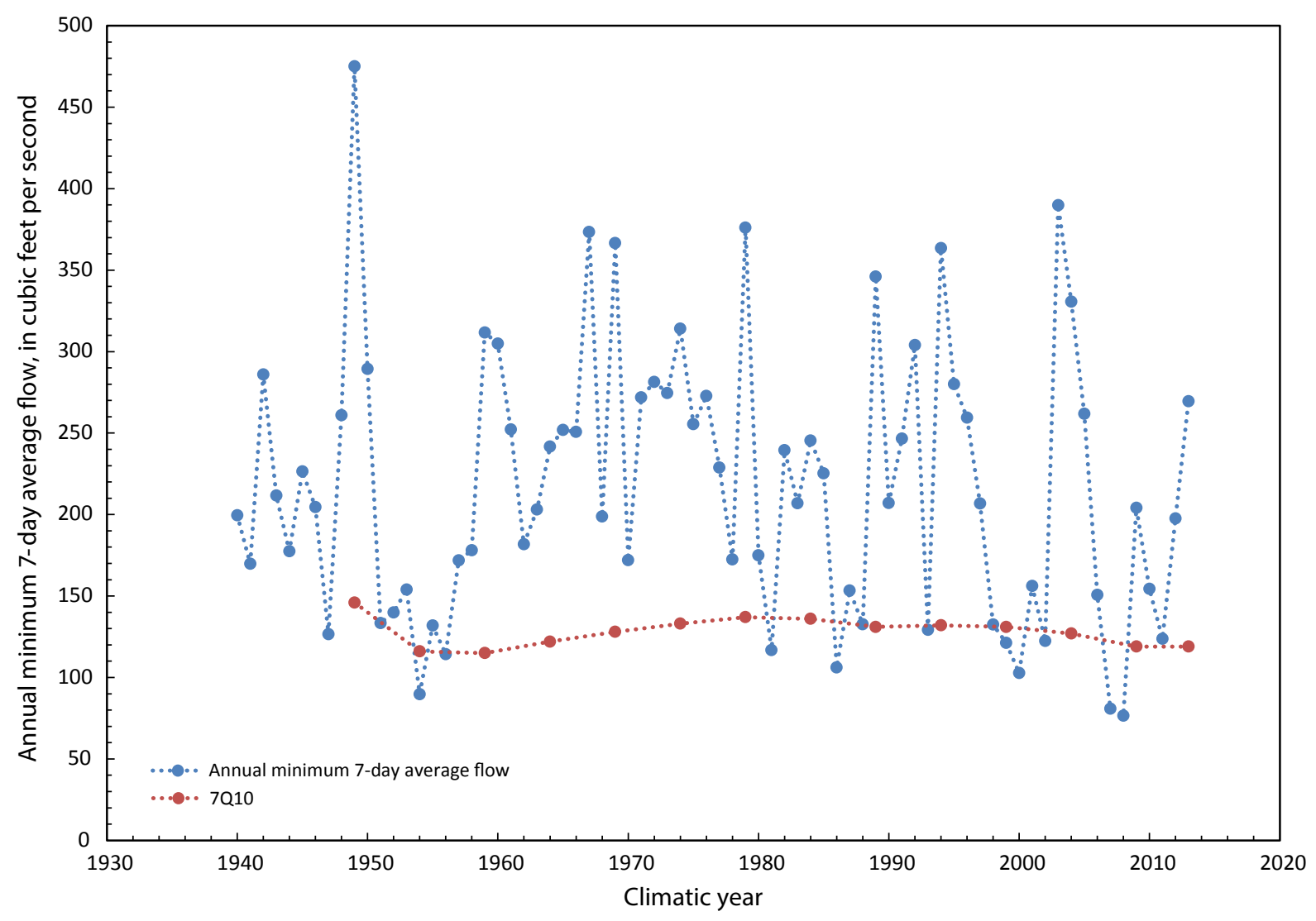

Figure 11. Annual minimum 7-day average streamflow and 7010 estimates at U.S. Geological Survey streamgaging station 02177000, Chattooga River near Clayton, GA. 


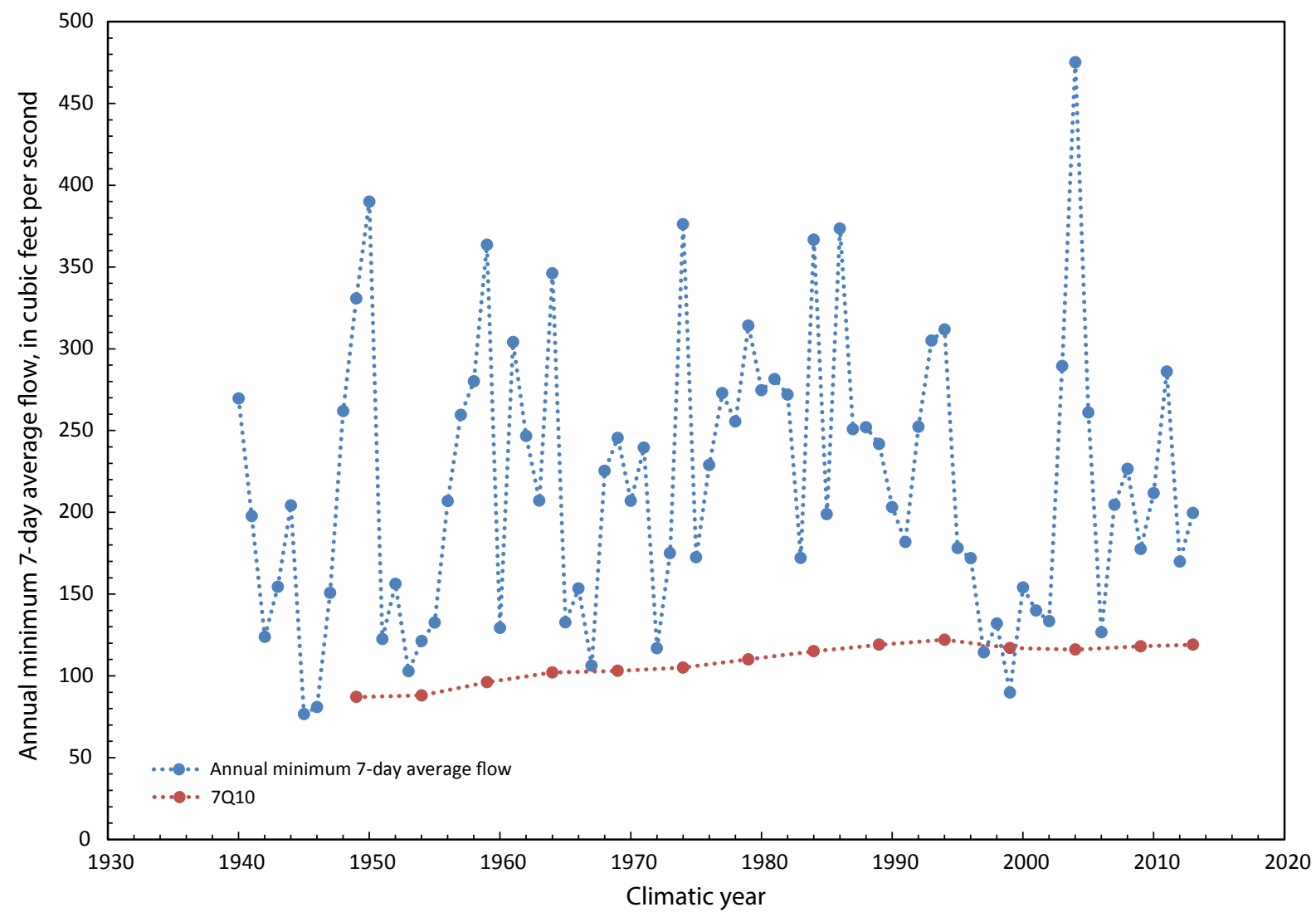

Figure 12. Annual minimum 7-day average streamflow and 7010 estimates from a synthesized dataset where the annual minimum 7-day average streamflows from U.S. Geological Survey streamgaging station 02177000, Chattooga River near Clayton, GA, were reversed for the period of record. 


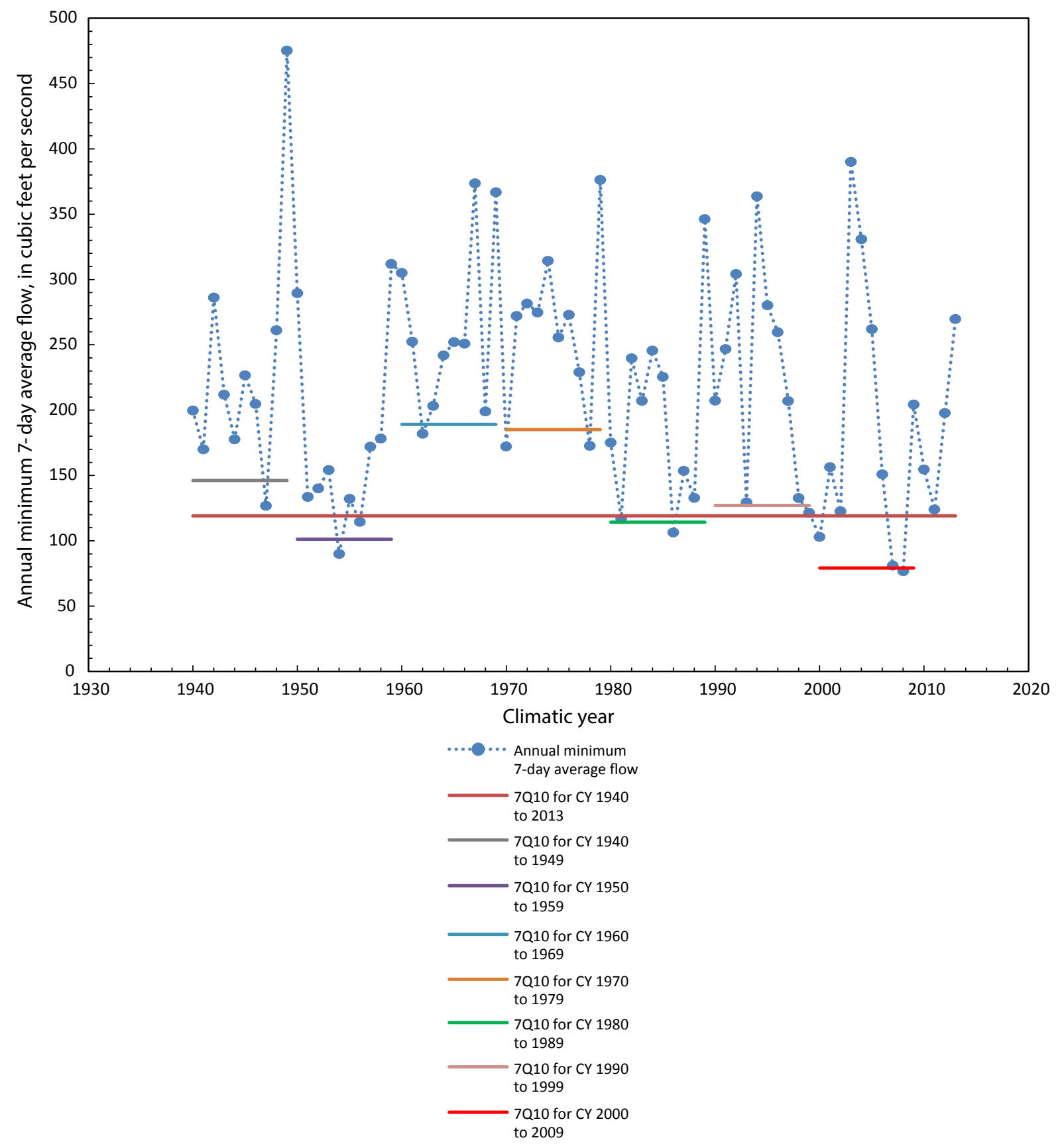

Figure 13. Annual minimum 7-day average streamflow and 7010 estimates at U.S. Geological Survey streamgaging station 02177000, Chattooga River near Clayton, GA, for seven 10-year periods: climatic years 1940 to 1949, 1950 to 1959 , 1960 to 1969,1970 to 1979, 1980 to 1989, 1990 to 1999, and 2000 to 2009. 


\section{Comparison With Previously Published Low-Flow Statistics}

Low-flow frequency statistics are influenced by length of record, hydrologic regime under which the data were collected, analytical techniques used, and other factors, such as urbanization and diversions. The last systematic update of low-flow statistics in South Carolina included data through March 1987 (the 1986 climatic year). Since that time, several substantial droughts have occurred, including one of the most severe droughts in recent history that occurred between 1998 and 2002 and a more recent drought from 2006 to 2009 (South Carolina Department of Natural Resources, 2004, 2013). Less severe droughts were reported in 1988, 1990, 1993, and 1995 (Mizzell, 2008).

Of the 28 stations included in the current study, 14 had $7 \mathrm{Q} 10$ values that had previously been published (Bloxham, 1979; Zalants, 1991b). The most recent previously published
$7 \mathrm{Q} 10$ values for these stations were compared with the current values, and the percentage change was computed as follows:

$$
\text { Percentage change }=[(\text { current 7Q10 }- \text { previous 7Q10) } /
$$$$
\text { previous 7Q10] } \times 100 \text {. }
$$

The percentage change indicates the percentage of change from the previously published 7Q10 value (table 6). The percentage changes ranged from -69.4 to 10.7 percent. The negative differences for seven stations indicate that the $7 \mathrm{Q} 10$ values decreased, and the positive differences for two stations indicate that the 7Q10 values increased. For two stations, the $7 \mathrm{Q} 10$ was unchanged as indicated by the zero percent difference. In addition, three stations located on the main stem of the Savannah River for which Bloxham (1979) computed the 7 Q10 values using records that included both unregulated and regulated data. Because the current estimates at those three stations separated the pre-regulation and post regulation data, percentage changes in the 7Q10 values were not computed.

Table 6. Differences between the annual minimum 7-day average streamflow with a 10-year recurrence interval in this report and previously published values for continuous-record streamgaging stations in the Savannah and Salkehatchie River Basins of South Carolina.

[USGS, U.S. Geological Survey; $\mathrm{ft}^{3} / \mathrm{s}$, cubic feet per second; CY, climate year; ND, not determined]

\begin{tabular}{|c|c|c|c|c|}
\hline USGS streamgaging station number and name & $\begin{array}{l}\text { Previous estimate } \\
\text { from Bloxham } \\
(1979)\left(\mathrm{ft}^{3} / \mathrm{s}\right)\end{array}$ & $\begin{array}{l}\text { Previous estimate } \\
\text { from Zalants } \\
(1991 \mathrm{~b})\left(\mathrm{ft}^{3} / \mathrm{s}\right)\end{array}$ & $\begin{array}{l}\text { Current (CY 2013) } \\
\text { estimate }\left(\mathrm{ft}^{3} / \mathrm{s}\right)\end{array}$ & $\begin{array}{c}\text { Percent difference } \\
\text { from most recent } \\
\text { estimate to current } \\
\text { estimate }\end{array}$ \\
\hline 02176500, Coosawhatchie River near Hampton, SC & 0.03 & 0.00 & 0.00 & 0.0 \\
\hline 02177000, Chattooga River near Clayton, GA & 124 & 130 & 119 & -8.5 \\
\hline 02186000, Twelvemile Creek near Liberty, SC & 33 & ND & 18 & -45.5 \\
\hline 02189000, Savannah River near Calhoun Falls, SC & 1,350 & ND & 1,060 & a \\
\hline 02192500, Little River near Mt. Carmel, SC & 7.2 & ND & 2.2 & -69.4 \\
\hline 02196000, Stevens Creek near Modoc, SC & 1.6 & 2.1 & 1.1 & -47.6 \\
\hline $\begin{array}{l}\text { 02197310, Upper Three Runs above Road C at } \\
\text { Savannah River Site, SC }\end{array}$ & ND & 100 & 99 & -1.0 \\
\hline 02197400, Lower Three Runs near Snelling, SC & ND & 16 & 16 & 0.0 \\
\hline 02198500, Savannah River near Clyo, GA & 5,800 & ND & 4,310 & $\mathrm{a}$ \\
\hline
\end{tabular}

${ }^{a}$ The estimate in Bloxham (1979) combined both unregulated and regulate flows and thus was not compared with the current estimate. 


\section{Summary}

This report, prepared in cooperation with the South Carolina Department of Health and Environmental Control, provides updated low-flow statistics at continuous-record streamgaging stations operated by the U.S. Geological Survey in the Savannah and Salkehatchie River Basins of South Carolina. Four categories of continuous-record stations were considered for analyses: (1) stations with 30 or more years of record; (2) short-term record stations with between 10 and 30 years of record; (3) stations that have between 5 and 10 years of record, and which were analyzed for a limited set of low-flow statistics by using techniques typically used in analyzing partial-record stations; and (4) regulated stations. For this investigation, record-extension techniques were not used, because conditions were not met that warranted applying such techniques. On the basis of the length of record available at the continuous-record streamgaging stations, low-flow frequency statistics were estimated for consecutive 1-, 3-, 7-, 14-, 30-, 60-, and 90-day average minimum flows with recurrence intervals of $2,5,10,20,30$, and 50 years. Additionally, daily flow durations for the 5-, 10-, 25-, 50-, 75-, 90-, and 95-percent probabilities of exceedance were computed for the stations.

Of the 28 streamgaging stations included in this study, 14 stations had low-flow statistics for the annual minimum 7-day average streamflow with a 10 -year recurrence interval (7Q10) that were previously published in U.S. Geological Survey reports. The comparison of the $7 \mathrm{Q} 10$ values for these stations showed that for nine of the stations percentage changes ranged from -69.4 to 10.7 percent; for two of the stations the percentage changes were zero, indicating no change in the 7Q10 values; and for three regulated stations comparisons of the 7Q10 were not made because of differences in the way pre-regulation and regulated data were analyzed in the current and previous studies.

\section{Selected References}

Barker, A.C., 1986, Base-flow measurements at partial-record sites on small streams in South Carolina: U.S. Geological Survey Open-File Report 86-143, 97 p.

Bloxham, W.M., 1976, Low-flow characteristics of streams in the Inner Coastal Plain of South Carolina: South Carolina Water Resources Commission Report No. 5, 41 p.

Bloxham, W.M., 1979, Low-flow frequency and flow duration of South Carolina streams: South Carolina Water Resources Commission Report No. 11, 90 p.

Bloxham, W.M., 1981, Low-flow characteristics of ungaged streams in the Piedmont and Lower Coastal Plain of South Carolina: South Carolina Water Resources Commission Report No. 14, 48 p.
Bloxham, W.M., Siple, G.E., and Cummings, T.R., 1970, Water resources of Spartanburg County, South Carolina: South Carolina Water Resources Commission Report No. 3, $112 \mathrm{p}$.

Conrads, P.A., Roehl, E.A., Jr., Daamen, R.C., Chapelle, F.H., Lowery, M.A., and Mundry, U.H., 2007, Visualization and time-series analysis of ground-water data for C-Area, Savannah River Site, South Carolina, 1984-2004: U.S. Geological Survey Scientific Investigations Report 2007-5140, 33 p.

Conrads, P.A., Roehl, E.A., Jr., Daamen, R.C., and Cook, J.B., 2013, Simulation of salinity intrusion along the Georgia and South Carolina coasts using climate-change scenarios: U.S. Geological Survey Scientific Investigations Report 2013-5036, 92 p., 5 apps.

Cooney, T.W., Drewes, P.A., Ellisor, S.W., Lanier, T.H., and Melendez, Frank, 2003, Water resources data, South Carolina, Water year 2002, U.S. Geological Survey WaterData Report SC-02-1, 683 p.

Dalrymple, Tate, 1960, Flood-frequency analyses, manual of hydrology —Part 3. Flood-flow techniques: U.S. Geological Survey Water-Supply Paper 1543-A, 80 p.

Eidson, J.P., Lacy, C.M., Nance, Luke, Hansen, W.F., Lowery, M.A., and Hurley, N.M., Jr., 2005, Development of a 10- and 12-digit hydrologic unit code numbering system for South Carolina, 2008: U.S. Department of Agriculture, Natural Resources Conservation Service, 38 p., 1 pl.

Feaster, T.D., Gotvald, A.J., and Weaver, J.C., 2009, Magnitude and frequency of rural floods in the Southeastern United States, 2006-Volume 3, South Carolina: U.S. Geological Survey Scientific Investigations Report 2009-5156, 226 p.

Feaster, T.D., and Guimaraes, W.B., 2009, Low-flow frequency and flow duration of selected South Carolina streams in the Pee Dee River Basin through March 2007: U.S. Geological Survey Open-File Report 2009-1171, 39 p.

Feaster, T.D., and Guimaraes, W.B., 2012, Low-flow frequency and flow duration of selected South Carolina streams in the Saluda, Congaree, and Edisto River Basins through March 2009: U.S. Geological Survey Open-File Report 2012-1253, 53 p.

Feaster, T.D., and Guimaraes, W.B., 2014, Low-flow frequency and flow duration of selected South Carolina streams in the Catawba-Wateree and Santee River Basins through March 2012: U.S. Geological Survey Open-File Report 2014-1113, 34 p. 
Georgia Department of Natural Resources, 2001, Savannah River Basin Management Plan 2001: Environmental Protection Division, accessed November 10, 2015, at http://epd.georgia.gov/savannah-river-basin-watershedprotection-plan.

Guimaraes, W.B., and Feaster, T.D., 2010, Low-flow frequency and flow duration of selected South Carolina streams in the Broad River Basin through March 2008: U.S. Geological Survey Open-File Report 2010-1305, 47 p.

Helsel, D.R., and Hirsch, R.M., 1992, Studies in environmental science 49-Statistical methods in water resources: Amsterdam, Elsevier Science, 529 p.

Hirsch, R.M., 1982, A comparison of four record extension techniques: Water Resources Research, v. 18, no. 4, p. 1081-1088.

Hydrology Subcommittee of the Interagency Advisory Committee on Water Data, 1982, Guidelines for determining flood frequency: U.S. Geological Survey Bulletin 17B, 183 p.

Johnson, F.A., Siple, G.E., and Cummings, T.R., 1968, A reconnaissance of the water resources of Pickens County, South Carolina: South Carolina Water Resources Commission Report No. 1, 69 p.

Kendall, M.G., 1938, A new measure of rank correlation: Biometrika, v. 30, No. 1/2, p. 81-93.

Langbein, W.B., and Iseri, K.T., 1983, General introduction and hydrologic definitions, manual of hydrology_-Part 1. General surface-water techniques (3d ed.): U.S. Geological Survey Water-Supply Paper 1541-A, 29 p.

Lins, H.F., Hirsch, R.M., and Kiang, Julie, 2010, Water-The Nations fundamental climate issue, A white paper on the U.S. Geological Survey role and capabilities: U.S. Geological Survey Circular 1347, 9 p. (Also available at http://pubs.usgs.gov/circ/1347/.)

Mizzell, Hope, 2008, Improving drought detection in the Carolinas - Evaluation of local, State, and Federal drought indicators: Columbia, S.C., Department of Geology, University of South Carolina, Ph.D. dissertation, 149 p.

National Oceanic and Atmospheric Administration, 2016, Climate at a glance, accessed on December 9, 2015, at http://www.ncdc.noaa.gov/cag/time-series/us.

Nielsen, J.P., 1999, Record extension and streamflow statistics for the Pleasant River, Maine: U.S. Geological Survey Water-Resources Investigations Report 99-4078, 22 p.

Ries, K.G., III, 1994, Estimation of low-flow duration discharges in Massachusetts: U.S. Geological Survey Water-Supply Paper 2418, 50 p.
Riggs, H.C., 1972, Low-flow investigations: U.S. Geological Survey Techniques of Water-Resources Investigations, book 4, chap. B1, 18 p.

Riggs, H.C., 1985, Streamflow characteristics: New York, Elsevier, 249 p.

Sanders, C.L., Jr., Kubik, H.E., Hoke, J.T., Jr., and Kirby, W.H., 1990, Flood frequency of the Savannah River at Augusta, Georgia: U.S. Geological Survey Water-Resources Investigations Report 90-4024, 87 p.

SAS Institute, Inc., 1989, SAS user's guide-Statistics: Cary, N.C., SAS Institute, Inc., 583 p.

Searcy, J.K., 1959, Flow-duration curves, manual of hydrology-Part 2. Low-flow techniques: U.S. Geological Survey Water-Supply Paper 1542-A, p.1-33.

South Carolina Department of Health and Environmental Control, 2010, Watershed water quality assessmentSalkehatchie River Basin: Columbia, S.C., Bureau of Water, Technical Report No. 03F-10.

South Carolina Department of Health and Environmental Control, 2009, Watersheds and TMDLs, accessed February 19, 2009, at http://www.scdhec.gov/environmental/ admin/htm/eqcpubs.htm.

South Carolina Department of Natural Resources, 2004, Hydrologic effects of the June 1998-August 2002 drought in South Carolina: Columbia, S.C., Land, Water and Conservation Division Water Resources Report 34, 49 p.

South Carolina Department of Natural Resources, 2009, South Carolina state water assessment ( $2 \mathrm{~d}$ ed.): Columbia, S.C., Land, Water and Conservation Division.

South Carolina Department of Natural Resources, 2013, South Carolina current drought status, accessed October 21, 2013, at http:/www.dnr.sc.gov/climate/sco/ Drought/drought_press_release.php.

Stallings, J.S., 1967, South Carolina streamflow characteristics - Low-flow frequency and flow duration: U.S. Geological Survey Open-File Report, 83 p.

Stedinger, J.R., and Thomas, W.O., Jr., 1985, Low-flow frequency estimation using base-flow measurements: U.S. Geological Survey Open-File Report 85-95, 22 p.

Telis, P.A., 1991, Low-flow and flow-duration characteristics of Mississippi streams: U.S. Geological Survey WaterResources Investigations Report 90-4087, 214 p.

U.S. Environmental Protection Agency, 2009, Polluted runoff (nonpoint source pollution), appendix - Case studies, accessed June 27, 2009, at http:/www.epa.gov/owow/nps/ urbanize/appendix.html. 
U.S. Geological Survey, 1979, Programs and plans-Lowflow programs: U.S. Geological Survey Office of Surface Water Technical Memorandum No. 79.06, accessed April 26, 2007, at http://water.usgs.gov/admin/memo/SW/ sw79.06.html.

U.S. Geological Survey, 1985, Programs and plans-Lowflow frequency estimation at partial-record sites: U.S. Geological Survey Office of Surface Water Technical Memorandum No. 86.02, accessed May 7, 2007, at http://water.usgs.gov/admin/memo/SW/sw86.02.html.

U.S. Geological Survey, 2013, National Streamflow Information Program (NSIP), accessed October 22, 2013, at http://water.usgs.gov/nsip/history1.html.
Zalants, M.G., 1991a, Low-flow characteristics of natural streams in the Blue Ridge, Piedmont, and upper Coastal Plain physiographic provinces of South Carolina: U.S. Geological Survey Water-Resources Investigations Report 90-4188, 92 p.

Zalants, M.G., 1991b, Low-flow frequency and flow duration of selected South Carolina streams through 1987: U.S. Geological Survey Water-Resources Investigations Report 91-4170, 87 p. 
Table 2. Low-flow statistics for continuous-record streamgaging stations in the Savannah and Salkehatchie River Basins of South Carolina.

[lat, latitude; long, longitude; ft, feet; mi, mile; mi2, square mi; ft3, cubic feet; SCDHEC, South Carolina Department of Health and Environmental Control; USGS, U.S. Geological Survey; ft3/s, cubic feet per second; water year, the 12-month period from October 1 through September 30 and is designated by the year in which the period ends]

Notes: The station low-flow statistics are presented in the following pages in numerical order by station number. See figure 2 for location of the streamgaging stations. 
STATION NAME AND NUMBER.--02175500 Salkehatchie River near Miley, SC

LOCATION_-Lat 32 $59^{\prime} 20^{\prime \prime}$, long $81^{\circ} 03^{\prime} 10^{\prime \prime}$ referenced to North American Datum of 1927, Hampton County, SC, Hydrologic Unit 03050207, on downstream side of bridge on U.S. Highway 601, 2.4 mi downstream from Savannah Creek, $3.1 \mathrm{mi}$ upstream from Hampton and Branchville Railroad bridge, 3.1 mi northwest of Miley, and at mile 68.0.

DRAINAGE AREA. $-341 \mathrm{mi}^{2}$

PERIOD OF RECORD.-February 1951 to March 2014

PERIOD OF ANALYSIS.-April 1951 to March 2014

NUMBER OF CLIMATE YEARS IN FREQUENCY ANALYSIS. -63

REMARKS.-

\section{MAGNITUDE AND FREQUENCY OF ANNUAL FLOWS}

\begin{tabular}{|c|c|c|c|c|c|c|c|}
\hline \multirow[t]{2}{*}{$\begin{array}{l}\text { Recurrence } \\
\text { intervals } \\
\text { (years) }\end{array}$} & & & age $f$ & catec & cons & & \\
\hline & 1 & 3 & 7 & 14 & 30 & 60 & 90 \\
\hline 2 & 57 & 58 & 63 & 71 & 91 & 115 & 136 \\
\hline 5 & 27 & 28 & 32 & 40 & 55 & 73 & 85 \\
\hline 10 & 16 & 18 & 21 & 28 & 41 & 56 & 65 \\
\hline 20 & 10 & 11 & 15 & 21 & 31 & 45 & 51 \\
\hline 30 & 7.6 & 8.9 & 12 & 18 & 27 & 40 & 45 \\
\hline 50 & 5.5 & 6.6 & 9.1 & 15 & 23 & 34 & 39 \\
\hline
\end{tabular}

\section{DURATION OF DAILY FLOW}

Flow equaled or exceeded for indicated percentage of time

(cubic feet per second)

\begin{tabular}{ccccccc}
\hline 5 & 10 & 25 & 50 & 75 & 90 & 95 \\
\hline 846 & 615 & 396 & 238 & 137 & 78 & 55 \\
\hline
\end{tabular}


STATION NAME AND NUMBER.--02176500 Coosawhatchie River near Hampton, SC

LOCATION.- Lat 32 $50^{\prime} 10^{\prime \prime}$, long $81^{\circ} 07^{\prime} 55^{\prime \prime}$ referenced to North American Datum of 1927, Hampton County, SC, Hydrologic Unit 03050208, near left bank on downstream side of bridge on U.S. Highway 601, 1.6 mi downstream from Black Creek, 2.5 mi southwest of Hampton, and at mile 33.6.

DRAINAGE AREA. - $203 \mathrm{mi}^{2}$

PERIOD OF RECORD.-February 1951 to March 2014

PERIOD OF ANALYSIS.-April 1951 to March 2014

NUMBER OF CLIMATE YEARS IN FREQUENCY ANALYSIS. —63

REMARKS.-

MAGNITUDE AND FREQUENCY OF ANNUAL FLOWS

\begin{tabular}{|c|c|c|c|c|c|c|c|}
\hline \multirow[t]{2}{*}{$\begin{array}{l}\text { Recurrence } \\
\text { intervals } \\
\text { (years) }\end{array}$} & & & age flc & licated & f cons & & \\
\hline & 1 & 3 & 7 & 14 & 30 & 60 & 90 \\
\hline 2 & 0.30 & 0.37 & 0.65 & 1.2 & 2.9 & 10 & 19 \\
\hline 5 & 0.00 & 0.00 & 0.00 & 0.00 & 0.23 & 0.98 & 1.9 \\
\hline 10 & 0.00 & 0.00 & 0.00 & 0.00 & 0.00 & 0.01 & 0.08 \\
\hline 20 & 0.00 & 0.00 & 0.00 & 0.00 & 0.00 & 0.00 & 0.00 \\
\hline 30 & 0.00 & 0.00 & 0.00 & 0.00 & 0.00 & 0.00 & 0.00 \\
\hline 50 & 0.00 & 0.00 & 0.00 & 0.00 & 0.00 & 0.00 & 0.00 \\
\hline
\end{tabular}

\section{DURATION OF DAILY FLOW}

Flow equaled or exceeded for indicated percentage of time

(cubic feet per second)

\begin{tabular}{ccccccc}
\hline 5 & 10 & 25 & 50 & 75 & 90 & 95 \\
\hline 640 & 434 & 199 & 57 & 11 & 1.4 & 0.0 \\
\hline
\end{tabular}


STATION NAME AND NUMBER.--02177000 Chattooga River near Clayton, GA

LOCATION.-Lat $34^{\circ} 48^{\prime} 50^{\prime \prime}$, long $83^{\circ} 18^{\prime} 22^{\prime \prime}$ referenced to North American Datum of 1927, Oconee County, SC, Hydrologic Unit 03060102, on the left bank 150 feet downstream from bridge on US 76, 2.8 miles upstream from Stekoa Creek, 9.0 miles downstream from confluence with Warwoman Creek, 9.0 miles upstream from confluence with Tallulah River, and 7.0 miles southeast of Clayton.

DRAINAGE AREA. $-207 \mathrm{mi}^{2}$

PERIOD OF RECORD.- October 1939 to March 2014

PERIOD OF ANALYSIS.-April 1940 to March 2014

NUMBER OF CLIMATE YEARS IN FREQUENCY ANALYSIS. —74

REMARKS.-

\section{MAGNITUDE AND FREQUENCY OF ANNUAL FLOWS}

\begin{tabular}{|c|c|c|c|c|c|c|c|}
\hline \multirow[t]{2}{*}{$\begin{array}{l}\text { Recurrence } \\
\text { intervals } \\
\text { (years) }\end{array}$} & & & age fl & icated & f cons & & \\
\hline & 1 & 3 & 7 & 14 & 30 & 60 & 90 \\
\hline 2 & 194 & 198 & 206 & 217 & 243 & 279 & 130 \\
\hline 5 & 137 & 140 & 145 & 153 & 169 & 196 & 143 \\
\hline 10 & 113 & 115 & 119 & 127 & 138 & 162 & 155 \\
\hline 20 & 96 & 97 & 101 & 108 & 116 & 138 & 181 \\
\hline 30 & 88 & 89 & 92 & 99 & 106 & 127 & 219 \\
\hline 50 & 79 & 80 & 83 & 89 & 96 & 115 & 313 \\
\hline
\end{tabular}

\section{DURATION OF DAILY FLOW}

Flow equaled or exceeded for indicated percentage of time

(cubic feet per second)

\begin{tabular}{ccccccc}
\hline 5 & 10 & 25 & 50 & 75 & 90 & 95 \\
\hline 1,480 & 1,160 & 800 & 519 & 330 & 216 & 174 \\
\hline
\end{tabular}


STATION NAME AND NUMBER.--02185200 Little River near Walhalla, SC

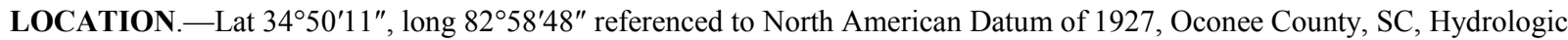
Unit 03060101, at downstream side of bridge on County Road 24, 0.5 mi. downstream from Oconee Creek, 3.5 mi south of Salem, and 6.5 mi northeast of Walhalla.

DRAINAGE AREA. $-72.0 \mathrm{mi}^{2}$

PERIOD OF RECORD.-March 1967 to September 2003

PERIOD OF ANALYSIS.-April 1967 to March 2003

NUMBER OF CLIMATE YEARS IN FREQUENCY ANALYSIS. - 36

REMARKS.-

MAGNITUDE AND FREQUENCY OF ANNUAL FLOWS

\begin{tabular}{|c|c|c|c|c|c|c|c|}
\hline \multirow[t]{2}{*}{$\begin{array}{l}\text { Recurrence } \\
\text { intervals } \\
\text { (years) }\end{array}$} & & & ge $\mathrm{f}$ & et pe & con & & \\
\hline & 1 & 3 & 7 & 14 & 30 & 60 & 90 \\
\hline 2 & 55 & 56 & 59 & 63 & 68 & 78 & 88 \\
\hline 5 & 32 & 33 & 34 & 38 & 43 & 51 & 58 \\
\hline 10 & 22 & 22 & 24 & 27 & 32 & 40 & 46 \\
\hline 20 & 15 & 16 & 17 & 20 & 25 & 31 & 37 \\
\hline 30 & 12 & 13 & 14 & 16 & 21 & 28 & 32 \\
\hline 50 & 9.5 & 10 & 11 & 13 & 18 & 24 & 28 \\
\hline
\end{tabular}

\section{DURATION OF DAILY FLOW}

Flow equaled or exceeded for indicated percentage of time

(cubic feet per second)

\begin{tabular}{ccccccc}
\hline 5 & 10 & 25 & 50 & 75 & 90 & 95 \\
\hline 385 & 292 & 204 & 138 & 90 & 61 & 46 \\
\hline
\end{tabular}


STATION NAME AND NUMBER.--02186000 Twelvemile Creek near Liberty, SC

LOCATION.-Lat $34^{\circ} 48^{\prime} 05^{\prime \prime}$, long 82 $44^{\prime} 55^{\prime \prime}$ referenced to North American Datum of 1927, Pickens County, SC, Hydrologic Unit 03060101, on State Highway 137, 0.8 mi downstream from Rices Creek, and 3.4 mi west of Liberty.

DRAINAGE AREA. $-106 \mathrm{mi}^{2}$

PERIOD OF RECORD.-August 1954 to September 1964, June 1989 to September 2001, October 2004 to March 2014

PERIOD OF ANALYSIS.-April 1955 to March 1964, April 1990 to March 2001, April 2005 to March 2014

NUMBER OF CLIMATE YEARS IN FREQUENCY ANALYSIS. - 26

REMARKS.- -

MAGNITUDE AND FREQUENCY OF ANNUAL FLOWS

\begin{tabular}{|c|c|c|c|c|c|c|c|}
\hline \multirow[t]{2}{*}{$\begin{array}{l}\text { Recurrence } \\
\text { intervals } \\
\text { (years) }\end{array}$} & \multicolumn{7}{|c|}{ (cubic feet per second) } \\
\hline & 1 & 3 & 7 & 14 & 30 & 60 & 90 \\
\hline 2 & 55 & 56 & 13 & 62 & 70 & 78 & 86 \\
\hline 5 & 31 & 31 & 15 & 36 & 42 & 48 & 54 \\
\hline 10 & 22 & 22 & 18 & 27 & 31 & 36 & 42 \\
\hline 20 & 16 & 17 & 24 & 20 & 24 & 28 & 33 \\
\hline 30 & 14 & 14 & 33 & 17 & 21 & 25 & 29 \\
\hline 50 & 11 & 12 & 58 & 15 & 17 & 21 & 25 \\
\hline
\end{tabular}

DURATION OF DAILY FLOW

Flow equaled or exceeded for indicated percentage of time

(cubic feet per second)

\begin{tabular}{ccccccc}
\hline 5 & 10 & 25 & 50 & 75 & 90 & 95 \\
\hline 434 & 306 & 202 & 133 & 88 & 57 & 41 \\
\hline
\end{tabular}


STATION NAME AND NUMBER.--02186645 Coneross Creek near Seneca, SC

LOCATION.-Lat 34³8'57", long 8259'30" referenced to North American Datum of 1927, Oconee County, SC, Hydrologic Unit 03060101 , on right bank, on downstream side of bridge on Country Road 63, approximately 0.6 mi north of junction with county roads 287 and 51 and approximately 3.0 mi southwest of Seneca.

DRAINAGE AREA. $-65.4 \mathrm{mi}^{2}$

PERIOD OF RECORD.-April 1989 to September 2003

PERIOD OF ANALYSIS.-April 1989 to March 2003

NUMBER OF CLIMATE YEARS IN FREQUENCY ANALYSIS. - 14

REMARKS.-

\section{MAGNITUDE AND FREQUENCY OF ANNUAL FLOWS}

\begin{tabular}{|c|c|c|c|c|c|c|c|}
\hline \multirow[t]{2}{*}{$\begin{array}{l}\text { Recurrence } \\
\text { intervals } \\
\text { (years) }\end{array}$} & & & ige $f$ & et pe & con & & \\
\hline & 1 & 3 & 7 & 14 & 30 & 60 & 90 \\
\hline 2 & 35 & 36 & 37 & 40 & 44 & 50 & 56 \\
\hline 5 & 17 & 18 & 19 & 21 & 25 & 30 & 34 \\
\hline 10 & 10 & 11 & 12 & 14 & 17 & 21 & 25 \\
\hline 20 & 6.0 & 6.3 & 7.2 & 8.7 & 11 & 15 & 19 \\
\hline
\end{tabular}

\section{DURATION OF DAILY FLOW}

Flow equaled or exceeded for indicated percentage of time

(cubic feet per second)

\begin{tabular}{ccccccc}
\hline 5 & 10 & 25 & 50 & 75 & 90 & 95 \\
\hline 322 & 201 & 120 & 80 & 56 & 38 & 25 \\
\hline
\end{tabular}


STATION NAME AND NUMBER.--02186699 Eighteemile Creek above Pendleton, SC

LOCATION.-Lat 34³9'32", long 8247'56" referenced to North American Datum of 1927, Anderson County, SC, Hydrologic Unit 03060101, on downstream side of bridge on County Road 229, 1.0 mi northwest of Pendleton, and 1.5 mi southeast of Clemson.

DRAINAGE AREA. $-47.0 \mathrm{mi}^{2}$

PERIOD OF RECORD.-May 1998 to July 2008

PERIOD OF ANALYSIS.-May 1998 to March 2008

NUMBER OF CLIMATE YEARS IN FREQUENCY ANALYSIS. - 10

REMARKS.-

\section{MAGNITUDE AND FREQUENCY OF ANNUAL FLOWS}

\begin{tabular}{|c|c|c|c|c|c|c|c|}
\hline \multirow[t]{2}{*}{$\begin{array}{l}\text { Recurrence } \\
\text { intervals } \\
\text { (years) }\end{array}$} & & & age $f$ & icate & con & & \\
\hline & 1 & 3 & 7 & 14 & 30 & 60 & 90 \\
\hline 2 & 15 & 16 & 17 & 18 & 21 & 24 & 28 \\
\hline 5 & 7.7 & 8.0 & 8.4 & 9.4 & 13 & 16 & 18 \\
\hline 10 & 5.1 & 5.3 & 5.6 & 6.4 & 9.5 & 13 & 15 \\
\hline 20 & 3.5 & 3.7 & 3.9 & 4.5 & 7.3 & 11 & 12 \\
\hline
\end{tabular}

\section{DURATION OF DAILY FLOW}

Flow equaled or exceeded for indicated percentage of time

(cubic feet per second)

\begin{tabular}{ccccccc}
\hline 5 & 10 & 25 & 50 & 75 & 90 & 95 \\
\hline 114 & 85 & 60 & 42 & 28 & 18 & 14 \\
\hline
\end{tabular}


STATION NAME AND NUMBER.--02187910 Rocky River near Starr, SC

LOCATION.-Lat 34²2'59", long 82³4'39" referenced to North American Datum of 1927, Anderson County, SC, Hydrologic Unit 03060103, at downstream side of bridge on StateRoad 244, 0.5 mi upstream from Beaver Creek, 2.5 mi upstream of Secession Lake, and 6.7 mi east of Starr.

DRAINAGE AREA. $-111 \mathrm{mi}^{2}$

PERIOD OF RECORD.-May 1989 to February 1996, October 1996 to October 2001, February 2003 to March 2004, October 2004 to March 2014

PERIOD OF ANALYSIS.-April 1990 to March 1995, April 1997 to March 2001, March 2005 to April 2014

NUMBER OF CLIMATE YEARS IN FREQUENCY ANALYSIS. -18

REMARKS.-Broadway Lake is located on Broadway Creek, which is a tributary to Rocky River, was completed in 1940, and has a drainage area of 44.7 square miles.

\section{MAGNITUDE AND FREQUENCY OF ANNUAL FLOWS}

\begin{tabular}{|c|c|c|c|c|c|c|c|}
\hline \multirow[t]{2}{*}{$\begin{array}{l}\text { Recurrence } \\
\text { intervals } \\
\text { (years) }\end{array}$} & & & ige fl & catec & cons & & \\
\hline & 1 & 3 & 7 & 14 & 30 & 60 & 90 \\
\hline 2 & 19 & 19 & 20 & 23 & 27 & 33 & 37 \\
\hline 5 & 9.4 & 9.8 & 10 & 12 & 15 & 19 & 23 \\
\hline 10 & 6.4 & 6.7 & 7.3 & 8.6 & 11 & 14 & 17 \\
\hline 20 & 4.7 & 4.9 & 5.4 & 6.4 & 8.2 & 11 & 13 \\
\hline
\end{tabular}

\section{DURATION OF DAILY FLOW}

Flow equaled or exceeded for indicated percentage of time

(cubic feet per second)

\begin{tabular}{ccccccc}
\hline 5 & 10 & 25 & 50 & 75 & 90 & 95 \\
\hline 340 & 220 & 128 & 80 & 49 & 26 & 17 \\
\hline
\end{tabular}


STATION NAME AND NUMBER.--02189000 Savannah River near Calhoun Falls, SC

LOCATION.-Lat 3404'15”, long 82³8’30" referenced to North American Datum of 1927, Abbeville County, SC, Hydrologic Unit 03060103, $150 \mathrm{ft}$ upstream from State Highway 72, $1.0 \mathrm{mi}$ downstream from Seaboard Coast Line Railroad, 1.5 mi downstream from Rocky River, and at mile 279.7.

DRAINAGE AREA. $-2,876 \mathrm{mi}^{2}$

PERIOD OF RECORD.- October 1896 to April 1898, April 1899 to September 1900, April 1930 to April 1932, April 1938 to September 1979

PERIOD OF ANALYSIS.-April 1897 to March 1898, April 1899 to March 1900, April 1930 to March 1932, April 1938 to March 1961

NUMBER OF CLIMATE YEARS IN FREQUENCY ANALYSIS. —-27

REMARKS.- - Regulated since 1962 by Lake Hartwell Dam and since 1985 by Richard B. Russell Dam. Results represent preregulation conditions.

\section{MAGNITUDE AND FREQUENCY OF ANNUAL FLOWS}

\begin{tabular}{|c|c|c|c|c|c|c|c|}
\hline \multirow[t]{2}{*}{$\begin{array}{l}\text { Recurrence } \\
\text { intervals } \\
\text { (years) }\end{array}$} & & & rage flo & eet per & of conse & ays & \\
\hline & 1 & 3 & 7 & 14 & 30 & 60 & 90 \\
\hline 2 & 1,190 & 1,420 & 1,780 & 1,920 & 2,070 & 2,330 & 2,470 \\
\hline 5 & 847 & 1,010 & 1,290 & 1,410 & 1,620 & 1,810 & 1,950 \\
\hline 10 & 711 & 843 & 1,060 & 1,180 & 1,430 & 1,590 & 1,740 \\
\hline 20 & 617 & 726 & 897 & 1,010 & 1,280 & 1,440 & 1,600 \\
\hline 30 & 573 & 671 & 818 & 933 & 1,220 & 1,360 & 1,530 \\
\hline
\end{tabular}

\section{DURATION OF DAILY FLOW}

Flow equaled or exceeded for indicated percentage of time

(cubic feet per second)

\begin{tabular}{ccccccc}
\hline 5 & 10 & 25 & 50 & 75 & 90 & 95 \\
\hline 11,000 & 8,320 & 5,580 & 3,750 & 2,640 & 1,960 & 1,640 \\
\end{tabular}


STATION NAME AND NUMBER.--02192500 Little River near Mount Carmel, SC

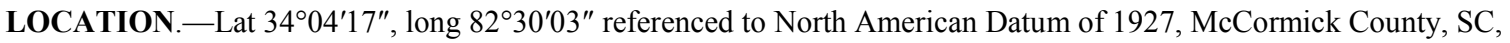

Hydrologic Unit 03060103, on downstream side of bridge, on State Road 40 (Island Ford Road), 2.9 mi upstream from Calhoun Creek, and 4.6 mi north of Mount Carmel.

DRAINAGE AREA. $-217 \mathrm{mi}^{2}$

PERIOD OF RECORD.-January 1940 to September 1970, September 1986 to October 2003, October 2004 to March 2014

PERIOD OF ANALYSIS.-April 1940 to March 1970, April 1987 to March 2003, March 2005 to April 2014

NUMBER OF CLIMATE YEARS IN FREQUENCY ANALYSIS. — 55

REMARKS.-

\section{MAGNITUDE AND FREQUENCY OF ANNUAL FLOWS}

\begin{tabular}{|c|c|c|c|c|c|c|c|}
\hline \multirow[t]{2}{*}{$\begin{array}{l}\text { Recurrence } \\
\text { intervals } \\
\text { (years) }\end{array}$} & & & (cubic feet per second) & icated & fcons & & \\
\hline & 1 & 3 & 7 & 14 & 30 & 60 & 90 \\
\hline 2 & 21 & 21 & 24 & 27 & 33 & 49 & 51 \\
\hline 5 & 5.0 & 5.4 & 6.1 & 7.5 & 10 & 15 & 18 \\
\hline 10 & 1.8 & 1.9 & 2.2 & 2.9 & 4.1 & 5.2 & 8.4 \\
\hline 20 & 0.57 & 0.64 & 0.75 & 1.0 & 1.6 & 1.7 & 4.0 \\
\hline 30 & 0.23 & 0.26 & 0.32 & 0.45 & 0.73 & 0.84 & 2.5 \\
\hline 50 & 0.02 & 0.02 & 0.02 & 0.04 & 0.07 & 0.36 & 1.5 \\
\hline
\end{tabular}

\section{DURATION OF DAILY FLOW}

Flow equaled or exceeded for indicated percentage of time

(cubic feet per second)

\begin{tabular}{ccccccc}
\hline 5 & 10 & 25 & 50 & 75 & 90 & 95 \\
\hline 582 & 343 & 182 & 96 & 52 & 26 & 12 \\
\hline
\end{tabular}


STATION NAME AND NUMBER.--02192830 Blue Hill Creek at Abbeville, SC

LOCATION.-Lat $34^{\circ} 10^{\prime} 03^{\prime \prime}$, long 82²2'17”' referenced to North American Datum of 1927, Abbeville County, SC, Hydrologic Unit 03060103, on downstream side of footbridge behind the Milliken waste water treatment facility, $0.3 \mathrm{mi}$ downstream of SC Highway 72, and 1.4 mi upstream of Parker Creek.

DRAINAGE AREA. $-3.24 \mathrm{mi}^{2}$

PERIOD OF RECORD.-February 1998 to August 2008

PERIOD OF ANALYSIS.-April 1998 to March 2008

NUMBER OF CLIMATE YEARS IN FREQUENCY ANALYSIS. - 10

REMARKS.- -

\section{MAGNITUDE AND FREQUENCY OF ANNUAL FLOWS}

\begin{tabular}{|c|c|c|c|c|c|c|c|}
\hline \multirow[t]{2}{*}{$\begin{array}{l}\text { Recurrence } \\
\text { intervals } \\
\text { (years) }\end{array}$} & & & age flc & eet per & f cons & & \\
\hline & 1 & 3 & 7 & 14 & 30 & 60 & 90 \\
\hline 2 & 0.27 & 0.30 & 0.34 & 0.37 & 0.50 & 0.83 & 1.0 \\
\hline 5 & 0.11 & 0.10 & 0.15 & 0.17 & 0.26 & 0.42 & 0.54 \\
\hline 10 & 0.00 & 0.05 & 0.09 & 0.11 & 0.18 & 0.27 & 0.36 \\
\hline 20 & 0.00 & 0.03 & 0.06 & 0.08 & 0.13 & 0.18 & 0.25 \\
\hline
\end{tabular}

\section{DURATION OF DAILY FLOW}

Flow equaled or exceeded for indicated percentage of time

(cubic feet per second)

\begin{tabular}{ccccccc}
\hline 5 & 10 & 25 & 50 & 75 & 90 & 95 \\
\hline 10 & 5.8 & 2.5 & 1.5 & 0.83 & 0.47 & 0.30 \\
\hline
\end{tabular}


STATION NAME AND NUMBER.--02195000 Savannah River near Clarks Hill, SC

LOCATION.-Lat 3338'40”, long 82¹2'05" referenced to North American Datum of 1927, Columbia County, GA, Hydrologic Unit 03060103, on right bank 1.2 miles downstream from J. Strom Thurmond Dam, 2.4 mi southwest of Clarks Hill, 2.5 mi upstream from Kiokee Creek, and at mile 221.1 upstream from Savannah, GA.

DRAINAGE AREA. - $6,150 \mathrm{mi}^{2}$

PERIOD OF RECORD.--May 1940 to June 1954

PERIOD OF ANALYSIS.-April 1941 to March 1953

NUMBER OF CLIMATE YEARS IN FREQUENCY ANALYSIS. - 12

REMARKS.- - Regulated since 1954 by J. Strom Thurmond Dam and since 1986 by Richard B. Russell Dam. Results represent pre-regulation conditions.

\section{MAGNITUDE AND FREQUENCY OF ANNUAL FLOWS}

\begin{tabular}{|c|c|c|c|c|c|c|c|}
\hline \multirow[t]{2}{*}{$\begin{array}{l}\text { Recurrence } \\
\text { intervals } \\
\text { (years) }\end{array}$} & & Lo & rage flo & dicated & of conse & lays & \\
\hline & 1 & 3 & 7 & 14 & 30 & 60 & 90 \\
\hline 2 & 1,940 & 2,230 & 2,650 & 2,980 & 3,300 & 3,750 & 3,980 \\
\hline 5 & 1,480 & 1,810 & 2,110 & 2,400 & 2,690 & 2,960 & 3,100 \\
\hline 10 & 1,330 & 1,690 & 1,920 & 2,190 & 2,470 & 2,670 & 2,770 \\
\hline 20 & 1,230 & 1,620 & 1,800 & 2,060 & 2,330 & 2,470 & 2,540 \\
\hline
\end{tabular}

\section{DURATION OF DAILY FLOW}

Flow equaled or exceeded for indicated percentage of time

(cubic feet per second)

\begin{tabular}{ccccccc}
\hline 5 & 10 & 25 & 50 & 75 & 90 & 95 \\
\hline 23,200 & 15,300 & 9,480 & 5,830 & 3,960 & 3,060 & 2,600 \\
\hline
\end{tabular}


STATION NAME AND NUMBER.--02196000 Stevens Creek near Modoc, SC

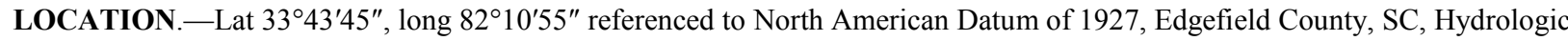
Unit 03060107, on left bank, $15 \mathrm{ft}$ upstream of bridge on State Highway 23, 1.4 mi east of Modoc, and 3.2 mi downstream from Turkey Creek.

DRAINAGE AREA. $-545 \mathrm{mi}^{2}$

PERIOD OF RECORD.- November 1929 to September 1931, February 1940 to September 1978, November 1983 to March 2014

PERIOD OF ANALYSIS.-April 1930 to March 1931, April 1940 to March 1978, April 1984 to March 2014

NUMBER OF CLIMATE YEARS IN FREQUENCY ANALYSIS. —69

REMARKS.-

\section{MAGNITUDE AND FREQUENCY OF ANNUAL FLOWS}

\begin{tabular}{|c|c|c|c|c|c|c|c|}
\hline \multirow[t]{2}{*}{$\begin{array}{l}\text { Recurrence } \\
\text { intervals } \\
\text { (years) }\end{array}$} & & & age flo & icated & f conse & & \\
\hline & 1 & 3 & 7 & 14 & 30 & 60 & 90 \\
\hline 2 & 5.0 & 5.9 & 7.5 & 9.5 & 14 & 30 & 36 \\
\hline 5 & 1.4 & 1.7 & 2.4 & 3.1 & 5.0 & 9.3 & 12 \\
\hline 10 & 0.63 & 0.77 & 1.1 & 1.5 & 2.4 & 3.5 & 6.0 \\
\hline 20 & 0.28 & 0.34 & 0.50 & 0.70 & 1.1 & 1.3 & 3.1 \\
\hline 30 & 0.16 & 0.20 & 0.29 & 0.42 & 0.67 & 0.70 & 2.1 \\
\hline 50 & 0.06 & 0.07 & 0.11 & 0.16 & 0.25 & 0.32 & 1.3 \\
\hline
\end{tabular}

DURATION OF DAILY FLOW

Flow equaled or exceeded for indicated percentage of time

(cubic feet per second)

\begin{tabular}{ccccccc}
\hline 5 & 10 & 25 & 50 & 75 & 90 & 95 \\
\hline 1,500 & 734 & 269 & 89 & 29 & 11 & 5.6 \\
\hline
\end{tabular}


STATION NAME AND NUMBER.--02196250 Horn Creek near Colliers, SC

LOCATION.-Lat 3342'55", long 81 ${ }^{\circ} 56^{\prime 2} 3^{\prime \prime}$ referenced to North American Datum of 1927, Edgefield County, SC, Hydrologic Unit 03060107 , on county road 76 bridge 5.1 miles south of Edgefield and 3.5 miles northeast of Ropers Crossroads.

DRAINAGE AREA. $-13.9 \mathrm{mi}^{2}$

PERIOD OF RECORD.—October 1980 to September 1994

PERIOD OF ANALYSIS. - April 1981 to March 1994

NUMBER OF CLIMATE YEARS IN FREQUENCY ANALYSIS. - -13

REMARKS.-

\section{MAGNITUDE AND FREQUENCY OF ANNUAL FLOWS}

\begin{tabular}{|c|c|c|c|c|c|c|c|}
\hline \multirow[t]{2}{*}{$\begin{array}{l}\text { Recurrence } \\
\text { intervals } \\
\text { (years) }\end{array}$} & & & age flo & icated & con & & \\
\hline & 1 & 3 & 7 & 14 & 30 & 60 & 90 \\
\hline 2 & 2.2 & 2.3 & 2.4 & 2.6 & 3.1 & 3.9 & 4.4 \\
\hline 5 & 1.3 & 1.3 & 1.4 & 1.5 & 2.0 & 2.5 & 3.0 \\
\hline 10 & 0.94 & 0.96 & 1.0 & 1.1 & 1.5 & 1.9 & 2.4 \\
\hline 20 & 0.72 & 0.74 & 0.76 & 0.85 & 1.2 & 1.5 & 2.0 \\
\hline
\end{tabular}

\section{DURATION OF DAILY FLOW}

Flow equaled or exceeded for indicated percentage of time

(cubic feet per second)

\begin{tabular}{ccccccc}
\hline 5 & 10 & 25 & 50 & 75 & 90 & 95 \\
\hline 40 & 25 & 15 & 8.3 & 5.3 & 3.4 & 2.4 \\
\hline
\end{tabular}


STATION NAME AND NUMBER.--02196689 Little Horse Creek near Graniteville, SC

LOCATION.-Lat 3333'49", long 81 ${ }^{\circ} 52^{\prime 2} 7^{\prime \prime}$ referenced to North American Datum of 1927, Aiken County, SC, Hydrologic Unit 03060106, on County Road 104, 0.5 mi downstream from Hightower Creek, 1.0 mi upstream of Sudlow Lake, and $3.8 \mathrm{mi}$ west of Graniteville.

DRAINAGE AREA. $-26.6 \mathrm{mi}^{2}$

PERIOD OF RECORD.-October 1989 to December 1999, March 2000 to April 2001

PERIOD OF ANALYSIS.-April 1990 to March 1999, April 2000 to March 2001

NUMBER OF CLIMATE YEARS IN FREQUENCY ANALYSIS. - 10

REMARKS.-

MAGNITUDE AND FREQUENCY OF ANNUAL FLOWS

\begin{tabular}{|c|c|c|c|c|c|c|c|}
\hline \multirow{2}{*}{$\begin{array}{l}\text { Recurrence } \\
\text { intervals } \\
\text { (years) }\end{array}$} & \multicolumn{7}{|c|}{ Lowest average flow for indicated number of consecutive days } \\
\hline & 1 & 3 & 7 & 14 & 30 & 60 & 90 \\
\hline 2 & 9.4 & 12 & 14 & 15 & 18 & 20 & 22 \\
\hline 5 & 6.0 & 9.0 & 10 & 12 & 14 & 16 & 18 \\
\hline 10 & 4.7 & 7.7 & 9.1 & 10 & 12 & 14 & 16 \\
\hline 20 & 3.8 & 6.8 & 8.2 & 9.2 & 11 & 13 & 15 \\
\hline
\end{tabular}

\section{DURATION OF DAILY FLOW}

Flow equaled or exceeded for indicated percentage of time

(cubic feet per second)

\begin{tabular}{ccccccc}
\hline 5 & 10 & 25 & 50 & 75 & 90 & 95 \\
\hline 63 & 52 & 39 & 29 & 22 & 16 & 13 \\
\hline
\end{tabular}


STATION NAME AND NUMBER.--02197000 Savannah River at Augusta, GA

LOCATION.-Lat 3322'25", long 8156'35" referenced to North American Datum of 1927, Richmond County, GA, Hydrologic Unit 03060106, at New Savannah Bluff lock and dam, 0.2 mi upstream from Butler Creek, 12.0 mi downstream from Augusta, and at mile 187.4.

DRAINAGE AREA.-7,510 $\mathrm{mi}^{2}$

PERIOD OF RECORD.-October 1883 to December 1891, January 1896 to December 1906, January 1925 to March 2014

PERIOD OF ANALYSIS.-April 1884 to March 1891, April 1896 to March 1906, April 1925 to March 1951

NUMBER OF CLIMATE YEARS IN FREQUENCY ANALYSIS. - 43

REMARKS.- - Regulated since about 1954 by J.Strom Thurmond Lake, 1962 by Lake Hartwell, and 1985 by Richard B. Russell Lake. The low-flow statistics represent the pre-regulation period.

MAGNITUDE AND FREQUENCY OF ANNUAL FLOWS

\begin{tabular}{|c|c|c|c|c|c|c|c|}
\hline \multirow[t]{2}{*}{$\begin{array}{l}\text { Recurrence } \\
\text { intervals } \\
\text { (years) }\end{array}$} & & & rage flo & licated & f conse & & \\
\hline & 1 & 3 & 7 & 14 & 30 & 60 & 90 \\
\hline 2 & 2,320 & 2,640 & 2,920 & 3,190 & 3,560 & 4,080 & 4,520 \\
\hline 5 & 1,650 & 1,940 & 2,170 & 2,360 & 2,650 & 3,020 & 3,310 \\
\hline 10 & 1,390 & 1,650 & 1,860 & 2,010 & 2,250 & 2,550 & 2,780 \\
\hline 20 & 1,200 & 1,440 & 1,630 & 1,760 & 1,960 & 2,210 & 2,390 \\
\hline 30 & 1,110 & 1,340 & 1,520 & 1,640 & 1,820 & 2,050 & 2,200 \\
\hline 50 & 1,020 & 1,240 & 1,400 & 1,510 & 1,670 & 1,870 & 2,000 \\
\hline
\end{tabular}

DURATION OF DAILY FLOW

Flow equaled or exceeded for indicated percentage of time

(cubic feet per second)

\begin{tabular}{ccccccc}
\hline 5 & 10 & 25 & 50 & 75 & 90 & 95 \\
\hline 29,800 & 20,100 & 10,900 & 6,830 & 4,490 & 3,240 & 2,690 \\
\hline
\end{tabular}


STATION NAME AND NUMBER.--02197000 Savannah River at Augusta, GA

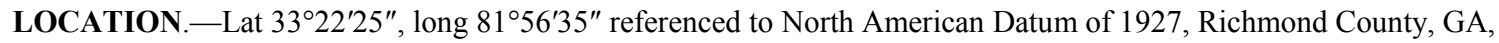
Hydrologic Unit 03060106, at New Savannah Bluff lock and dam, 0.2 mi upstream from Butler Creek, 12.0 mi downstream from Augusta, and at mile 187.4.

DRAINAGE AREA. $-7,510 \mathrm{mi}^{2}$

PERIOD OF RECORD.- October 1883 to December 1891, January 1896 to December 1906, January 1925 to March 2014

PERIOD OF ANALYSIS.-April 1986 to March 2014

NUMBER OF CLIMATE YEARS IN FREQUENCY ANALYSIS. —-28

REMARKS.- - Regulated since about 1954 by J.Strom Thurmond Lake, 1962 by Lake Hartwell, and 1985 by Richard B. Russell Lake. The low-flow statistics represent the most recent period of relatively stable regulation.

\section{MAGNITUDE AND FREQUENCY OF ANNUAL FLOWS}

\begin{tabular}{|c|c|c|c|c|c|c|c|}
\hline \multirow{2}{*}{$\begin{array}{l}\text { Recurrence } \\
\text { intervals } \\
\text { (years) }\end{array}$} & \multicolumn{7}{|c|}{ Lowest average flow for indicated number of consecutive days } \\
\hline & 1 & 3 & 7 & 14 & 30 & 60 & 90 \\
\hline 2 & 3,790 & 3,990 & 4,190 & 4,370 & 4,560 & 4,780 & 4,990 \\
\hline 5 & 3,410 & 3,570 & 3,700 & 3,810 & 3,950 & 4,090 & 4,230 \\
\hline 10 & 3,240 & 3,360 & 3,460 & 3,540 & 3,680 & 3,780 & 3,890 \\
\hline 20 & 3,110 & 3,200 & 3,270 & 3,340 & 3,470 & 3,540 & 3,640 \\
\hline 30 & 3,050 & 3,110 & 3,170 & 3,230 & 3,360 & 3,420 & 3,520 \\
\hline
\end{tabular}

\section{DURATION OF DAILY FLOW}

Flow equaled or exceeded for indicated percentage of time

(cubic feet per second)

\begin{tabular}{ccccccc}
\hline 5 & 10 & 25 & 50 & 75 & 90 & 95 \\
\hline 23,200 & 15,700 & 8,400 & 5,600 & 4,430 & 4,020 & 3,830 \\
\hline
\end{tabular}


STATION NAME AND NUMBER.--02197300 Upper Three Runs near New Ellenton, SC

LOCATION.-Lat 3323'05", long 81 $37^{\prime} 00^{\prime \prime}$ referenced to North American Datum of 1927, Aiken County, SC, Hydrologic Unit 03060106, at downstream side of bridge on U.S. Highway 278, $0.4 \mathrm{mi}$ upstream from Johnson Fork Creek, and $4.6 \mathrm{mi}$ southeast of New Ellenton.

DRAINAGE AREA. $-87.0 \mathrm{mi}^{2}$

PERIOD OF RECORD.- - June 1966 to September 2002

PERIOD OF ANALYSIS.-April 1967 to March 2002

NUMBER OF CLIMATE YEARS IN FREQUENCY ANALYSIS. - 35

REMARKS.-

MAGNITUDE AND FREQUENCY OF ANNUAL FLOWS

\begin{tabular}{|c|c|c|c|c|c|c|c|}
\hline \multirow[t]{2}{*}{$\begin{array}{l}\text { Recurrence } \\
\text { intervals } \\
\text { (years) }\end{array}$} & & & ge fl & catec & cons & & \\
\hline & 1 & 3 & 7 & 14 & 30 & 60 & 90 \\
\hline 2 & 76 & 77 & 79 & 81 & 85 & 89 & 91 \\
\hline 5 & 65 & 66 & 67 & 70 & 73 & 77 & 79 \\
\hline 10 & 59 & 60 & 62 & 64 & 67 & 71 & 73 \\
\hline 20 & 55 & 56 & 57 & 59 & 63 & 66 & 68 \\
\hline 30 & 52 & 53 & 55 & 57 & 61 & 63 & 66 \\
\hline 50 & 50 & 51 & 53 & 54 & 58 & 60 & 63 \\
\hline
\end{tabular}

\section{DURATION OF DAILY FLOW}

Flow equaled or exceeded for indicated percentage of time

(cubic feet per second)

\begin{tabular}{ccccccc}
\hline 5 & 10 & 25 & 50 & 75 & 90 & 95 \\
\hline 149 & 130 & 114 & 100 & 86 & 72 & 67 \\
\hline
\end{tabular}


STATION NAME AND NUMBER.—02197309 Tims Branch at Road C at Savannah River Site, SC

LOCATION.-Lat 3317'13", long 8141'49" referenced to North American Datum of 1927, Aiken County, SC, Hydrologic Unit 03060106, on left upstream end of metal culvert, $30 \mathrm{ft}$ northeast of SRS Road C and $300 \mathrm{ft}$ northwest of Upper Three Runs Creek, at Savannah River Site.

DRAINAGE AREA. $-17.5 \mathrm{mi}^{2}$

PERIOD OF RECORD.-March 1974 to September 1982, October 1984 to September 1996

PERIOD OF ANALYSIS.-April 1974 to March 1982, April 1985 to March 1996

NUMBER OF CLIMATE YEARS IN FREQUENCY ANALYSIS. - 17

REMARKS.-Flow regulated by Savannah River Site operations.

\section{MAGNITUDE AND FREQUENCY OF ANNUAL FLOWS}

\begin{tabular}{|c|c|c|c|c|c|c|c|}
\hline \multirow[t]{2}{*}{$\begin{array}{l}\text { Recurrence } \\
\text { intervals } \\
\text { (years) }\end{array}$} & & & age fl & cated & cons & & \\
\hline & 1 & 3 & 7 & 14 & 30 & 60 & 90 \\
\hline 2 & 2.7 & 2.8 & 2.9 & 3.1 & 3.3 & 3.8 & 4.2 \\
\hline 5 & 1.9 & 2.0 & 2.1 & 2.2 & 2.5 & 2.9 & 3.3 \\
\hline 10 & 1.5 & 1.6 & 1.7 & 1.8 & 2.1 & 2.5 & 2.9 \\
\hline 20 & 1.2 & 1.3 & 1.4 & 1.5 & 1.8 & 2.2 & 2.6 \\
\hline
\end{tabular}

\section{DURATION OF DAILY FLOW}

Flow equaled or exceeded for indicated percentage of time

(cubic feet per second)

\begin{tabular}{ccccccc}
\hline 5 & 10 & 25 & 50 & 75 & 90 & 95 \\
\hline 12 & 9.1 & 6.4 & 4.9 & 3.9 & 3.0 & 2.6 \\
\hline
\end{tabular}


STATION NAME AND NUMBER.--02197310 Upper Three Runs above Road C at Savannah River Site, SC

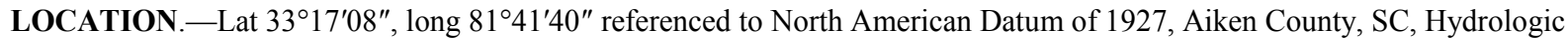
Unit 03060106, on right bank, $100 \mathrm{ft}$ upstream of SRS Road C, 2.0 mi east of SRS Road 2, at Savannah River Site.

DRAINAGE AREA. $-176 \mathrm{mi}^{2}$

PERIOD OF RECORD.- June 1974 to January 1998, December 1998 to September 2002

PERIOD OF ANALYSIS._-April 1975 to March 1997, April 1999 to March 2002

NUMBER OF CLIMATE YEARS IN FREQUENCY ANALYSIS. - 25

REMARKS.-

\section{MAGNITUDE AND FREQUENCY OF ANNUAL FLOWS}

\begin{tabular}{|c|c|c|c|c|c|c|c|}
\hline \multirow[t]{2}{*}{$\begin{array}{l}\text { Recurrence } \\
\text { intervals } \\
\text { (years) }\end{array}$} & & & age $\mathrm{fl}$ & icated & f cons & & \\
\hline & 1 & 3 & 7 & 14 & 30 & 60 & 90 \\
\hline 2 & 125 & 127 & 130 & 134 & 143 & 152 & 161 \\
\hline 5 & 104 & 106 & 109 & 113 & 120 & 129 & 137 \\
\hline 10 & 95 & 96 & 99 & 103 & 110 & 119 & 127 \\
\hline 20 & 87 & 88 & 91 & 95 & 101 & 111 & 119 \\
\hline 30 & 83 & 84 & 87 & 91 & 97 & 107 & 115 \\
\hline
\end{tabular}

\section{DURATION OF DAILY FLOW}

Flow equaled or exceeded for indicated percentage of time

(cubic feet per second)

\begin{tabular}{ccccccc}
\hline 5 & 10 & 25 & 50 & 75 & 90 & 95 \\
\hline 368 & 297 & 225 & 184 & 152 & 128 & 115 \\
\hline
\end{tabular}


STATION NAME AND NUMBER.--02197315 Upper Three Runs at Road A at Savannah River Site, SC

LOCATION.-Lat $33^{\circ} 14^{\prime} 20^{\prime \prime}$, long 81 $44^{\prime} 42^{\prime \prime}$ referenced to North American Datum of 1927, Aiken County, SC, Hydrologic Unit 03060106, near right bank, on downstream side of bridge at SRS Road A, 2.0 mi south of SRS Road 2, at Savannah River Site.

DRAINAGE AREA. $-203 \mathrm{mi}^{2}$

PERIOD OF RECORD.- - June 1974 to January 1998, October 1998 to September 2002

PERIOD OF ANALYSIS.-April 1975 to March 1997, April 1999 to March 2002

NUMBER OF CLIMATE YEARS IN FREQUENCY ANALYSIS. - 24

REMARKS.-

\section{MAGNITUDE AND FREQUENCY OF ANNUAL FLOWS}

\begin{tabular}{|c|c|c|c|c|c|c|c|}
\hline \multirow[t]{2}{*}{$\begin{array}{l}\text { Recurrence } \\
\text { intervals } \\
\text { (years) }\end{array}$} & & & age fl & icated & f cons & & \\
\hline & 1 & 3 & 7 & 14 & 30 & 60 & 90 \\
\hline 2 & 133 & 135 & 139 & 146 & 158 & 170 & 182 \\
\hline 5 & 108 & 110 & 114 & 118 & 130 & 140 & 150 \\
\hline 10 & 96 & 98 & 101 & 105 & 116 & 127 & 136 \\
\hline 20 & 87 & 89 & 92 & 95 & 106 & 116 & 124 \\
\hline 30 & 83 & 84 & 87 & 90 & 101 & 111 & 118 \\
\hline
\end{tabular}

\section{DURATION OF DAILY FLOW}

Flow equaled or exceeded for indicated percentage of time

(cubic feet per second)

\begin{tabular}{ccccccc}
\hline 5 & 10 & 25 & 50 & 75 & 90 & 95 \\
\hline 427 & 355 & 269 & 214 & 172 & 138 & 122 \\
\hline
\end{tabular}


STATION NAME AND NUMBER.-02197342 Site No. 7 at Savannah River Site, SC

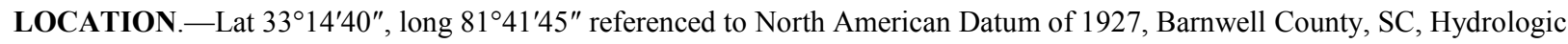
Unit 03060106, on right upstream end of concrete culvert pipe on Four Mile Creek at SRS Road A-7, 1.0 mi southwest of Area C, at Savannah River Site.

DRAINAGE AREA. $-12.5 \mathrm{mi}^{2}$

PERIOD OF RECORD.-October 1972 to September 2002

PERIOD OF ANALYSIS.-April 1973 to March 2002

NUMBER OF CLIMATE YEARS IN FREQUENCY ANALYSIS. -25

REMARKS.-Flow regulated by Savannah River Site operations.

\section{MAGNITUDE AND FREQUENCY OF ANNUAL FLOWS}

\begin{tabular}{|c|c|c|c|c|c|c|c|}
\hline \multirow[t]{2}{*}{$\begin{array}{l}\text { Recurrence } \\
\text { intervals } \\
\text { (years) }\end{array}$} & & & age $f$ & icate & f con & & \\
\hline & 1 & 3 & 7 & 14 & 30 & 60 & 90 \\
\hline 2 & 5.7 & 5.9 & 6.4 & 6.9 & 7.8 & 8.8 & 9.8 \\
\hline 5 & 4.3 & 4.6 & 4.9 & 5.3 & 6.1 & 6.9 & 7.9 \\
\hline 10 & 3.7 & 3.9 & 4.2 & 4.5 & 5.3 & 6.0 & 6.9 \\
\hline 20 & 3.2 & 3.4 & 3.7 & 3.9 & 4.7 & 5.4 & 6.3 \\
\hline 30 & 2.9 & 3.1 & 3.4 & 3.7 & 4.4 & 5.0 & 5.9 \\
\hline
\end{tabular}

\section{DURATION OF DAILY FLOW}

Flow equaled or exceeded for indicated percentage of time

(cubic feet per second)

\begin{tabular}{ccccccc}
\hline 5 & 10 & 25 & 50 & 75 & 90 & 95 \\
\hline 41 & 28 & 18 & 13 & 9.2 & 6.9 & 5.8 \\
\hline
\end{tabular}


STATION NAME AND NUMBER.—02197344 Four Mile Creek at Road A-12.2 at Savannah River Site, SC

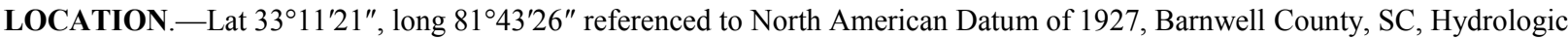
Unit 03060106, on left downstream side of bridge on SRS Road A-12.2, $500 \mathrm{ft}$ northwest of SRS Road A-13, 1.0 mi southeast of Area D, at Savannah River Site.

DRAINAGE AREA. $-22.0 \mathrm{mi}^{2}$

PERIOD OF RECORD.-November 1976 to September 2002

PERIOD OF ANALYSIS.-April 1986 to March 2002

NUMBER OF CLIMATE YEARS IN FREQUENCY ANALYSIS. - 16

REMARKS.-Flow regulated by Savannah River Site operations. Based on quality assurance and quality control assessments, the regulation patterns changed after climate year 1986. Therefore, only the record after April 1986 was used in the analysis.

\section{MAGNITUDE AND FREQUENCY OF ANNUAL FLOWS}

\begin{tabular}{|c|c|c|c|c|c|c|c|}
\hline \multirow[t]{2}{*}{$\begin{array}{l}\text { Recurrence } \\
\text { intervals } \\
\text { (years) }\end{array}$} & & & age fl & catec & cons & & \\
\hline & 1 & 3 & 7 & 14 & 30 & 60 & 90 \\
\hline 2 & 12 & 12 & 13 & 14 & 16 & 18 & 20 \\
\hline 5 & 8.6 & 8.9 & 9.6 & 10 & 12 & 13 & 15 \\
\hline 10 & 7.2 & 7.5 & 8.2 & 8.7 & 9.8 & 11 & 13 \\
\hline 20 & 6.3 & 6.5 & 7.3 & 7.7 & 8.5 & 10 & 11 \\
\hline
\end{tabular}

\section{DURATION OF DAILY FLOW}

Flow equaled or exceeded for indicated percentage of time

(cubic feet per second)

\begin{tabular}{lllcccc}
\hline 5 & 10 & 25 & 50 & 75 & 90 & 95 \\
\hline 73 & 50 & 33 & 22 & 16 & 12 & 10 \\
\hline
\end{tabular}


STATION NAME AND NUMBER.—02197348 Pen Branch at Road A-13.2 at Savannah River Site, SC

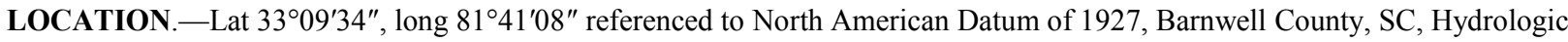
Unit 03060106, on right downstream side of bridge on SRS Road A-13.2, $700 \mathrm{ft}$ downstream from Seaboard Coastline Railroad bridge, $800 \mathrm{ft}$ west of intersection of SRS Roads A-17 and A-17.1, at Savannah River Site.

DRAINAGE AREA. $-21.2 \mathrm{mi}^{2}$

PERIOD OF RECORD.- - November 1976 to September 2002

PERIOD OF ANALYSIS.-April 1988 to March 2002

NUMBER OF CLIMATE YEARS IN FREQUENCY ANALYSIS. -14

REMARKS.-Flow regulated by Savannah River Site operations. Based on quality assurance and quality control assessments, the regulation patterns changed after climate year 1988. Therefore, only the record after April 1988 was used in the analysis.

\section{MAGNITUDE AND FREQUENCY OF ANNUAL FLOWS}

\begin{tabular}{|c|c|c|c|c|c|c|c|}
\hline \multirow[t]{2}{*}{$\begin{array}{l}\text { Recurrence } \\
\text { intervals } \\
\text { (years) }\end{array}$} & \multicolumn{7}{|c|}{ (cubic feet per second) } \\
\hline & 1 & 3 & 7 & 14 & 30 & 60 & 90 \\
\hline 2 & 14 & 15 & 15 & 17 & 18 & 22 & 24 \\
\hline 5 & 6.8 & 7.1 & 7.6 & 8.0 & 8.8 & 11 & 12 \\
\hline 10 & 4.5 & 4.7 & 5.0 & 5.3 & 5.9 & 7.6 & 8.4 \\
\hline 20 & 3.1 & 3.2 & 3.5 & 3.7 & 4.1 & 5.6 & 6.2 \\
\hline
\end{tabular}

\section{DURATION OF DAILY FLOW}

Flow equaled or exceeded for indicated percentage of time

(cubic feet per second)

\begin{tabular}{ccccccc}
\hline 5 & 10 & 25 & 50 & 75 & 90 & 95 \\
\hline 206 & 115 & 59 & 37 & 14 & 8.2 & 6.8 \\
\hline
\end{tabular}


STATION NAME AND NUMBER.—021973565 Steel Creek at Road A at Savannah River Site, SC

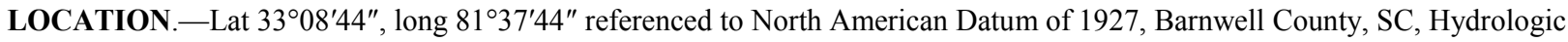
Unit 03060106, on right downstream side of bridge on SRS Road A, $160 \mathrm{ft}$ downstream from Meyers Branch, at Savannah River Site.

DRAINAGE AREA.- - Undetermined

PERIOD OF RECORD.-March 1985 to September 2002

PERIOD OF ANALYSIS.-April 1985 to March 2002

NUMBER OF CLIMATE YEARS IN FREQUENCY ANALYSIS. - 17

REMARKS.-Flow regulated by Savannah River Site operations. Based on quality assurance and quality control assessments indicating numerous changes in regulation patterns, only exceedance percentiles of annual 7-day minimum flows and duration of daily flow were computed.

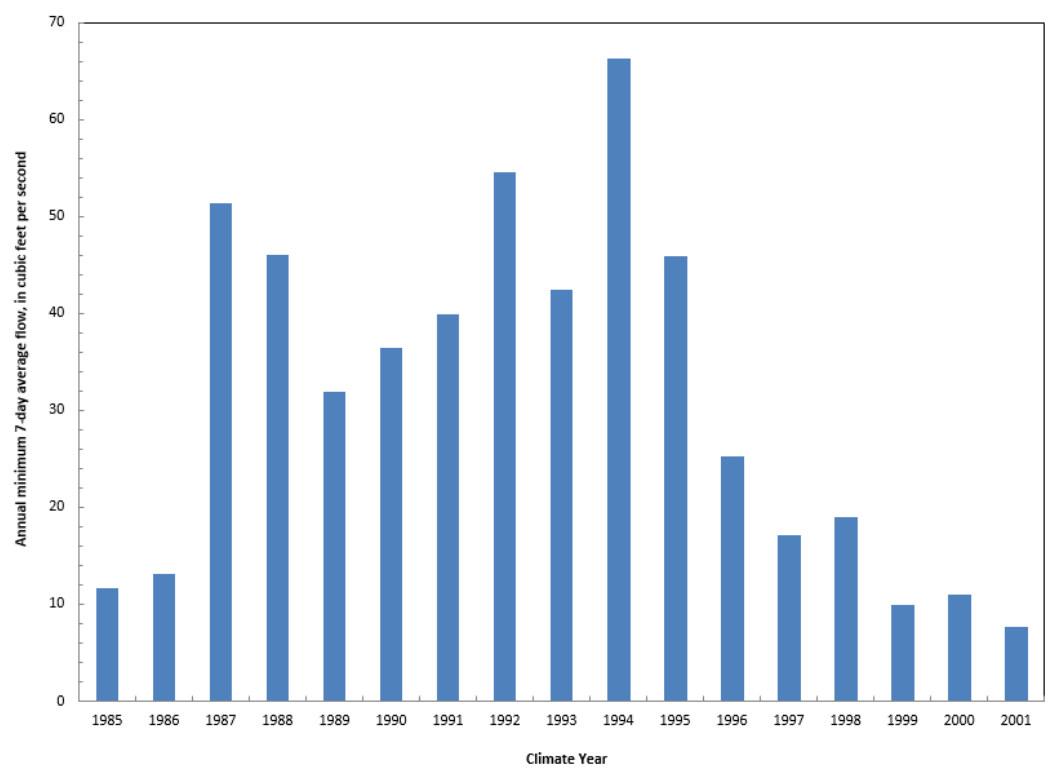

EXCEEDANCE PERCENTILES OF ANNUAL 7-DAY MINIMUM FLOWS

Annual 7-day minimum flow exceeded for indicated percentiles (cubic feet per second)

\begin{tabular}{l|l|l|l|l|l|l|l|l}
\hline 10 & 20 & 30 & 40 & 50 & 60 & 70 & 80 & 90 \\
\hline 57 & 48 & 44 & 39 & 32 & 20 & 15 & 11 & 9.4 \\
\hline
\end{tabular}

DURATION OF DAILY FLOW

Flow equaled or exceeded for indicated percentage of time (cubic feet per second)

\begin{tabular}{lllllll}
\hline 5 & 10 & 25 & 50 & 75 & 90 & 95 \\
\hline 387 & 332 & 127 & 73 & 28 & 15 & 12 \\
\hline
\end{tabular}


STATION NAME AND NUMBER.—02197380 Lower Three Runs below Par Pond at Savannah River Site, SC

LOCATION.-Lat $33^{\circ} 14^{\prime} 07^{\prime \prime}$, long 81 $31^{\prime} 00^{\prime \prime}$ referenced to North American Datum of 1927, Barnwell County, SC, Hydrologic Unit 03060106, on right upstream side of west bound bridge on SRS Road B, $200 \mathrm{ft}$ downstream of spillway culvert below Par Pond, at Savannah River Site.

DRAINAGE AREA. $-34.9 \mathrm{mi}^{2}$

PERIOD OF RECORD.-May 1974 to September 1982, February 1987 to September 2002

PERIOD OF ANALYSIS._-April 1975 to March 1982, April 1987 to March 2002

NUMBER OF CLIMATE YEARS IN FREQUENCY ANALYSIS. - 21

REMARKS.-Flow regulated by Savannah River Site operations.

\section{MAGNITUDE AND FREQUENCY OF ANNUAL FLOWS}

\begin{tabular}{|c|c|c|c|c|c|c|c|}
\hline \multirow[t]{2}{*}{$\begin{array}{l}\text { Recurrence } \\
\text { intervals } \\
\text { (years) }\end{array}$} & \multicolumn{7}{|c|}{ (cubic feet per second) } \\
\hline & 1 & 3 & 7 & 14 & 30 & 60 & 90 \\
\hline 2 & 4.9 & 5.3 & 5.8 & 7.0 & 8.8 & 12 & 15 \\
\hline 5 & 2.0 & 2.3 & 2.5 & 3.0 & 3.8 & 6.0 & 8.9 \\
\hline 10 & 1.2 & 1.4 & 1.6 & 1.9 & 2.3 & 4.1 & 7.1 \\
\hline 20 & 0.82 & 0.97 & 1.1 & 1.3 & 1.5 & 3.0 & 5.9 \\
\hline 30 & 0.65 & 0.79 & 0.90 & 1.0 & 1.2 & 2.6 & 5.4 \\
\hline
\end{tabular}

\section{DURATION OF DAILY FLOW}

Flow equaled or exceeded for indicated percentage of time

(cubic feet per second)

\begin{tabular}{ccccccc}
\hline 5 & 10 & 25 & 50 & 75 & 90 & 95 \\
\hline 76 & 63 & 46 & 28 & 13 & 8.6 & 5.5 \\
\hline
\end{tabular}


STATION NAME AND NUMBER.—02197400 Lower Three Runs near Snelling, SC

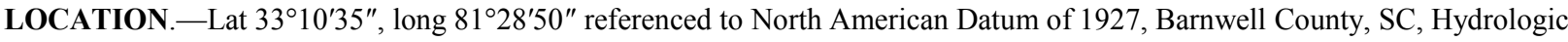
Unit 03060106, near left bank at upstream side of bridge on State road 20, 1.0 mi upstream from Patterson Branch and $4.7 \mathrm{mi}$ south of Snelling.

DRAINAGE AREA. $-59.3 \mathrm{mi}^{2}$

PERIOD OF RECORD.-March 1974 to September 2002

PERIOD OF ANALYSIS.-April 1974 to March 2002

NUMBER OF CLIMATE YEARS IN FREQUENCY ANALYSIS. - 26

REMARKS.-Flow regulated by Savannah River Site operations.

\section{MAGNITUDE AND FREQUENCY OF ANNUAL FLOWS}

\begin{tabular}{|c|c|c|c|c|c|c|c|}
\hline \multirow[t]{2}{*}{$\begin{array}{l}\text { Recurrence } \\
\text { intervals } \\
\text { (years) }\end{array}$} & & & ge $f$ & cate & con & & \\
\hline & 1 & 3 & 7 & 14 & 30 & 60 & 90 \\
\hline 2 & 23 & 24 & 25 & 27 & 31 & 36 & 42 \\
\hline 5 & 17 & 17 & 18 & 20 & 22 & 26 & 30 \\
\hline 10 & 14 & 15 & 16 & 17 & 19 & 22 & 25 \\
\hline 20 & 13 & 13 & 14 & 15 & 17 & 19 & 22 \\
\hline 30 & 12 & 13 & 13 & 14 & 16 & 18 & 20 \\
\hline
\end{tabular}

\section{DURATION OF DAILY FLOW}

Flow equaled or exceeded for indicated percentage of time

(cubic feet per second)

\begin{tabular}{ccccccc}
\hline 5 & 10 & 25 & 50 & 75 & 90 & 95 \\
\hline 181 & 144 & 96 & 65 & 38 & 27 & 23 \\
\hline
\end{tabular}


STATION NAME AND NUMBER.--02197500 Savannah River at Burtons Ferry Bridge near Millhaven, GA

LOCATION.-Lat 32 $56^{\prime 2} 20^{\prime \prime}$, long 81 $30^{\prime} 10^{\prime \prime}$ referenced to North American Datum of 1927, Screven County, GA, Hydrologic Unit 03060106, on right bank $500 \mathrm{ft}$ downstream from U.S. Highway 301 bridge, 2.0 mi downstream from Rocky Creek, $9.0 \mathrm{mi}$ east of Millhaven, and at mile 118.7 .

DRAINAGE AREA. $-8,650 \mathrm{mi}^{2}$

PERIOD OF RECORD.- October 1939 to September 1970, October 1982 to October 2003, October 2004 to March 2014

PERIOD OF ANALYSIS.-April 1986 to March 2003, April 2005 to March 2014

NUMBER OF CLIMATE YEARS IN FREQUENCY ANALYSIS. - 26

REMARKS.-Regulated since about 1954 by J.Strom Thurmond Lake, 1962 by Lake Hartwell, and 1985 by Richard B. Russell Lake. The low-flow statistics represent the most recent period of relatively stable regulation.

MAGNITUDE AND FREQUENCY OF ANNUAL FLOWS

\begin{tabular}{|c|c|c|c|c|c|c|c|}
\hline \multirow[t]{2}{*}{$\begin{array}{l}\text { Recurrence } \\
\text { intervals } \\
\text { (years) }\end{array}$} & & & rage flo & licated & f conse & & \\
\hline & 1 & 3 & 7 & 14 & 30 & 60 & 90 \\
\hline 2 & 4,470 & 4,550 & 4,690 & 4,850 & 5,080 & 5,350 & 5,590 \\
\hline 5 & 4,100 & 4,140 & 4,220 & 4,330 & 4,460 & 4,620 & 4,740 \\
\hline 10 & 3,930 & 3,960 & 4,020 & 4,090 & 4,180 & 4,290 & 4,370 \\
\hline 20 & 3,810 & 3,820 & 3,860 & 3,920 & 3,970 & 4,040 & 4,080 \\
\hline 30 & 3,760 & 3,760 & 3,800 & 3,840 & 3,860 & 3,920 & 3,950 \\
\hline
\end{tabular}

\section{DURATION OF DAILY FLOW}

Flow equaled or exceeded for indicated percentage of time

(cubic feet per second)

\begin{tabular}{ccccccc}
\hline 5 & 10 & 25 & 50 & 75 & 90 & 95 \\
\hline 25,400 & 18,300 & 9,660 & 6,480 & 5,200 & 4,640 & 4,430 \\
\end{tabular}


STATION NAME AND NUMBER.--02198500 Savannah River near Clyo, GA

LOCATION.—Lat 32³1'41", long 81 $16^{\prime} 08^{\prime \prime}$ referenced to North American Datum of 1927, Effingham County, GA, Hydrologic Unit 03060109, at Georgia-South Carolina State line, on downstream side of State Highway 119 bridge, 3.0 mi north of Clyo, and at river mile 61.4 .

DRAINAGE AREA. $-9,850 \mathrm{mi}^{2}$

PERIOD OF RECORD.-October 1929 to September 1933, October 1937 to March 2014

PERIOD OF ANALYSIS.-April 1986 to March 2014

NUMBER OF CLIMATE YEARS IN FREQUENCY ANALYSIS. —-28

REMARKS.-Regulated since about 1954 by J.Strom Thurmond Lake, 1962 by Lake Hartwell, and 1985 by Richard B. Russell Lake. The low-flow statistics represent the most recent period of relatively stable regulation.

\section{MAGNITUDE AND FREQUENCY OF ANNUAL FLOWS}

\begin{tabular}{|c|c|c|c|c|c|c|c|}
\hline \multirow[t]{2}{*}{$\begin{array}{l}\text { Recurrence } \\
\text { intervals } \\
\text { (years) }\end{array}$} & & & rage flo & dicated & f conse & & \\
\hline & 1 & 3 & 7 & 14 & 30 & 60 & 90 \\
\hline 2 & 5,070 & 5,120 & 5,210 & 5,340 & 5,550 & 5,840 & 6,100 \\
\hline 5 & 4,530 & 4,560 & 4,620 & 4,700 & 4,810 & 4,950 & 5,070 \\
\hline 10 & 4,270 & 4,300 & 4,310 & 4,410 & 4,480 & 4,550 & 4,610 \\
\hline 20 & 4,070 & 4,090 & 4,130 & 4,190 & 4,230 & 4,250 & 4,260 \\
\hline 30 & 3,970 & 4,000 & 4,030 & 4,090 & 4,100 & 4,100 & 4,100 \\
\hline
\end{tabular}

\section{DURATION OF DAILY FLOW}

Flow equaled or exceeded for indicated percentage of time

(cubic feet per second)

\begin{tabular}{ccccccc}
\hline 5 & 10 & 25 & 50 & 75 & 90 & 95 \\
& & & & & & \\
\hline 27,800 & 19,000 & 11,100 & 7,390 & 5,710 & 4,960 & 4,730 \\
\hline
\end{tabular}


Manuscript was approved on June 16, 2016

For further information about this publication contact:

Director

U.S. Geological Survey

South Atlantic Water Science Center

720 Gracern Road

Columbia, SC 29210

http://www.usgs.gov/water/southatlantic/

Prepared by the Reston Publishing Service Center 


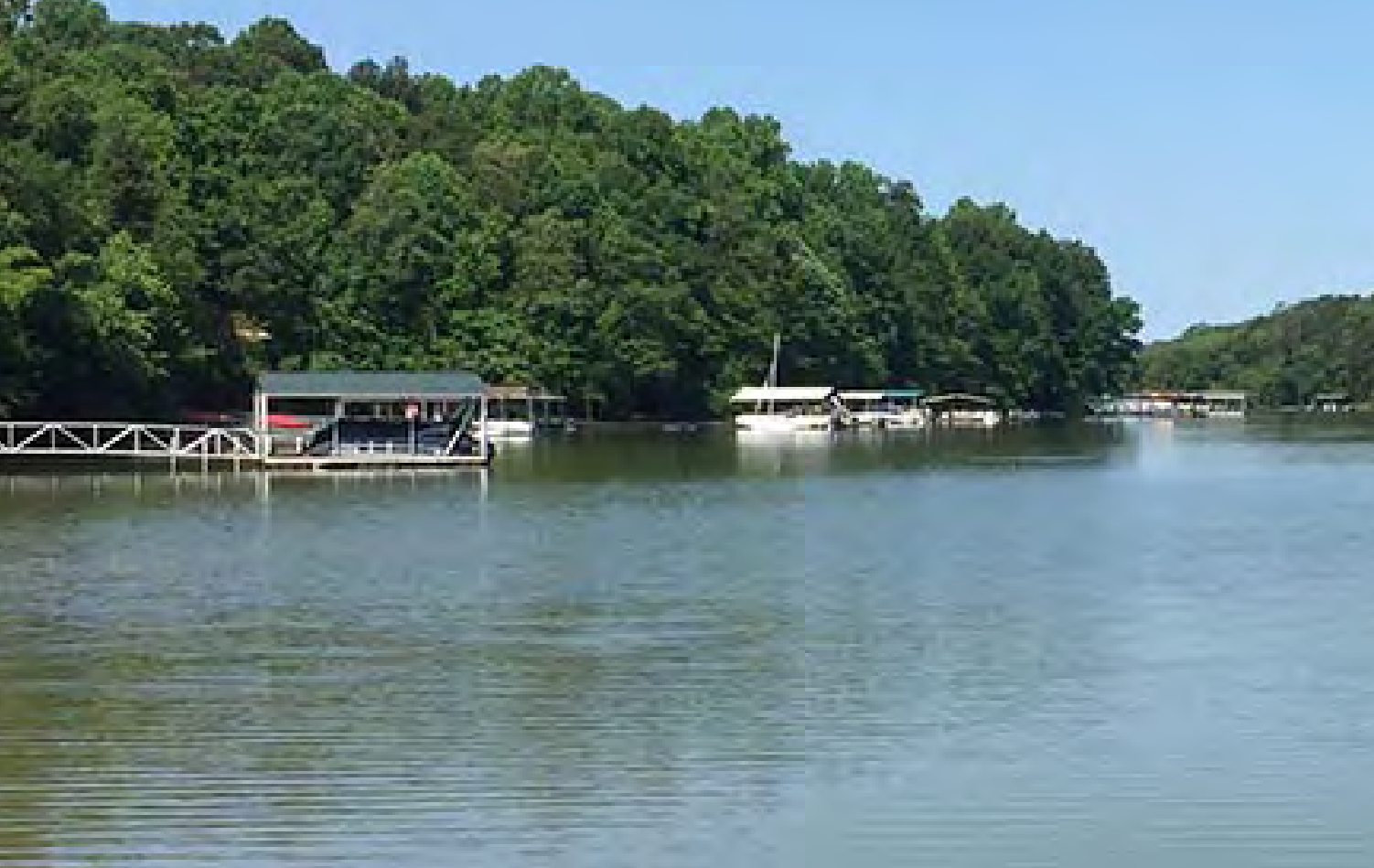

